\title{
PAUSA PARA PINTURA
}

\author{
Tese apresentada ao Programa de Pós Graduação em Artes Visuais \\ Escola de Comunicações e Artes da Universidade de São Paulo \\ para obtenção do título de Doutora em Artes Visuais
}

Área de concentração: Poéticas Visuais

Orientador: Prof. Dr. Geraldo Souza Dias 
BANCA EXAMINADORA 


\section{agradecimentos}

Ao meu orientador Geraldo Souza Dias, por toda atenção dedicada durante todos esses anos. Ao Marco Giannotti e Paulo Pasta pelos caminhos apontados. Aos meus pais Nelson dos Santos Pereira e Marina Junqueira Pereira por estarem juntos de mim. Ao meu irmão, Nelson dos Santos Pereira Junior pela grande força de sempre.

E em especial ao meu marido, Paulo Gil que foi interlocutor, autor de imagens de que me apropriei para realização de muitas pinturas, responsável pelo projeto visual deste livro e principalmente pelo seu carinho, paciência e compreensão durante todo processo. 


\section{RESUMO}

Pausar, em "Pausa para Pintura", se refere tanto aos momentos de suspensão que minhas pinturas sugerem, quanto à ação de pausar uma cena de vídeo para posteriormente servir de "modelo" para a pintura. Ao longo dos últimos quatro anos, pequenos ensaios que tratam do meu processo de trabalho e uma série de pinturas com o tema da cidade e seus habitantes foram realizados. Os conceitos de absorção, fluidez, deformação, transformação, transitoriedade, aproximação, distanciamento, movimento e imobilidade, permeiam o texto e a pintura. A concretização desses pensamentos se dá através de uma exposição dos trabalhos desenvolvidos no período.

Palavras chave: pausa; pintura; relação video-pintura; mito de Marsias

\section{ABSTRACT}

The word pause in "Pause for Painting" refers to the moments of suspension that my paintings suggest as well as to the action of pausing a video scene that later on will serve as "model" for the painting. Over the last four years, I realized short essays dealing with my working process and a series of paintings on the theme of the city and its dwellers. Concepts, such as absorption, fluidity, deformation, transformation, transit, approaching, distancing, motion and stillness pass through the text and the painting. The embodiment of these thoughts occurs by means of an exhibition of the works done in the period.

Keywords: pause; painting; relation video-painting; Mith of Marsyas 


\section{SUMÁRIO}

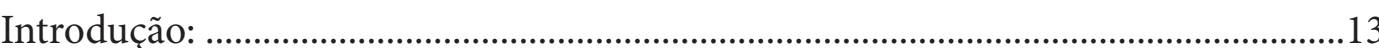

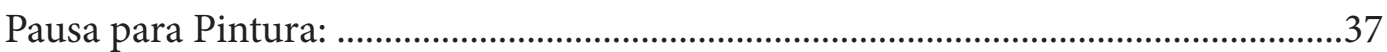

Pele e Entranhas: uma Conclusão?: ...............................................................................69

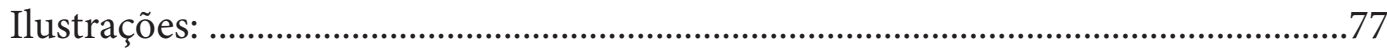

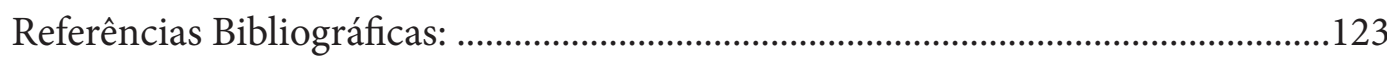




\section{INTRODUÇÃO}



O objeto desta tese é o conjunto de pinturas realizadas a partir de 2010 e apresentadas aqui em forma livro.

Os fundamentos da escrita encontram-se na experiência do fazer e nas conclusões tiradas pela observação das obras já prontas.

Levo em conta para este estudo minha trajetória, a história da arte e obras dos artistas e teóricos que tenho como referência. Como conclusão e parte fundamental do trabalho, a exposição que é a síntese destes últimos quatro anos.

Pode parecer paradoxal introduzir um texto sobre pintura com palavras de um artista que ficou conhecido por "negá-la": Marcel Duchamp. No entanto, não haveria razão para não citá-lo uma vez que sua crença na arte supera qualquer tentativa de classificar e qualificar as linguagens artísticas.

\section{Necessidade de crer}

Octavio Paz em Castelo da Pureza diz ser uma estupidez pensar que Duchamp é um "niilista vulgar". Sua não arte existiu justamente porque ele acreditava na arte. "Crer" significaria não um ato de sabedoria, mas um estado do ser. Nas palavras do próprio artista:

"Gosto da palavra crer. Em geral, quando alguém diz eu sei, não sabe, acredita. Creio que a Arte é a única forma de atividade pela qual o homem se manifesta como indivíduo. Só por ela pode superar o estado animal, porque a Arte desemboca em regiões que nem o tempo nem o espaço dominam. Viver é crer - ao menos é isto o que eu creio."

Esse pensamento nos faz constatar o quanto o trabalho do artista está embebido de questões humanas, das incertezas da vida e, sobretudo, da contradição que "é o que distingue os homens dos anjos, dos animais e das máquinas". ${ }^{2}$

Vejo a pintura também como um ato de fé. Pintar remete a um "eterno recomeçar" que só vale a pena quando queremos que ele siga em frente: a próxima pintura será sempre

1 DUCHAMP, Marcel apud PAZ, Otávio. Marcel Duchamp ou o Castelo da Pureza,Perspectiva, 1990, p.58 
melhor que a anterior, senão nem começaríamos. E assim vamos criando uma poética coerente com a própria vida.

Pela sua duração ou sucessão de hábitos é que também conseguimos atingir uma unidade no trabalho. Como a trama da pintura, existe a trama da duração que se forma colocando-se um instante atrás do outro.

Muitas vezes não é pelo conjunto que tomamos um novo rumo, mas pela última obra, aquela que queremos olhar por mais tempo, ou porque descobrimos alguma coisa peculiar ou porque nos incomoda.

Questões sempre surgem no processo: e se a próxima pintura não ficar melhor? É possível fazer sempre melhor? O que significa “melhor”?

De um ponto de vista racional, não haveria desejo que persistisse se fizéssemos algo tão despropositado. Se existe uma obsessão que só é saciada nos momentos do "fazer", então por que não fazer?

O que muda com essa suposição é que mesmo se a ação não fizer sentido existe um estado emocional e mental quando nos entregamos a um trabalho que compensa pelo ato em si.

Como base para a minha pintura utilizo fotografias e frames de vídeo de diversas fontes: internet, imagens de tv, fotos de família, de viagem, fotografias autorais e, atualmente, os meus próprios vídeos, em que filmo minhas caminhadas e viagens de metrô em São Paulo e em Porto Alegre. Sempre que possível mantenho a complexidade da imagem inicial. Quero representar o que é público e genérico de uma maneira que isso fique íntimo e específico.

Acredito na validade da pintura porque ela está atrelada a minha vida. As ações que realizo para desembocar nela atestam a fé nesta linguagem.

Se meu trabalho como artista se realizasse só nas andanças pelas ruas e subterrâneos da cidade ou se considerasse os vídeos um trabalho final, talvez não pudesse "provar" 
essa minha crença. E isso se explica porque acredito que minhas pinturas são "melhores" que meus vídeos ou, pelo menos, me fazem mais sentido.

\section{Antecedentes}

Desde a infância tenho um envolvimento grande com o desenho e a pintura. Era uma espécie de brincar de boneca: desenhava e pintava a figura humana para depois recortar e transformar em personagens das histórias que contava para mim mesma.

Um pouco mais tarde, na adolescência, a história acontecia só no papel. O processo era: desenhar com lápis grafite e com a borracha ir apagando e refazendo partes, transformando os traços fisionômicos da figura de acordo com o desenrolar da história que seguia o curso natural: nascimento, vida e morte. De alguma maneira não predominava apenas o aspecto lúdico, já existia a necessidade de dar respostas às dúvidas e dores humanas que então apareciam.

Hoje a narrativa tem menos importância, o que não elimina sua existência mas, ao observar minha trajetória vejo que o envolvimento e a insistência de pintar coisas transformaram-se em uma explicitação da pintura figurativa.

Interessa-me o jogo que se cria entre o figurativo e o abstrato. Acredito que uma imagem que vem da realidade só tem qualidade quando a organização abstrata das formas funciona bem. Pode-se então dizer que de alguma maneira, toda pintura é abstrata.

Venho trabalhando com arte profissionalmente desde 1988, quando me formei em artes plásticas pela Escola de Comunicações e Artes da Universidade de São Paulo.

Um período marcante na minha trajetória ocorreu em 1994 quando residi por cinco anos na cidade de Sttutgart, na Alemanha e frequentei, por quatro semestres, a FKN (Freie Kunstakademie Nürtingen), uma faculdade privada de arte. 
Dois projetos realizados entre 1996 e 1998 e que se concretizaram em forma de exposição são a base da pintura que realizo e parte das minhas reflexões até hoje. Os pontos em comum são: relação entre pintura e espaço, o envolvimento com a questão da figura humana e a exploração de diferentes superfícies e tamanhos.

Págs. 21-23

\section{“Allianz-Aliança- Pintura e Seguro” (1997)}

Entre outubro de 96 e junho de 97, instalei mais ou menos 300 pinturas em óleo sobre papel, no tamanho 30 x 20 cm, em um espaço de escritório da seguradora Allianz. A ideia de mostrá-las no local de trabalho partiu primeiramente do fato das pinturas terem sido feitas em papel "tamanho ofício" e que, portanto, criavam uma relação de forma com os papéis utilizados para o trabalho de escritório. Por outro lado se distanciavam deste mundo dos negócios e dos ofícios pelos tipos de imagens, temas e maneiras de colocação nas paredes.

A discussão "seguro e arte" era o mote do projeto. As pinturas apresentavam em sua figuração objetos, pessoas, animais que de algum modo provocavam uma reflexão sobre $\mathrm{o}$ assunto.

A montagem reforçou esse paradoxo, na grande quantidade de pinturas e na maneira "caleidoscópica" de apresentar temas e técnicas diversas. Partiam de fotos de revistas, de desenhos de imaginação, de memória, da observação de objetos pessoais que se encontravam no ateliê, etc.

Quanto ao tipo de pincelada, cor e figuração notava-se em algumas de minhas pinturas, uma semelhança com o Neue Wilde, grupo de neo-expressionistas alemães. Um dos artistas que me interessava era Karl Horst Hödicke, com suas imagens sintéticas de figuras humanas e animais .

Págs. 24-27 “100 pinturas para... (Portraits)“ (1998)

Realizei um segundo projeto que tratou do gênero retrato. A exposição ocorreu num espaço público: o prédio da prefeitura da cidade de Nürtingen, ou mais especificamente em salas de trabalho de 10 funcionários deste lugar.

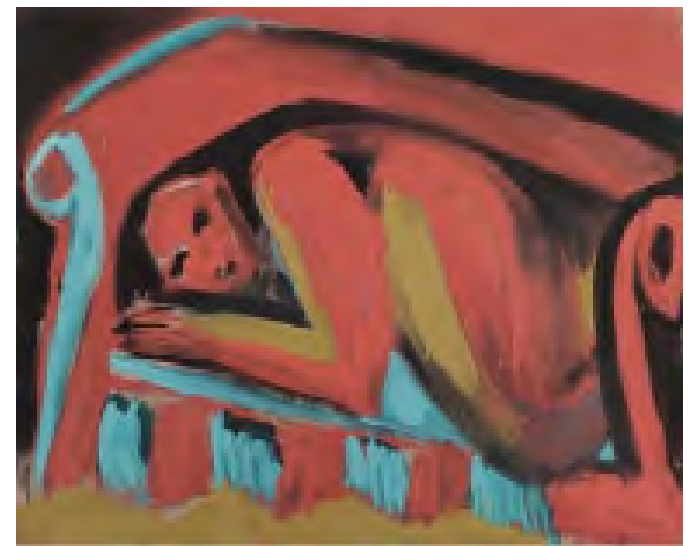

Karl Horst Hödicke, Elvira lying on the couch, 1987, óleo sobre tela, 155 x 190 cm

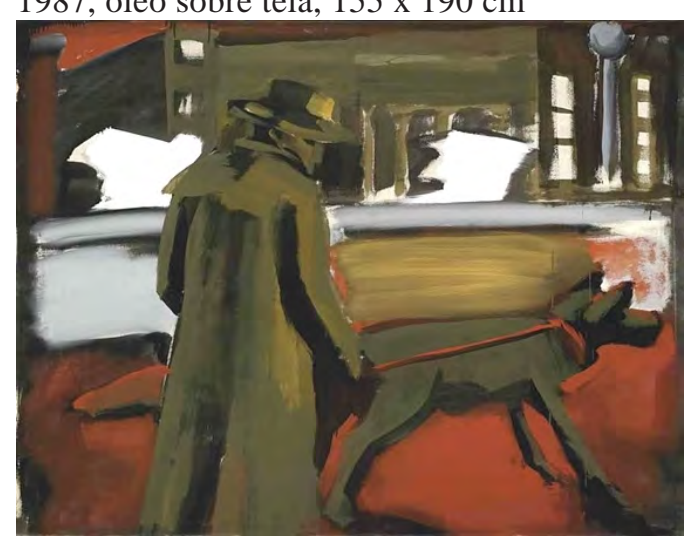

Karl Horst Hödicke, sem título,1976, óleo sobre tela, 145 x 190,5 cm 


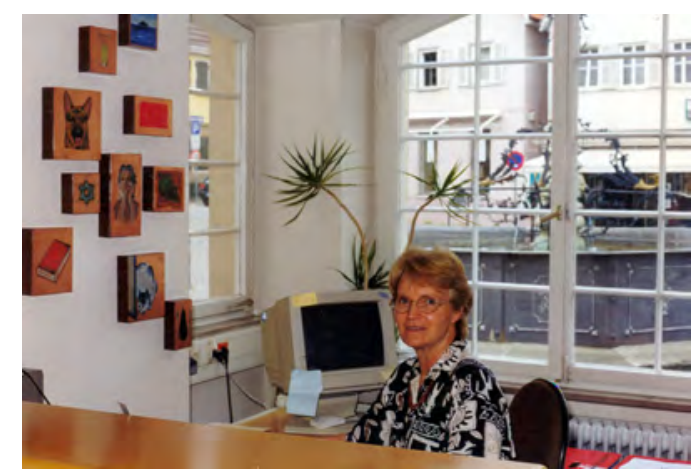

"100 pinturas para... (Portraits)“, Nürtingen, Alemanha, 1998. Detalhe.

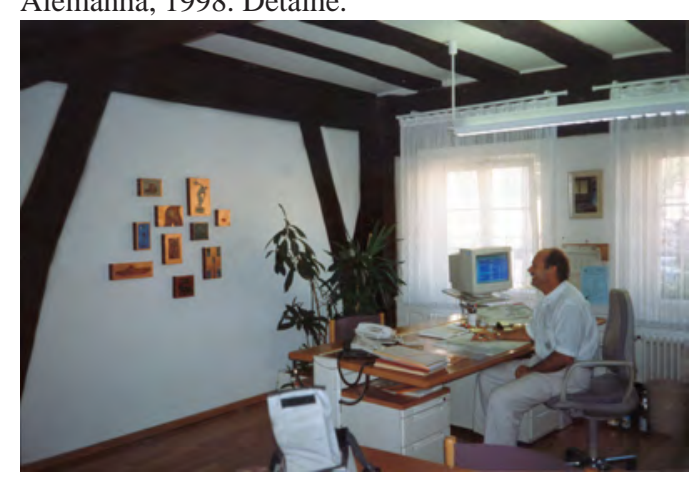

"100 pinturas para... (Portraits)“, Nürtingen, Alemanha, 1998. Detalhe.

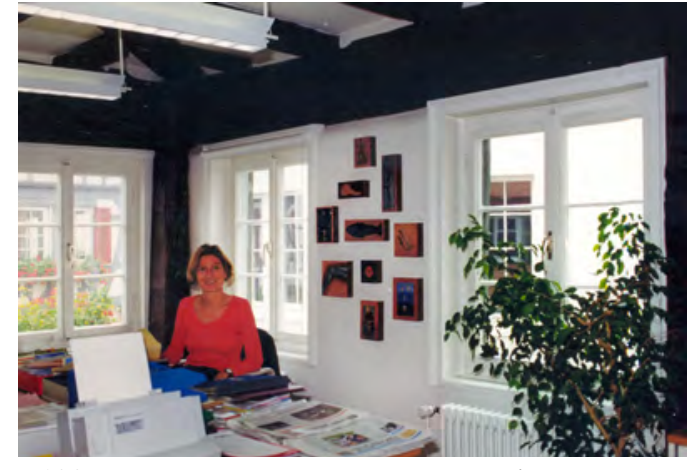

“100 pinturas para... (Portraits)“, Nürtingen, Alemanha, 1998. Detalhe.
A criação de um conjunto de pinturas para cada retratado foi inspirada nas pinturas fragmentadas do projeto anterior. Entre modelo e pintor o contato se deu não pelo olhar do artista com intenção de representar, mas através de um questionário aplicado previamente.

As questões suscitaram as preferências dos funcionários sobre os mais diversos temas da vida, referendadas no momento da conversa entre artista e modelo, motivando imagens que geraram 10 pequenas pinturas que agrupadas formavam o "retrato".

Havia uma proposta de "colagem" de gêneros pictóricos, por isso direcionei as perguntas para assuntos que levavam a essa exploração. E também experimentei um novo suporte: o cobre, com base em pesquisa sobre os miniaturistas holandeses do século XVI e XVII, que o escolhiam justamente pela lisura da superfície.

\section{“Paisagens Distantes” (2001-07)}

De retorno ao Brasil no final de 1999, comecei a pesquisa sobre a pintura a partir de imagens digitais.

Partindo de fotos de viagem que manipulava com programa de computador, "transferia" imagens para a tela. Foi o inicio da utilização de um projetor de slides como técnica de ampliação. De maneira incisiva, minha pintura passou a ter a fotografia como base.

De 2001 a 2007 realizei a série que intitulei "Paisagens Distantes", comprometida com a apresentação de um mundo observado através de muitos "filtros", manipulando imagens provenientes da internet.

A ideia de utilizar este processo no trabalho surgiu da vontade de fazer uma pintura baseada na apropriação de imagens com "ruídos eletrônicos", imagens com "defeito".

\section{“Verdades Inventadas” (2007-2009)}

Págs. 32-35

"Verdades inventadas: Pinturas de cenas" foi o título por mim escolhido para meu trabalho de mestrado, concluído em 2009, cujo elemento central foi um questionamento sobre a pintura que se iniciava não como a tela branca, mas com a tela já preenchida pela imagem projetada: uma reflexão sobre "o que" origina uma pintura.

Págs. 28-31

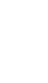


O motivo para uma nova pintura estava atrelado à necessidade de dar continuidade a uma "história", ou seja, criar um conjunto de obras com uma lógica interna específica. Isso não quer dizer que as pinturas individualmente fossem incompletas ou que não se sustentassem.

Não existia um tema predominante em uma série, mas uma configuração de atmosfera comum, criada ora por associação de cor ou forma, ora por elementos temáticos contrastantes que sugeriam dissonância no conjunto.

Os “ruídos eletrônicos” que me seduziam e me remetiam à pintura eram a constatação de que o mundo, a realidade, não é constante. Ela é desfocada, contêm grãos, falhas etc.

Uma das perguntas que levantei nesta pesquisa foi se minha pincelada gestual, a matéria densa sobre a superfície e a composição com cores vibrantes estariam buscando a "poltrona" de Matisse ou a tensão, a violência de um autêntico expressionista alemão.

Como resposta, acredito que almejo os elementos de ambos. 


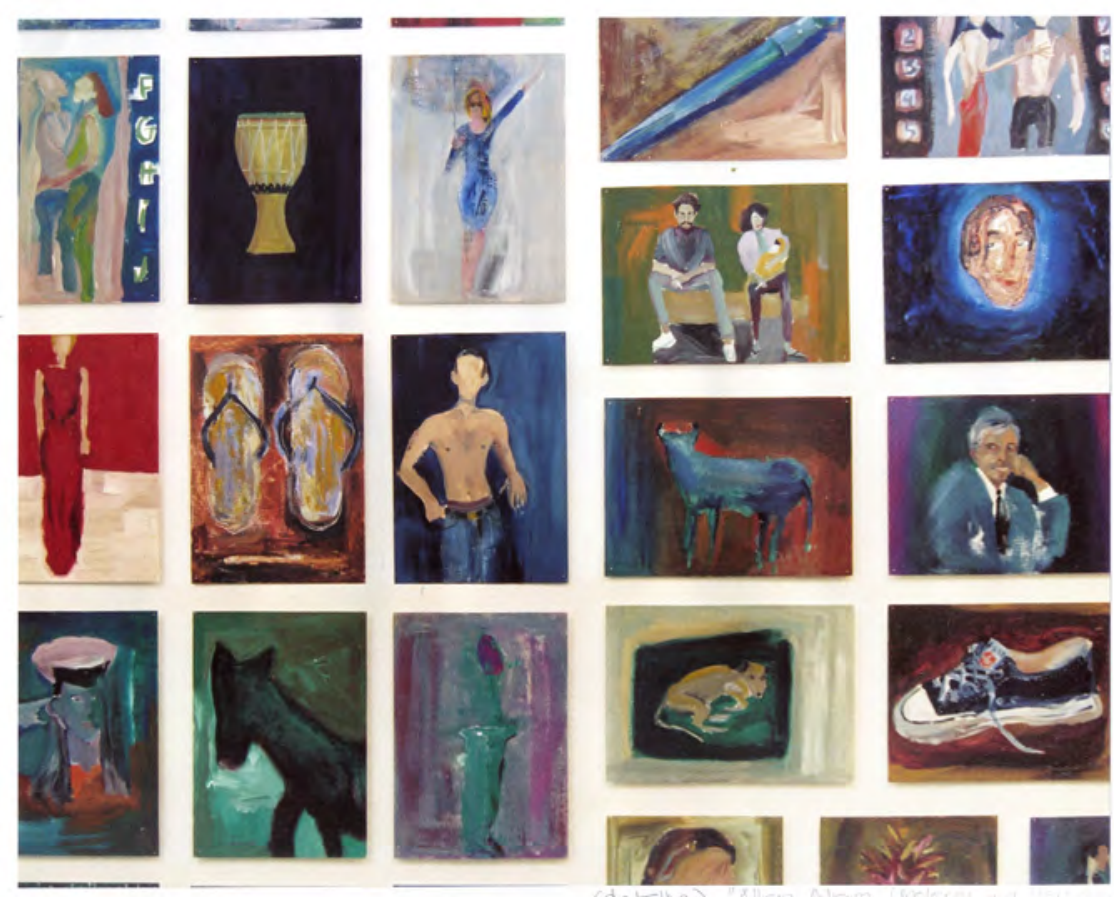

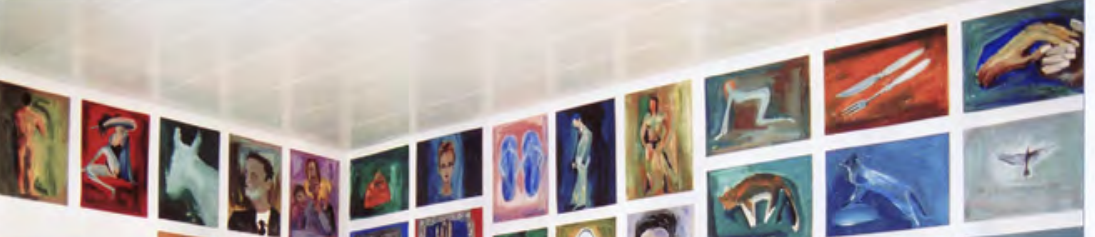

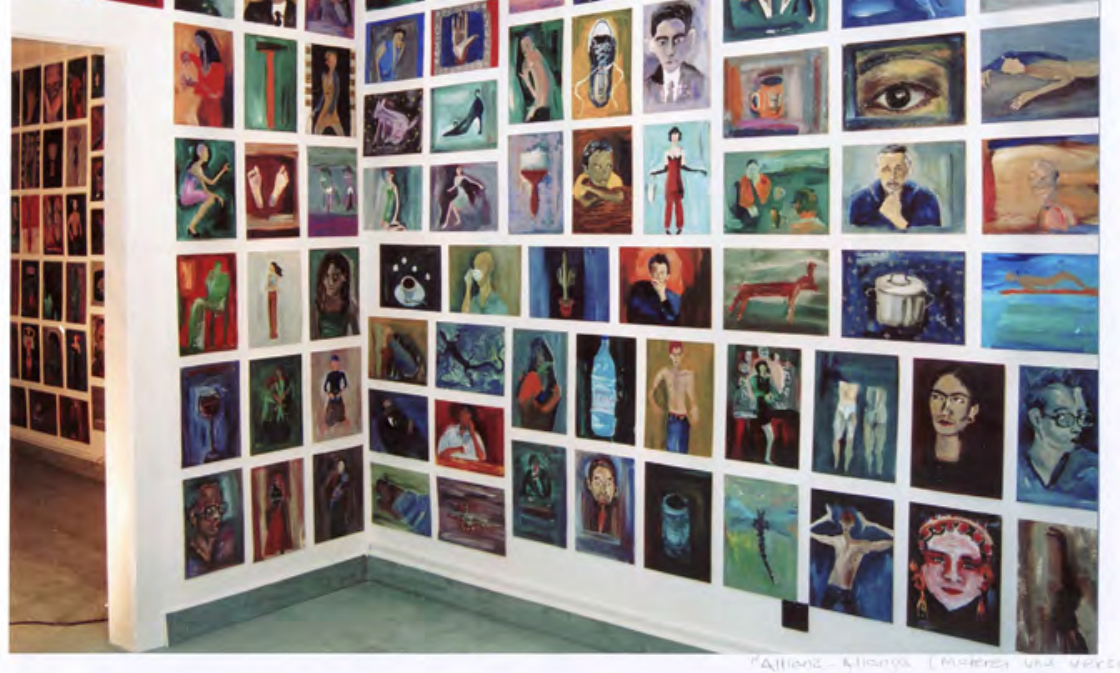



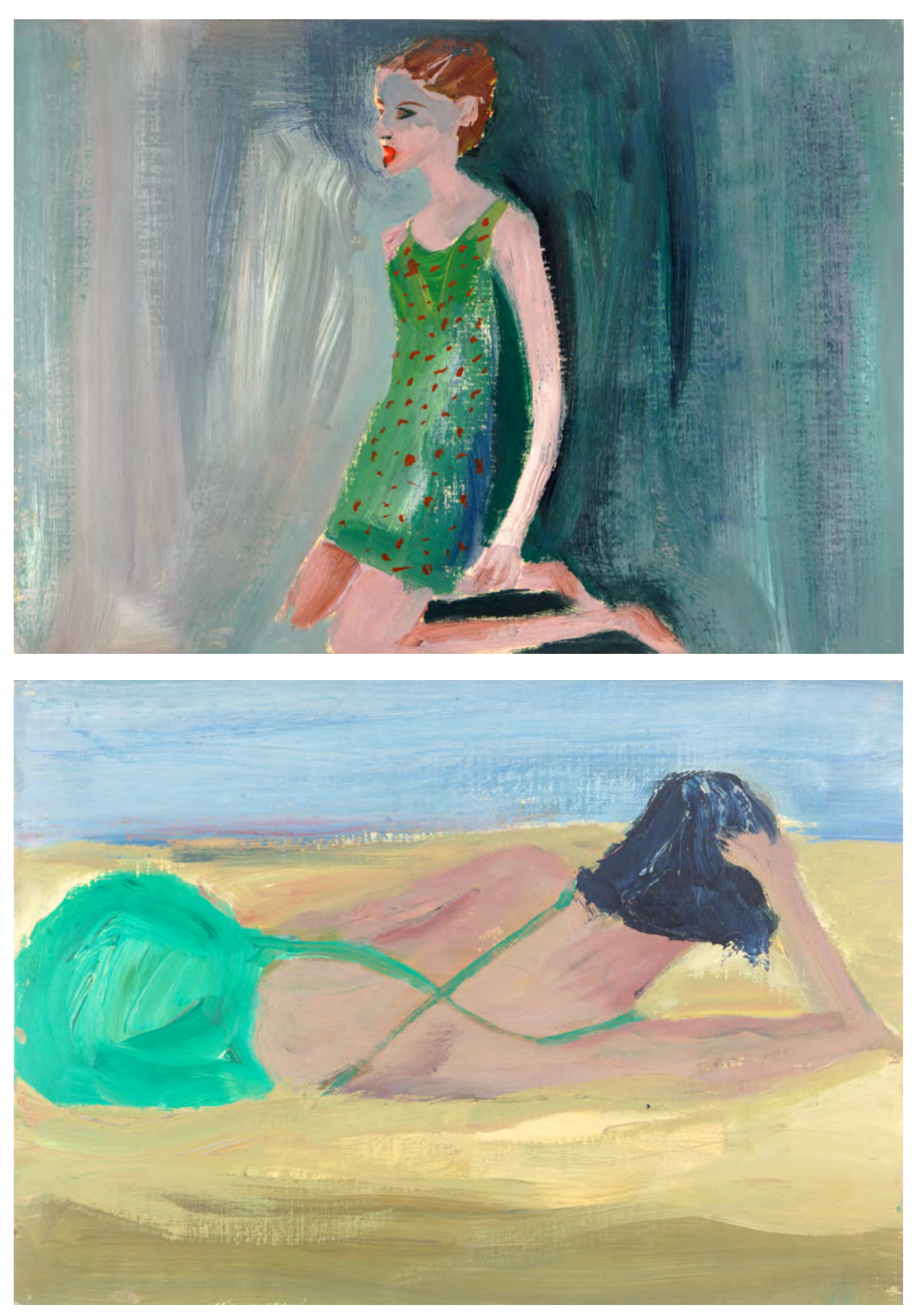

$\oplus$

Allianz-Aliança: Pintura e Seguro, Fellbach-Sttutgart, Alemanha, junho de 1997, óleo sobre papel, 33,5 x 24 cm 

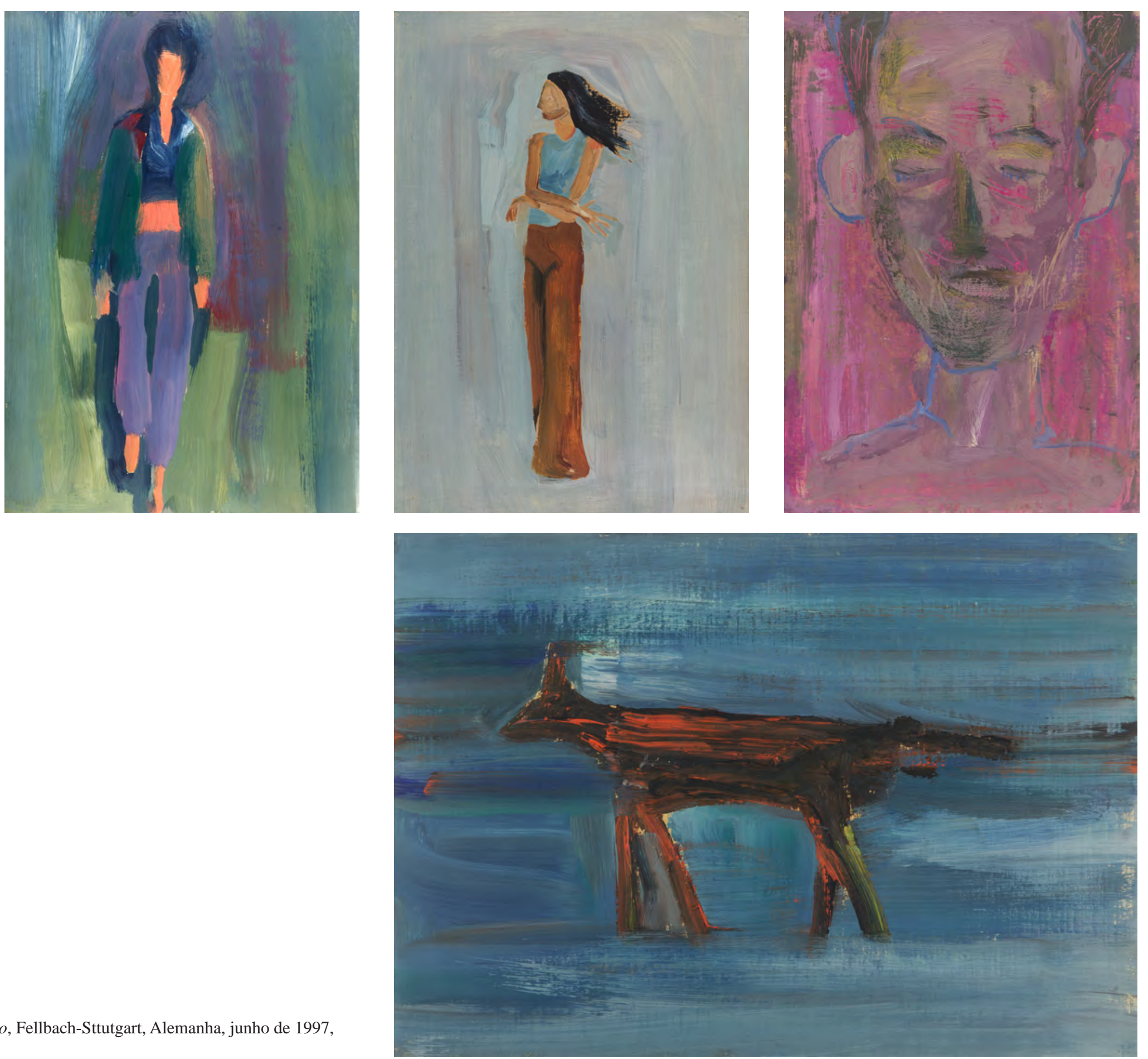

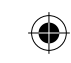

Allianz-Aliança: Pintura e Seguro, Fellbach-Sttutgart, Alemanha, junho de 1997, óleo sobre papel, 33,5 x $24 \mathrm{~cm}$ 


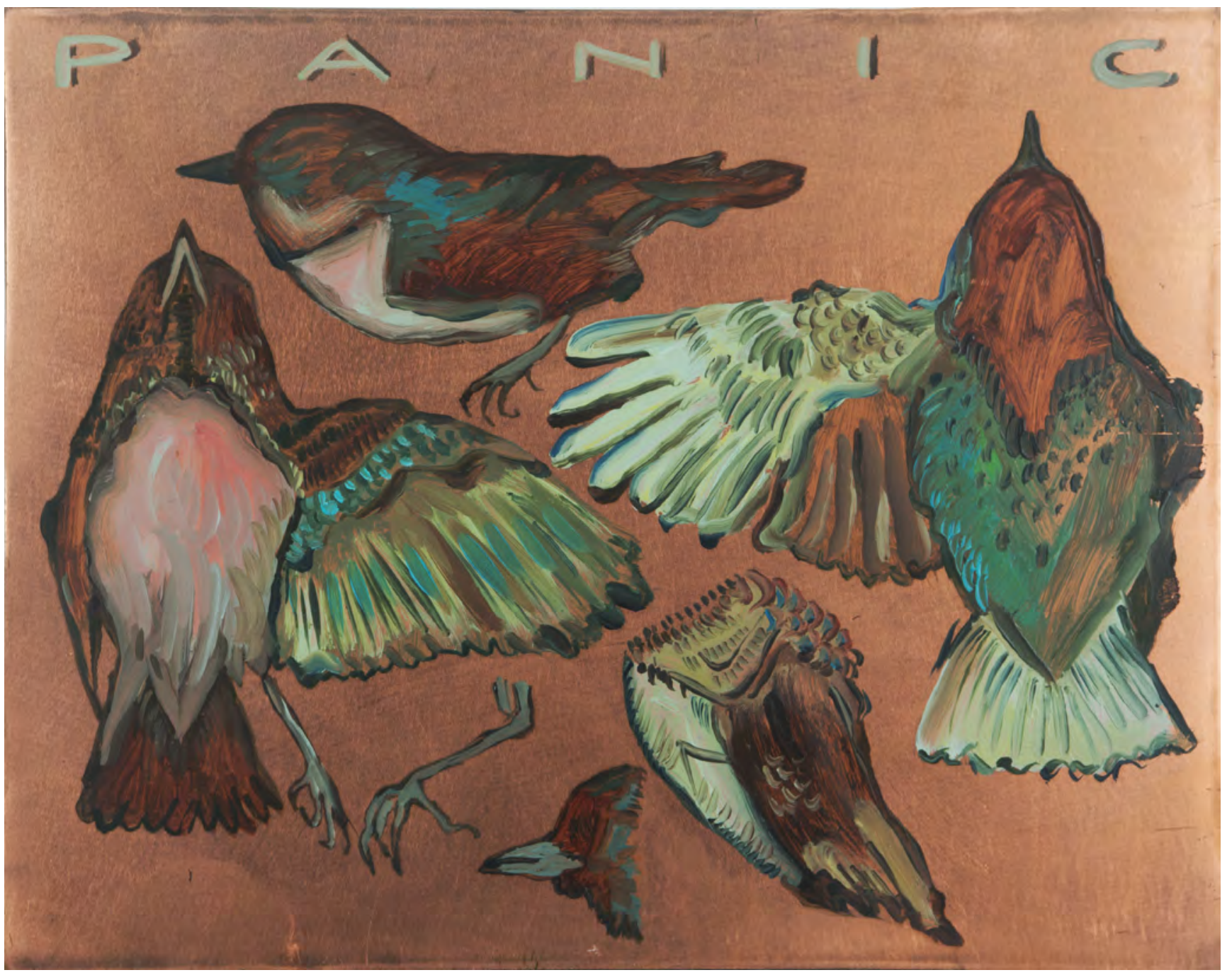

Obras integrantes da série "100 Pinturas para... (portraits)" 


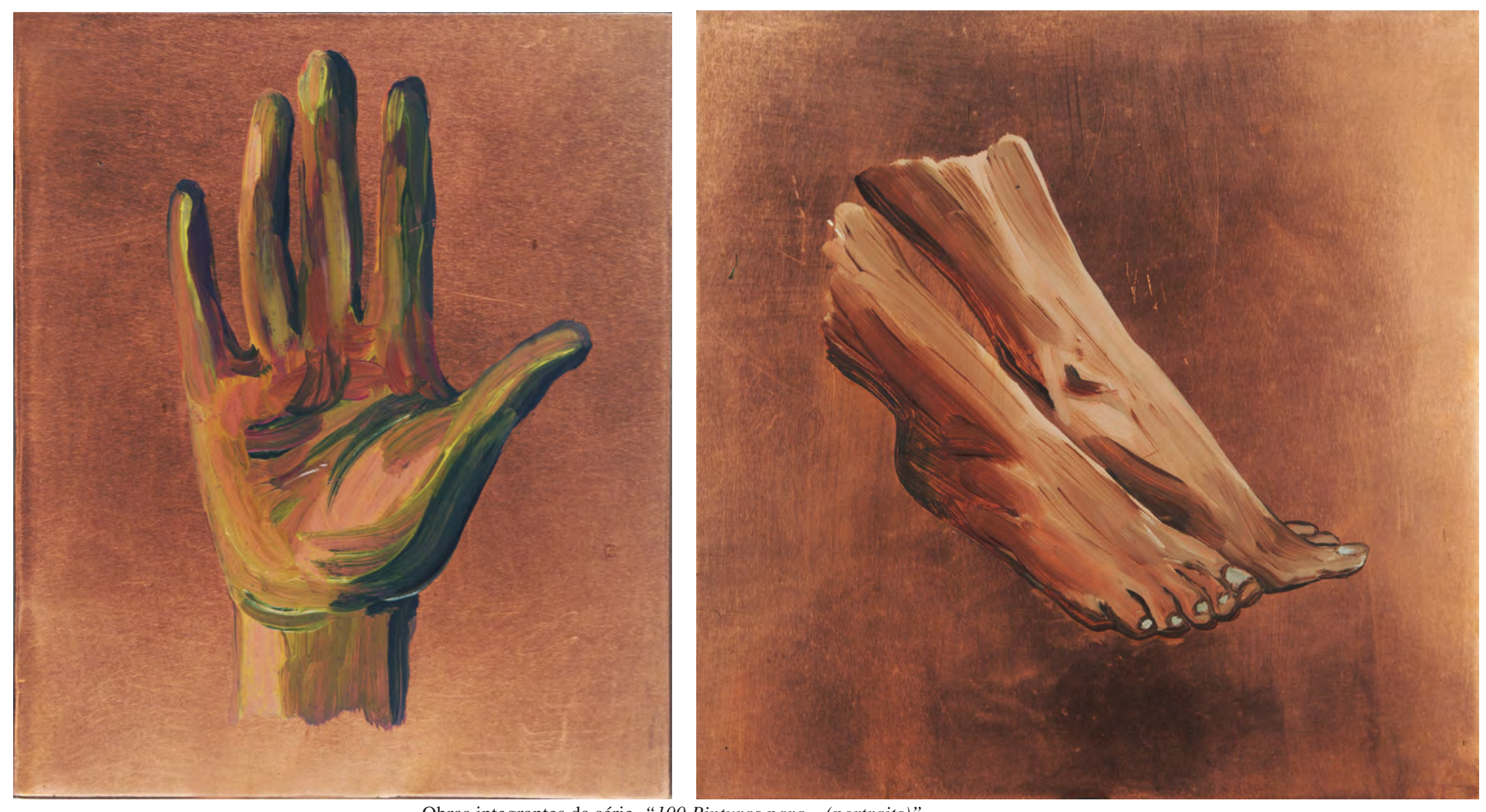

Obras integrantes da série "100 Pinturas para... (portraits)” 


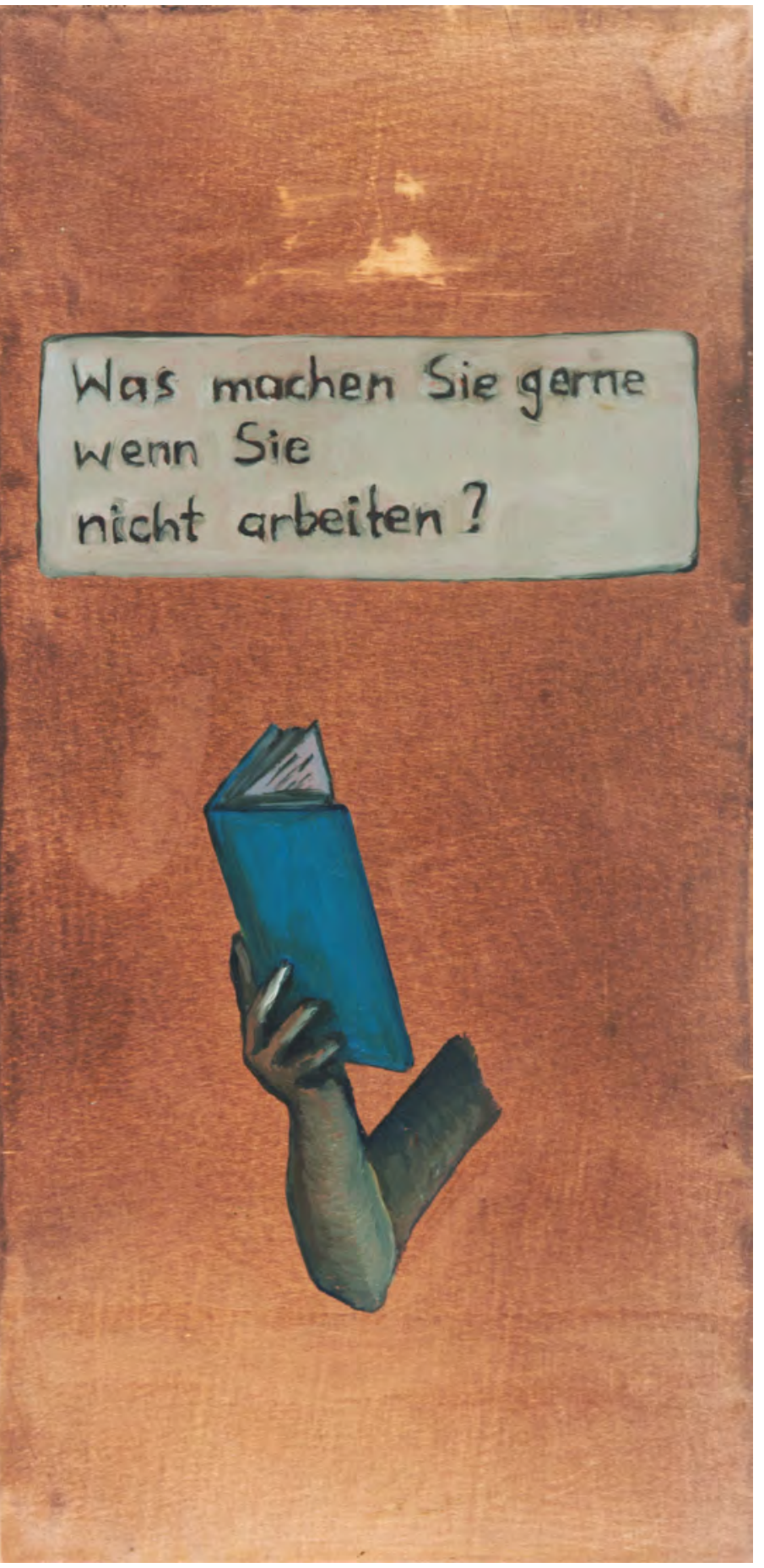

$\oplus$ 

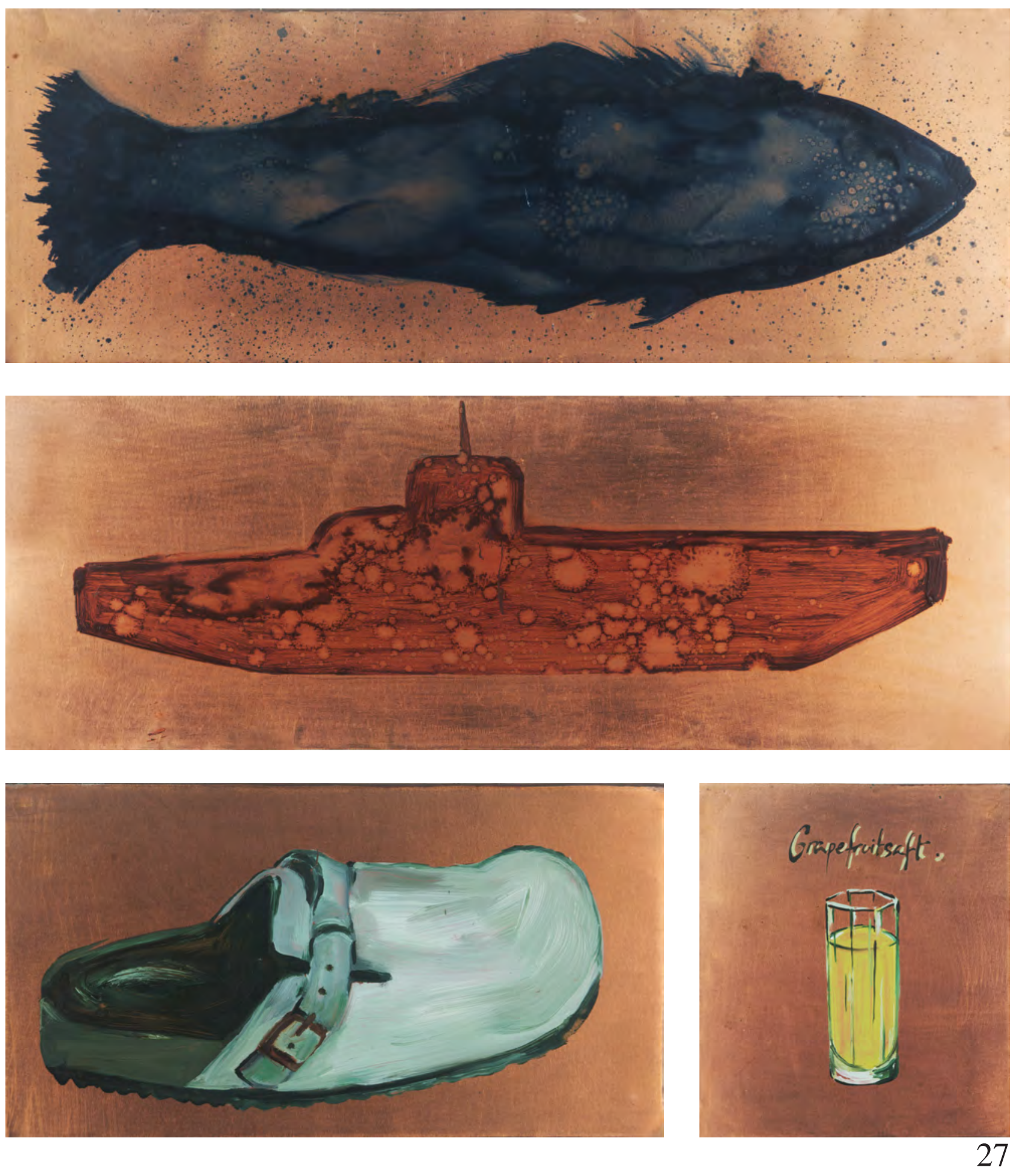

$\oplus$

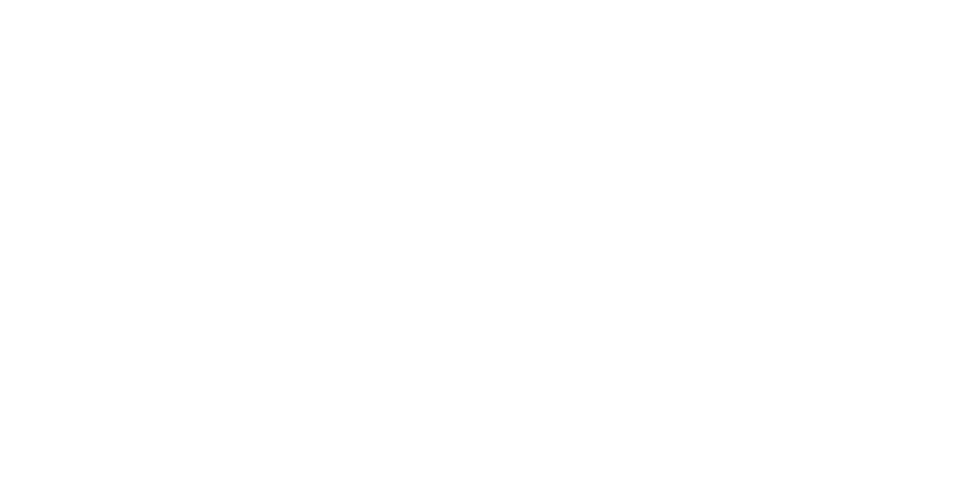




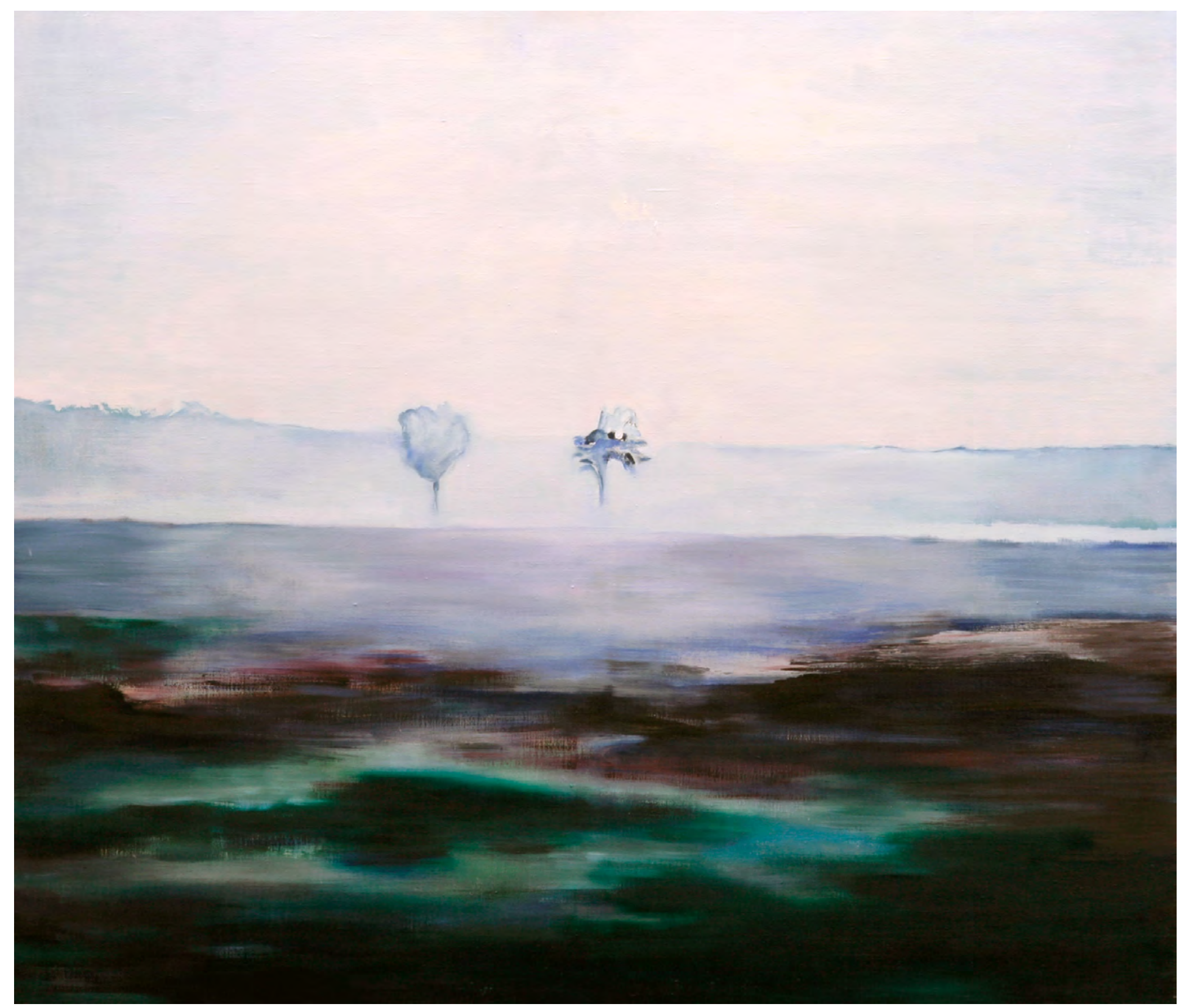

Paisagem com duas árvores, 2006, óleo sobre tela, 125 x 140 cm 


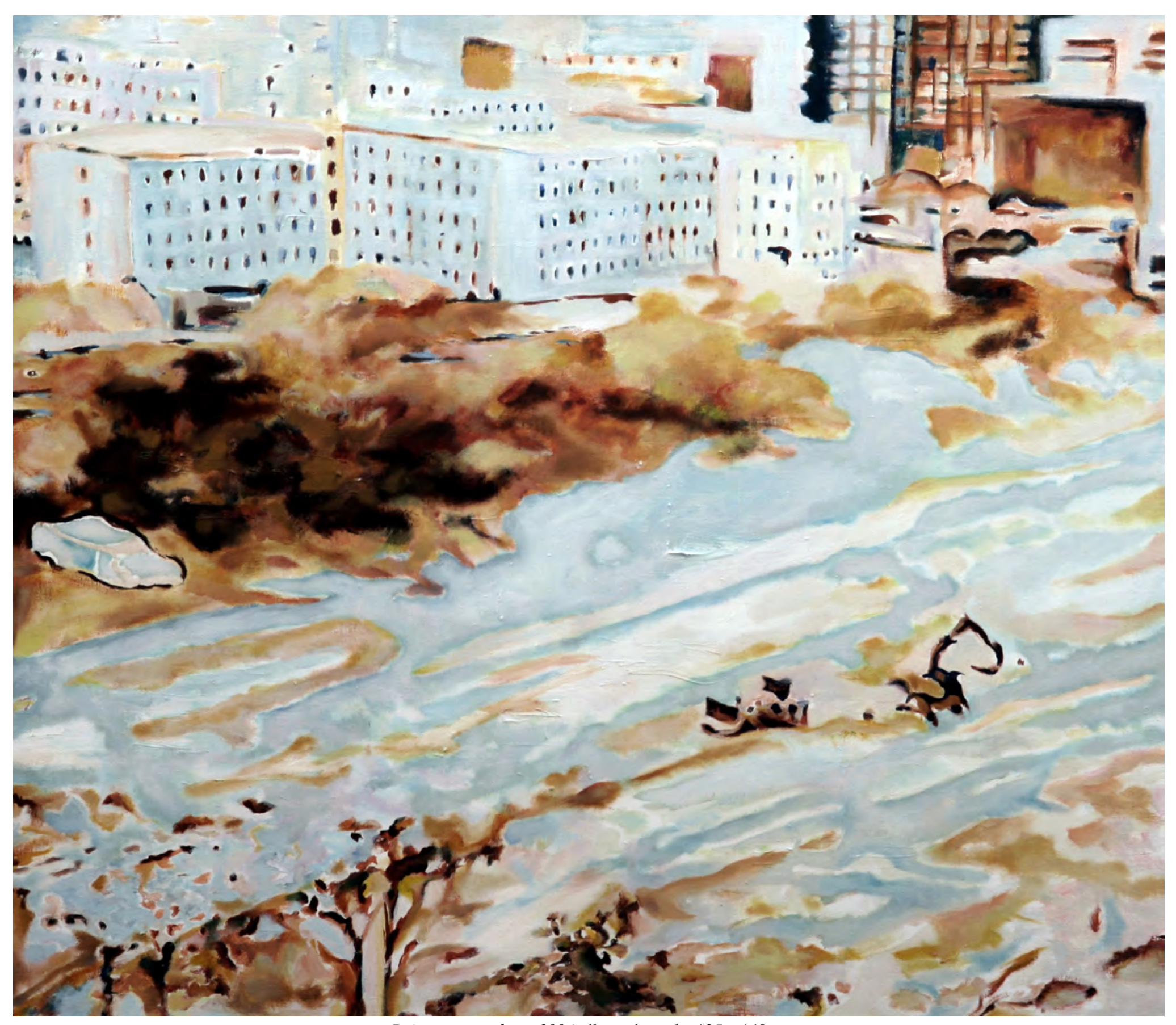

Paisagem em obras, 2006, óleo sobre tela, 125 x 140 cm

$\oplus$ 


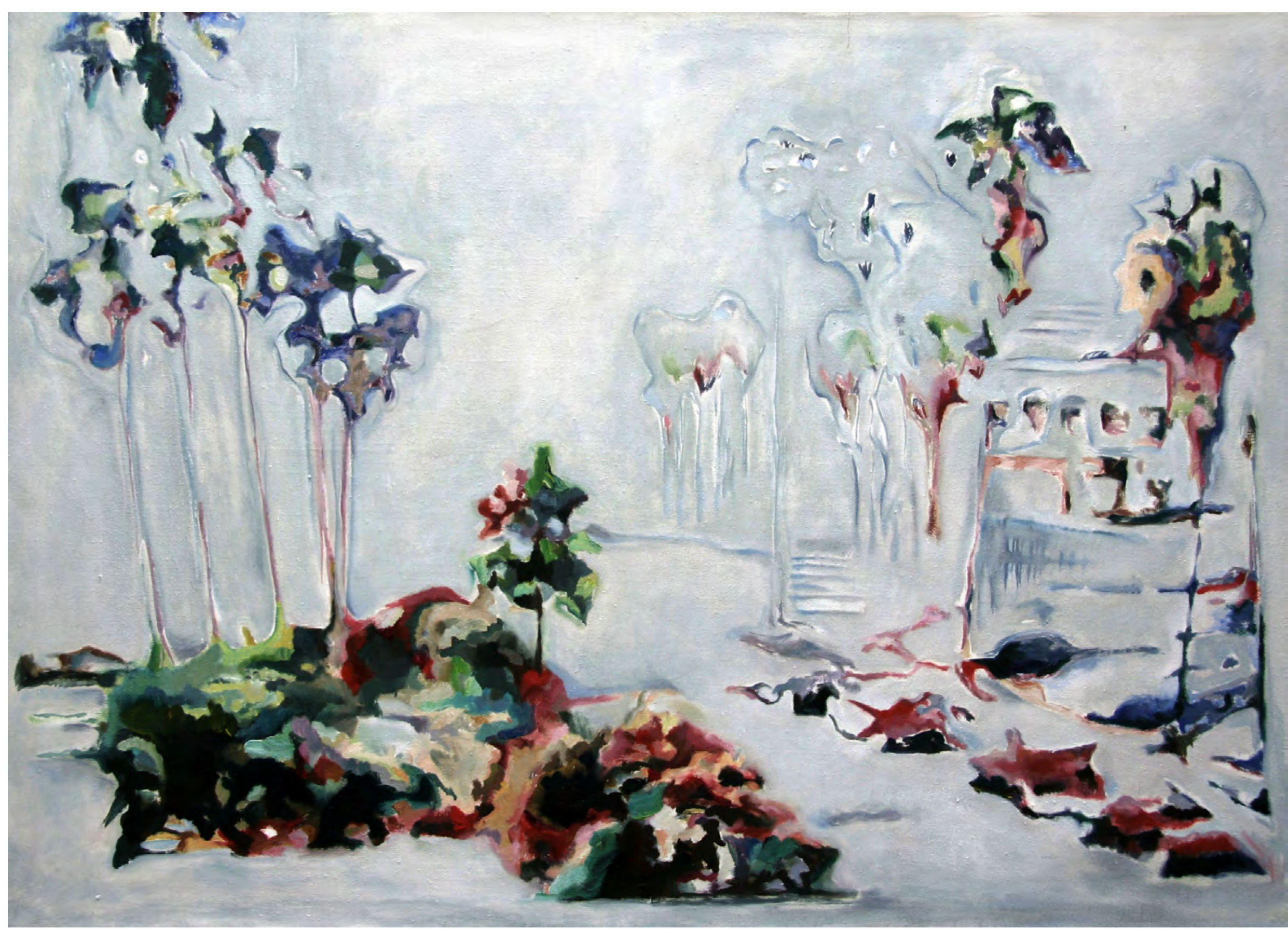

Paisagem branca, 2006, óleo sobre tela, 100 x 140cm 


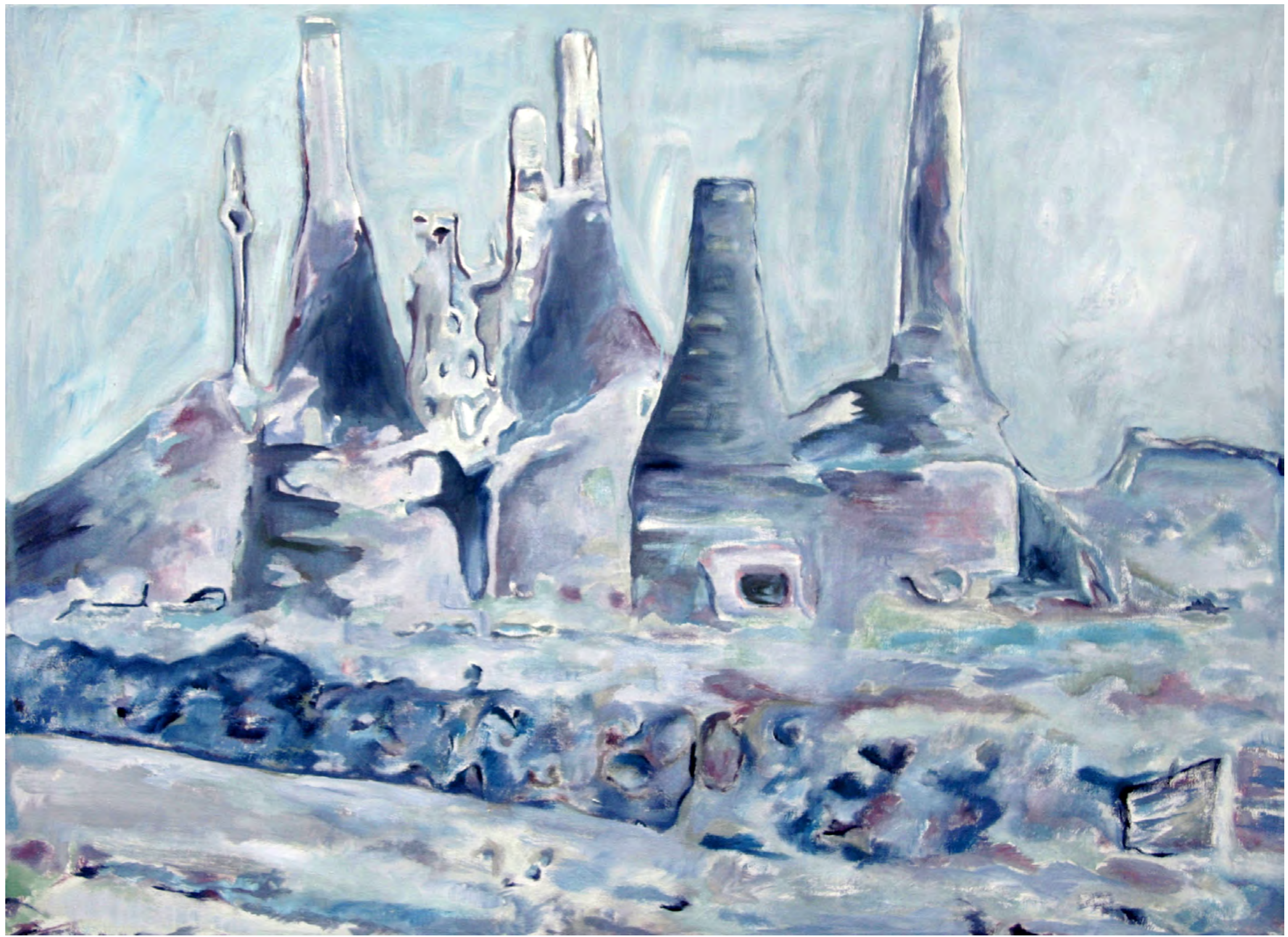

Paisagem morta, 2006, óleo sobre tela, 130 x 95cm 


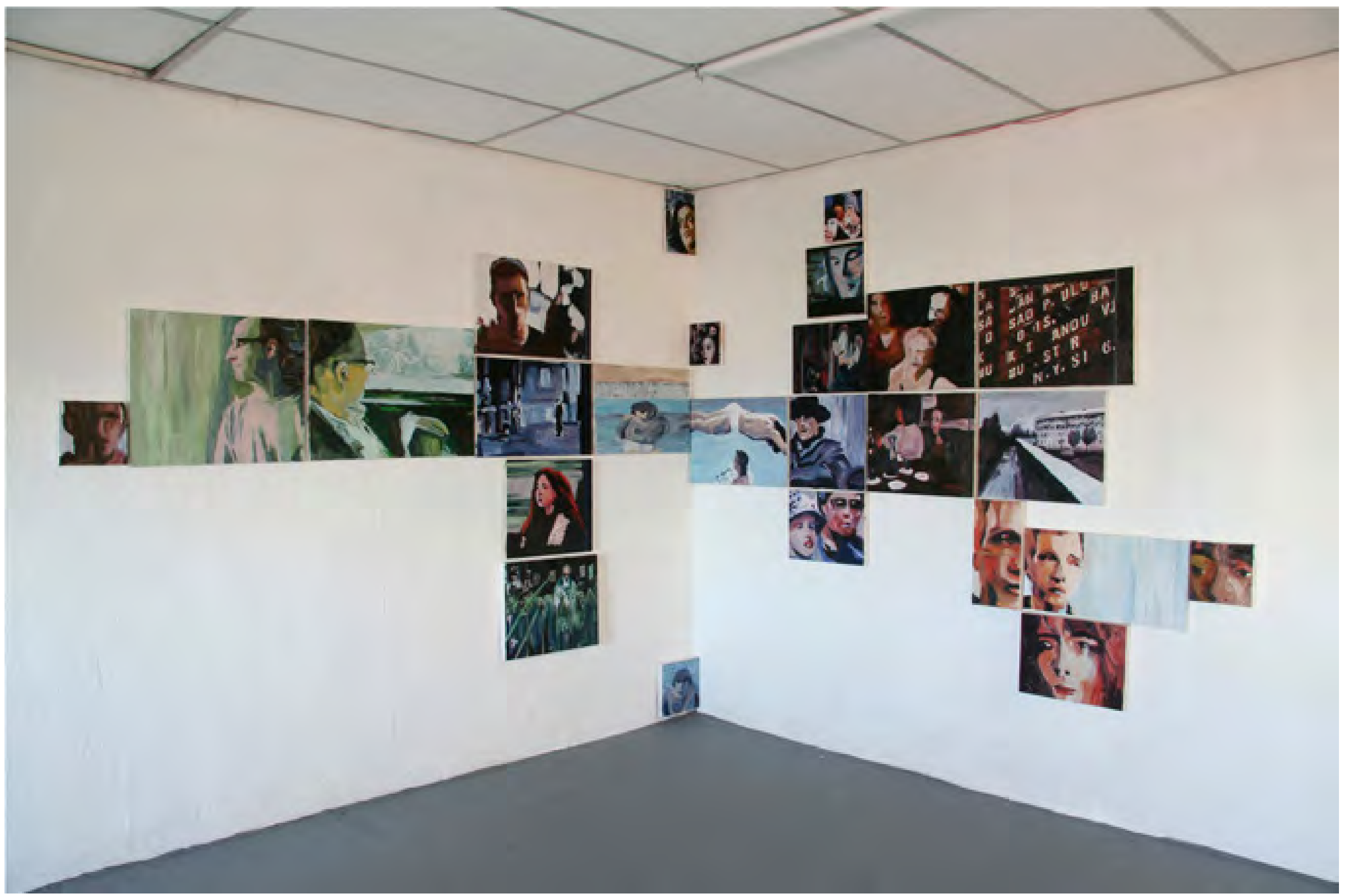

Instalação de pinturas da série Verdades Inventadas (situação de ateliê), 2009 


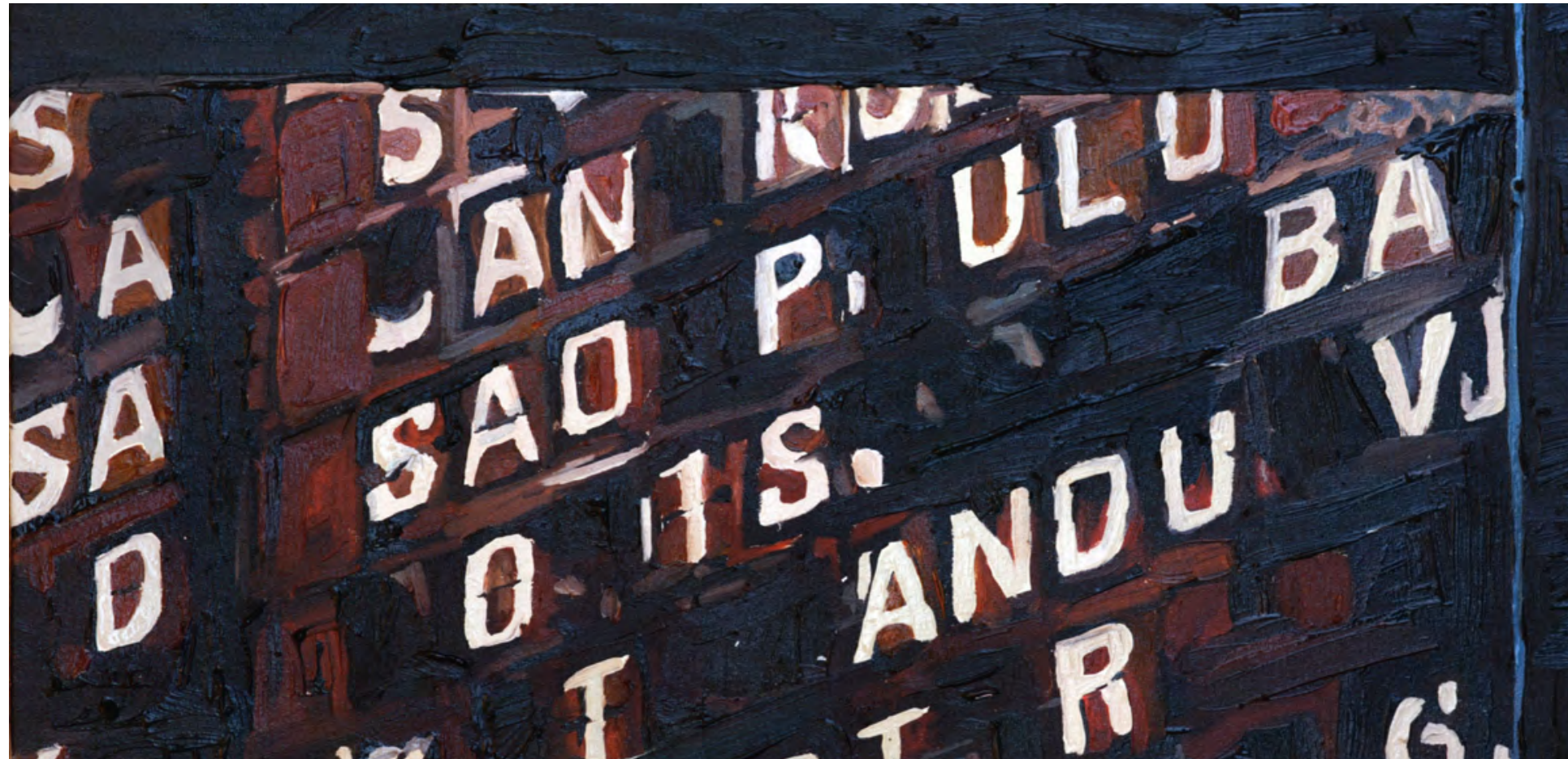

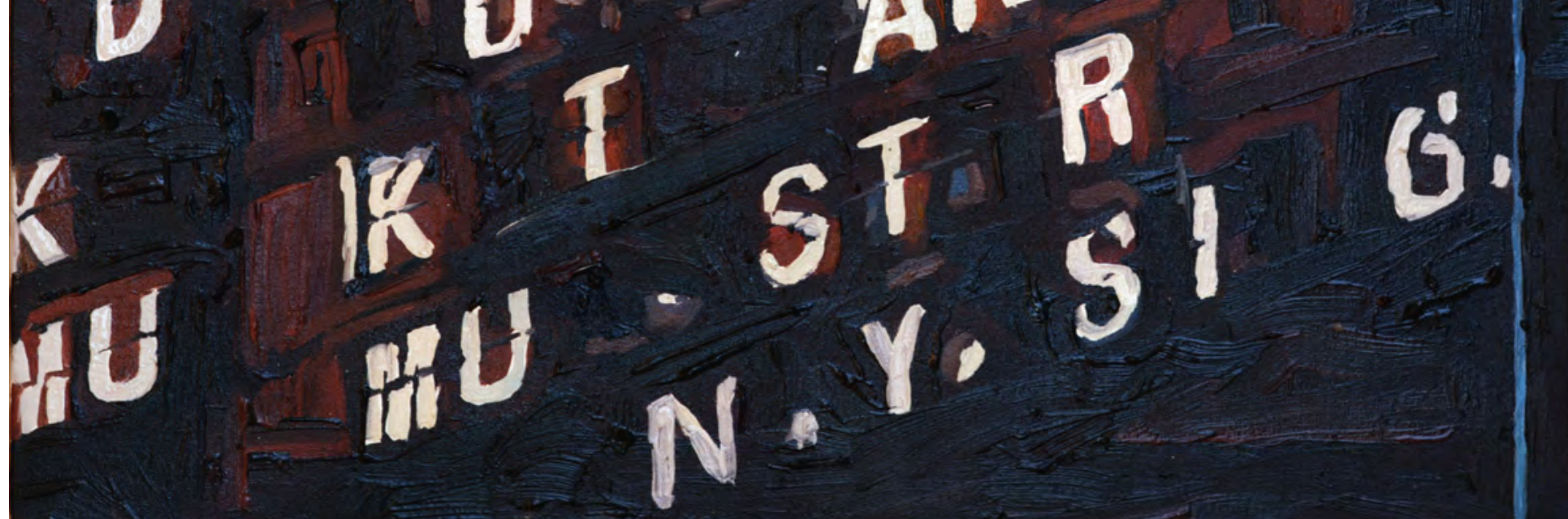




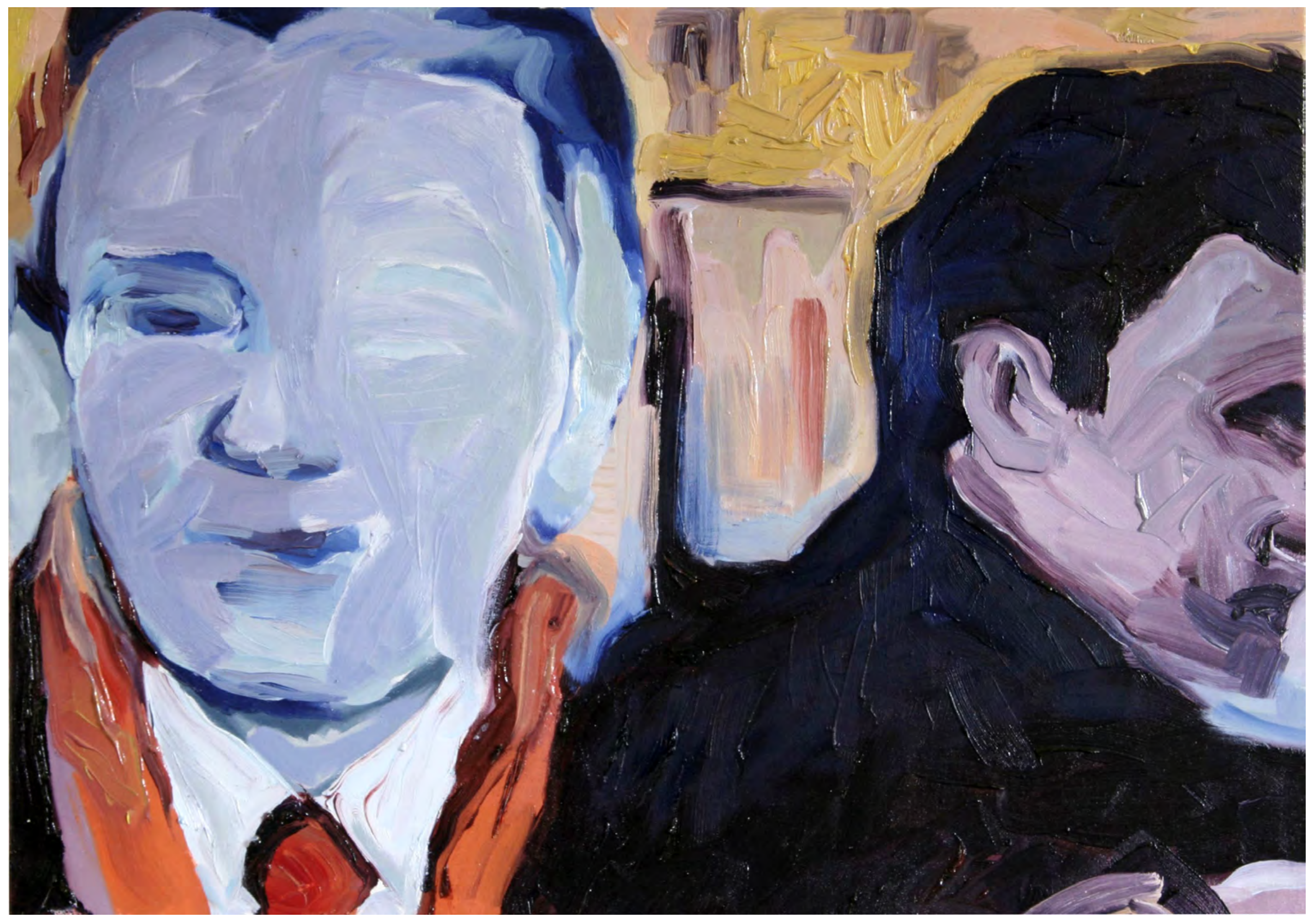




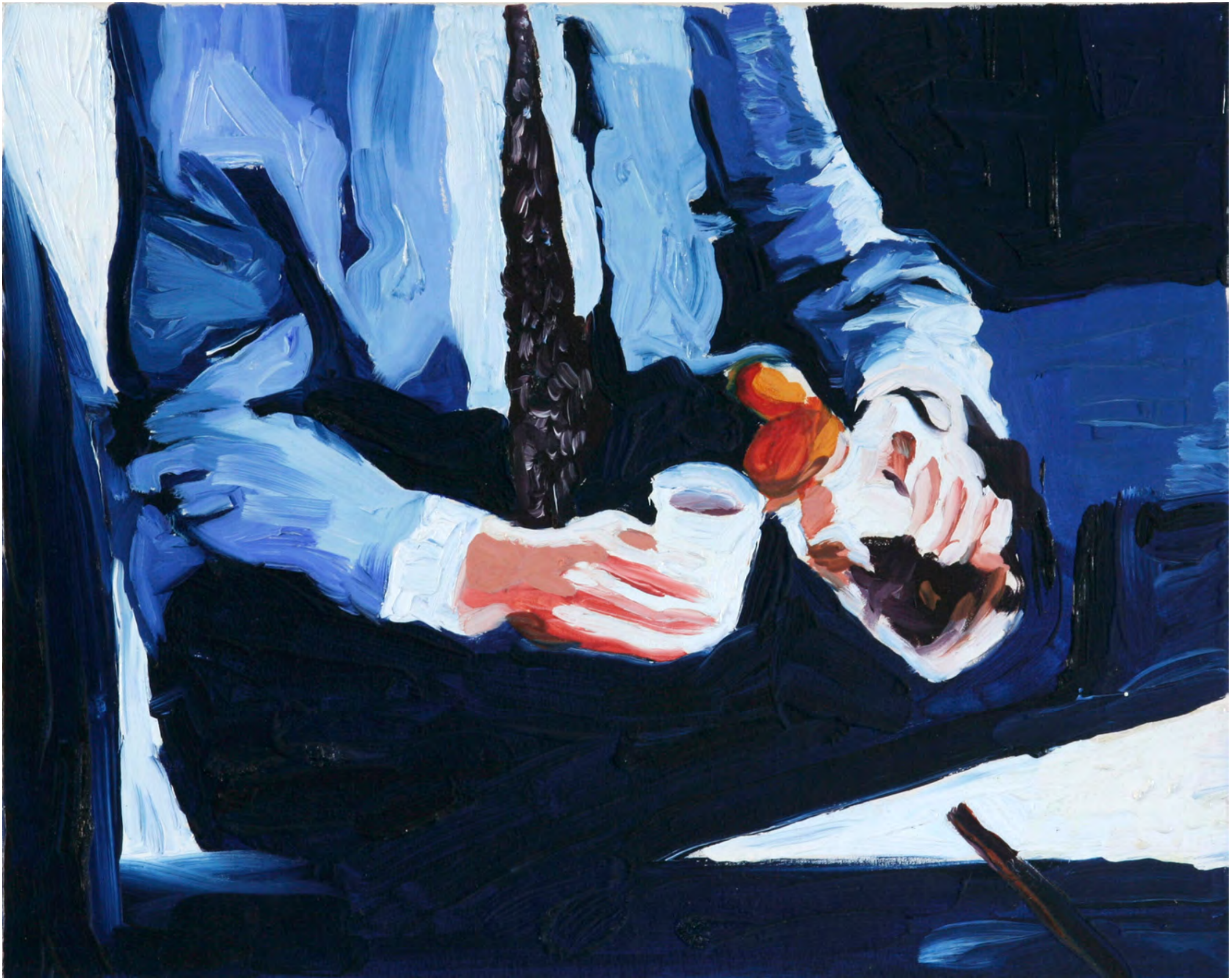

Engravatado, 2007, óleo sobre tela, 40 x 50cm 


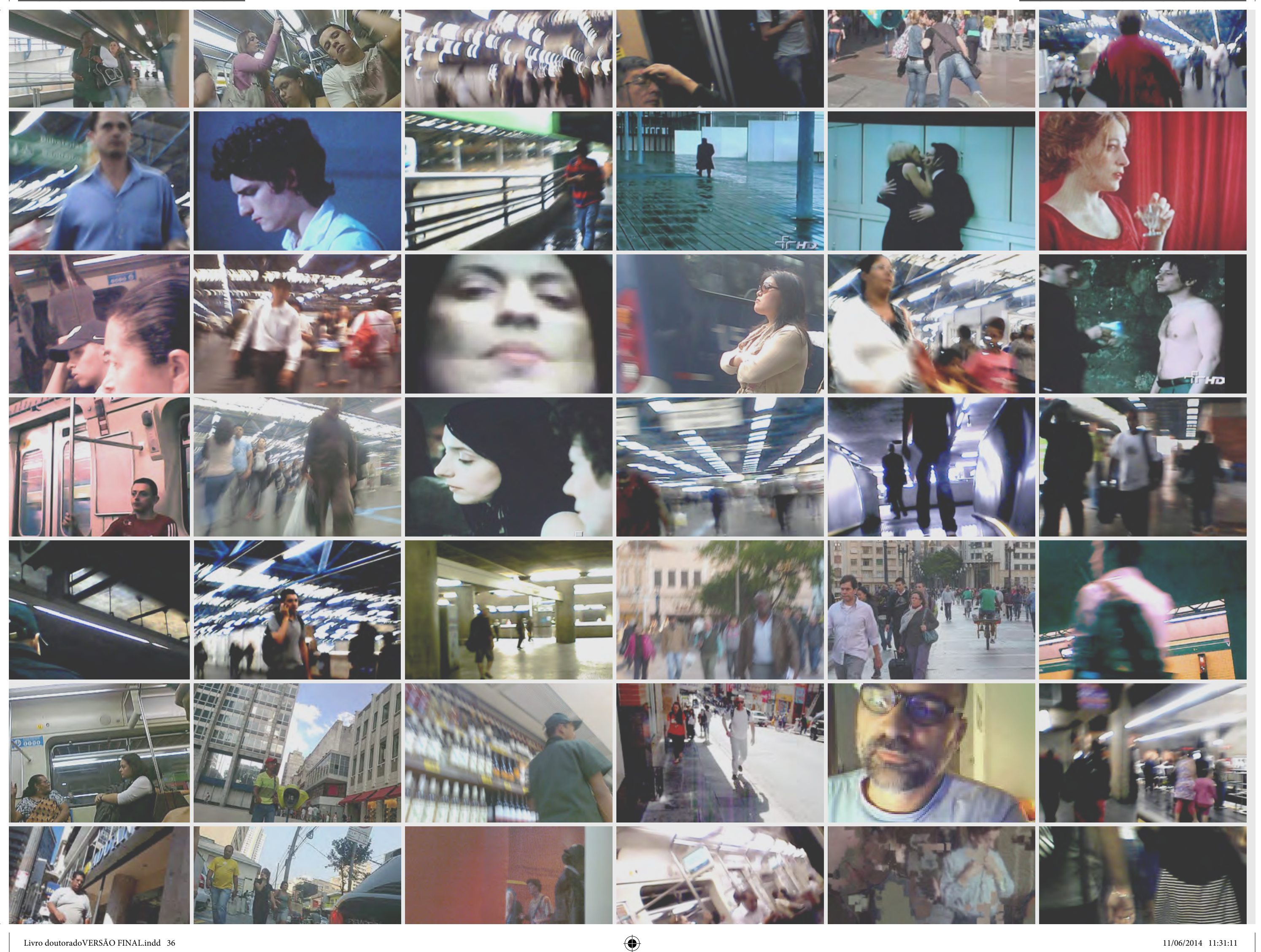




\section{PAUSA PARA PINTURA}





\section{Intenção de representar}

Ver o que se passa em minha volta é parte importante para desencadear uma série de ações que se transformam em pintura. Coisas do dia a dia que me são familiares e próximas me despertam um anseio como aquele que motivou os pintores românticos, o indefinível que existia além das coisas.

Mesmo minha pintura não sendo de observação, a imagem que utilizo é escolhida em decorrência deste treino do olhar para o mundo real, para o meu cotidiano.

A escolha das cenas de filmes da internet, as fotografias que me aproprio e os vídeos que realizo são ações intrincadas com a experiência do ver.

O crítico britânico David Sylvester, afirma que as condições do ver objetivadas nas esculturas de Giacometti “não são meramente aquelas do ver, mas as do ver com intenção de representar: as pessoas só se preocupam com a distância em relação ao que estão olhando e com a indefinição de seus contornos se estiverem tentando representá-lo, ou se tiverem o hábito de tentar reproduzir coisas." ${ }^{1}$

Fiquei pensando se não seria pelo mesmo motivo que as minhas figuras humanas se misturam com o fundo e seus contornos são tão indefinidos.

Quando saio para capturar imagens na cidade tenho a intenção de buscar estímulos para a pintura. Essa ação justifica meu trabalho: transmitir as condições do "ver" através dos filtros colocados diante da realidade tendo estado lá.

A imagem fotográfica que estimula a imaginação à representação dela mesma é aquela que me toca de maneira especial, que contém o punctum de que falava o semiólogo Roland Barthes:

"O punctum de uma fotografia é esse acaso que nela me fere (mas também me mortifica, me apunhala).” 2

Para mim, no entanto, é onde começa minha pintura. O instantâneo, o tempo congelado é eliminado. Não fosse assim, não seria pintura. 


\section{De longe e de perto}

Na escolha dos frames costumo intercalar imagem em close-up com cenas panorâmicas, o que gera uma variação de escala e formatos de telas. Faço isso para criar dinamismo quando em conjunto, ou seja, no processo de montagem.

Nos trabalhos apresentados na conclusão do mestrado havia também uma variação de técnicas e gêneros que reforçava o aspecto narrativo da pintura.

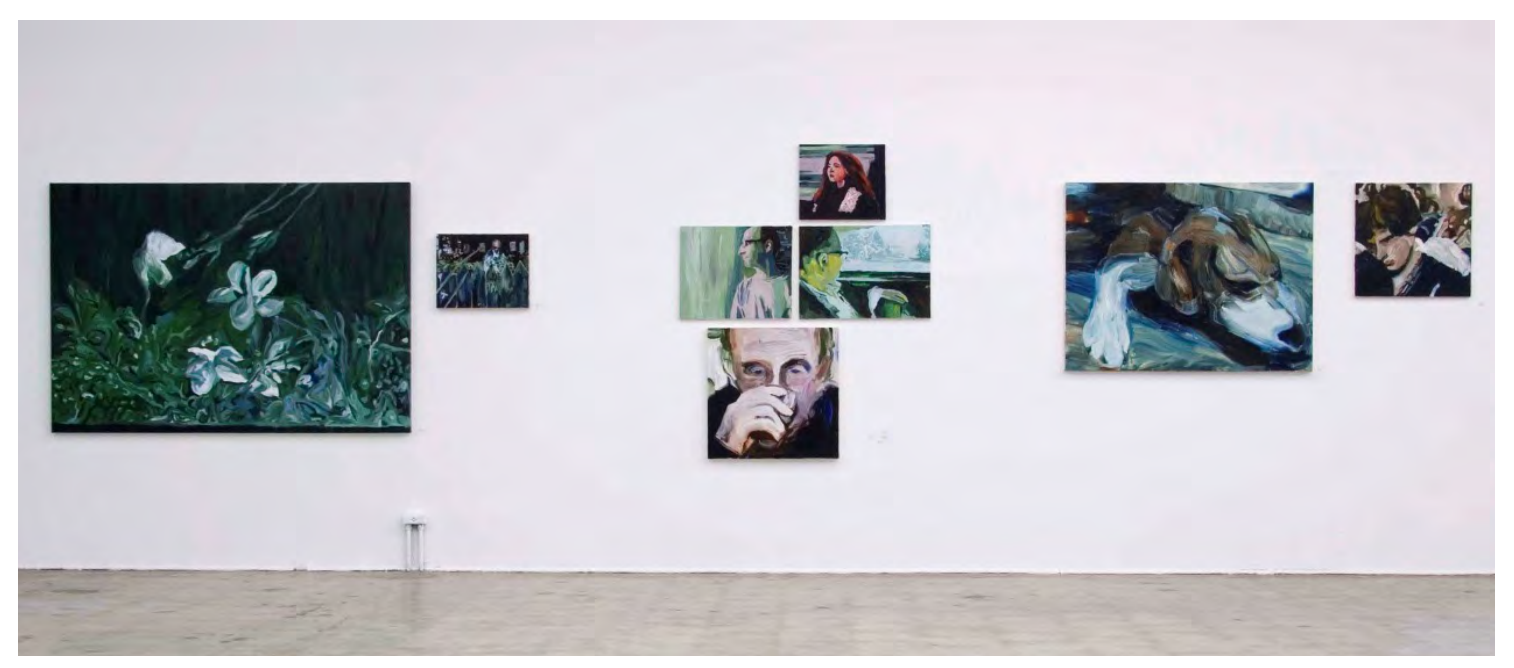

Detalhe da exposição de conclusão do mestrado, MAC-USP, 2009

Nos atuais, essa alternância em relação aos gêneros é menor, predominam retratos e cenas urbanas. Em alguns há ênfase na pincelada que deixa rastros, que mistura os planos de cor; em outros, planos mais chapados, áreas definidas, pinceladas mais "sólidas" e que não misturam as cores direto na tela.

A questão do olhar para aquilo que está distante se intercalando com o que está perto se tornou o mote da pintura e é perceptível na montagem dos quadros no espaço.

A respeito disso, gostaria de citar um artista, com quem tenho afinidade: Edvard Munch. Em um de seus poucos escritos, encontramos um desabafo sobre uma crítica negativa que recebeu devido ao modo de apresentar as pinturas da série "Friso da Vida". 


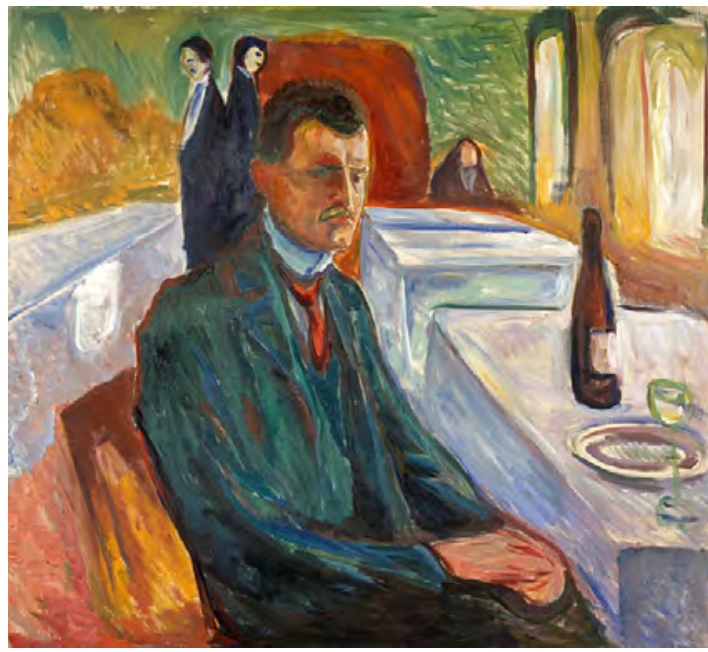

Edvard Munch, Auto retrato com uma garrafa de vinho, $1906,110 \times 120 \mathrm{~cm}$
A crítica alegava que elas não combinavam entre si, que possuíam técnicas diferentes e que não se apresentavam "acabadas". Ele rebate escrevendo:

“É incompreensível que um crítico, que ao mesmo tempo é pintor, não veja nenhuma coerência nesta série de pinturas. Nem uma mínima coerência, como ele afirma.

A metade das pinturas apresenta tal coerência, que com grande facilidade pode-se transformá-las numa grande composição. As pinturas com a praia e as árvores - onde os mesmos tons de cor são recorrentes - o tema da noite de verão cria a total harmonia. - As árvores e o mar formam as linhas verticais e horizontais que sempre se repetem, a praia e as figuras humanas dão os tons da vida vibrante-cores fortes são o eco da harmonia entre as pinturas. De fato em sua maioria são anotações- documentos-esboços-temas.

\section{Daí sua força. ”3}

Munch alegava que um friso não precisava sempre exibir uma unidade rígida, aliás, dizia que os frisos feitos desta maneira podiam se tornar monótonos, a ponto de não se reparar as pinturas contidas nele e que se tornariam apenas elementos decorativos.

É justamente essa contraposição decoração/provocação e o ritmo não monótono das pinturas no conjunto que busco no meu trabalho. Por essa razão, juntar pinturas aparentemente sem coerência faz parte do conceito.

Também vejo cada pintura como anotação, esboço, documento. E isso acontece pelo fato de estarem sempre em construção, por serem registros das minhas andanças pela cidade, das minhas observações.

Com a intenção de mostrar meu olhar divagante que ora se concentra em um detalhe, ora se surpreende com o todo, "retratos" ou fragmentos do corpo são colocados lado a lado com cenas panorâmicas de rua ou de espaços do metrô.

Na cidade, momentos de pausa e ação, dispersão e concentração, aglomeração e isolamento se interpõem. Os intervalos entre uma pintura e outra podem ser interpretados como passagens ou cortes abruptos.

No processo do trabalho em que utilizo o vídeo, o esboço começa na filmagem, na rua.

No ateliê, congelo a cena e trabalho digitalmente a imagem que será transferida

3 ADE, Peter A. (org) Munch und Deutschland. Catálogo. Sttutgart: Verlag Gerd Hatje, 1994, p.77. Tradução da autora. 
para a tela, com auxílio de um projetor. Nesta etapa pinto direto com a tinta a óleo ou desenho algumas áreas com lápis grafite, fazendo interpretações, mas, sempre preservando as características que me estimularam de início como traços dominantes.

Em um determinado ponto, sigo sem a projeção e me surpreendo com a pintura que fiz "no escuro". A imagem na tela do computador segue ao lado, como modelo, para que, de tempo em tempo, seja confrontada com o já realizado.

Poderia substituir essa imagem por um modelo natural, pintar a partir da observação ou mesmo da memória, mas me atrai essa possibilidade ampliada, desde a invenção da fotografia, de manipular as imagens - estas enquanto reproduções, que perderam a característica de objeto visual "tradicional".

Procuro passar para minha pintura esse acontecimento da imagem. Quando penso nos filmes que realizo, aleatoriamente nas ruas, concluo que o mais importante não é o tema da multidão e da figura humana em si, mas o quanto aquela imagem reprodutível que assisto e "re-assisto" me estimula e me leva à pintura.

Diferente de Delacroix ou Degas, por exemplo, que utilizavam a fotografia como um meio de melhor reconhecer o objeto, ou aqueles que usavam a câmera escura para traçar a lápis a imagem projetada sobre a tela, para assim obter um esboço exato, uso o vídeo e a projeção do frame sobre a tela como o estopim de um processo. Após ser desligado o projetor, uma nova etapa se inicia.

Retomando todas as anteriores, diria que primeiramente vem o filme e a manipulação digital como esboço, em segundo, a projeção e as primeiras pinceladas "no escuro" e por fim, a pintura que se liberta da projeção, mas que fica em diálogo com a imagemmodelo na tela do computador

Ainda sobre as relações "do longe e do perto", um exemplo que gostaria de abordar é um autorretrato de 2010 que parte de um snapshot de uma tela de computador. Interessou-me as deformações causadas pela transmissão de baixa qualidade e o enquadramento em close-up .

No momento em que projetei a imagem na tela de pintura, ela tomou uma proporção arrebatadora, gigantesca se comparada àquela que vemos na tela do computador, e 


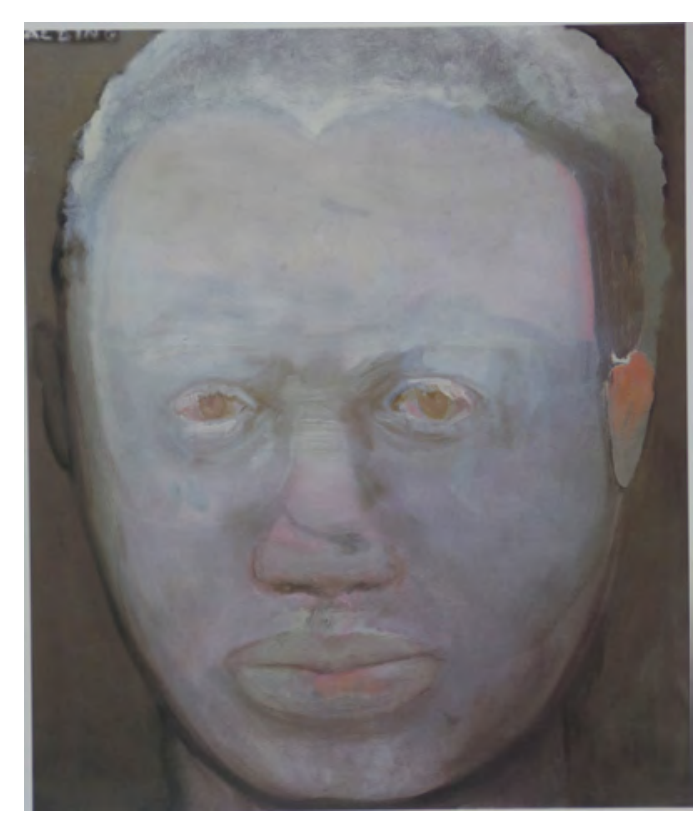

Marlene Dumas, Albino, 1986, óleo sobre tela, $130 \times 110 \mathrm{~cm}$ tornou-se pura abstração ao olhar de perto.

Em um texto, intitulado "Maior que a vida"4, a artista sul-africana que reside na Holanda, Marlene Dumas, escreve que seus rostos são muito maiores que a escala humana, ainda que ninguém se dê conta disso. Associa essa sensação com a que temos no cinema, onde encaramos a proporção aumentada das figuras humanas e das coisas como normal.

Isso não surpreende, uma vez que a capacidade de ampliar é uma das principais características da visão fotográfica e um método usado por muitos artistas.

A artista notou que esse procedimento além de aumentar o senso de abstração sobre o plano pictórico eliminava as escolhas mais básicas de composição e proporção. E foi através destes close-ups que eliminou fundos, ambientes ou lugares que achava insignificante para suas pinturas.

No meu trabalho, quando utilizo imagens em close-up, tenho essa mesma intenção de eliminar as coisas "não importantes" da cena enfatizando tanto a expressão introspectiva de uma figura como o aumento do senso de abstração que a ampliação proporcionou.Mas, minha aproximação com o cinema se dá principalmente pela sequência de planos abertos e fechados que determinam o ritmo no conjunto de pinturas.

\section{Em Estado de Trânsito}

Parte da minha produção atual vem da reflexão pictórica da experiência sobre os momentos presentes, ou seja, sobre o efêmero, aquilo que é passageiro, que está em movimento, seja dentro de um metrô em São Paulo, seja o que advém de mudanças de casa ou de cidade.

Como o procedimento do trabalho está atrelado à utilização de imagens fotográficas de pessoas na multidão em situação de deslocamento nos grandes centros urbanos, filmo com a câmera em movimento e sem interrupção para que se crie um olhar subjetivo.

Quem são esses corpos? Que cidade é essa? Corpos se deslocando rapidamente,

4 VAN DEN BOOGERD, Dominic, BLOOM, Barbara e CASADIO, Mariuccia. Marlene Dumas. London: Phaidom Press, 1999, p.116. 
desordenadamente, em forma de fila, se esbarrando, desviando, com pressa, devagar, silenciosos, gritantes, corpos- anúncio, corpos- políticos, religiosos, que entretém que vendem que cantam que roubam que dormem: indivíduos díspares que confguram uma massa amorfa.

Essa ação de "passar" por lugares com diferentes estímulos ou de seguir um fluxo ininterrupto, sendo quase levado por ele, me fez traduzir esse estado de deslocamento na multidão como um estado de trânsito.

A desfiguração e deformação que busco na minha pintura estão ligadas a essa vontade de modificação. Transformar formas existentes pelo gesto e pela pincelada buscando uma nova forma é comparável ao curso natural da vida.

De agosto de 2010 até início de 2012, residi em Porto Alegre. Esta experiência coincide com a escolha do tema da cidade e da multidão. Atribuo parte disso a esse estado de trânsito em que eu própria me encontrava: as figuras dos meus quadros se dissolvem na cidade para se tornar parte dela.

Nesse sentido, poder-se-ia definir minha pintura como uma tentativa de tornar concreto um sentimento, uma sensação e uma ação no tempo.

A experiência de morar no centro de Porto Alegre, em específico na Rua dos Andradas, foi inspiração para uma parte desta reflexão que faço agora.

\section{Figuras na plataforma}

As imagens que colho das superfícies (ruas) e subterrâneos (metrô) de São Paulo e Porto Alegre fundamentam as superfícies da minha pintura, que assim como as cidades, também possuem camadas.

Artistas modernos se inspiraram em elementos urbanos. Cito aqui três exemplos que considero relevantes para meu trabalho atual. Um deles é Mark Rothko, que na sua primeira fase, na década de 1930, realizou pinturas com imagens do metrô de Nova York, as quais guardavam certa influência com a linguagem dos artistas da assim chamada cena americana. 


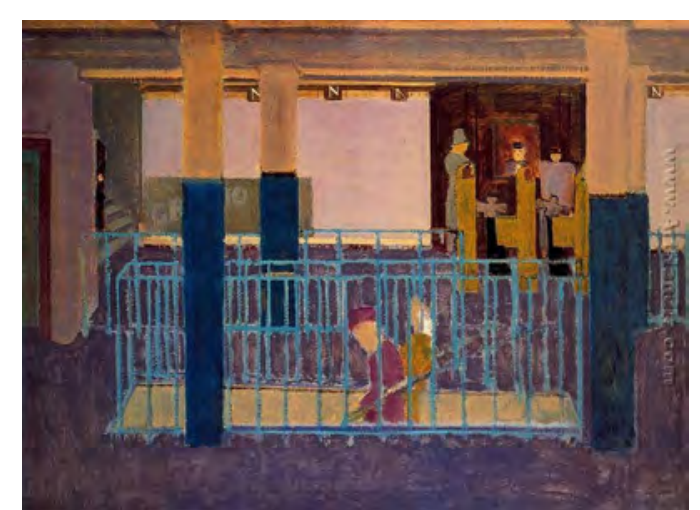

Mark Rothko - Entrance to subway, 1938, óleo sobre tela, 86,4 x 117,5 cm

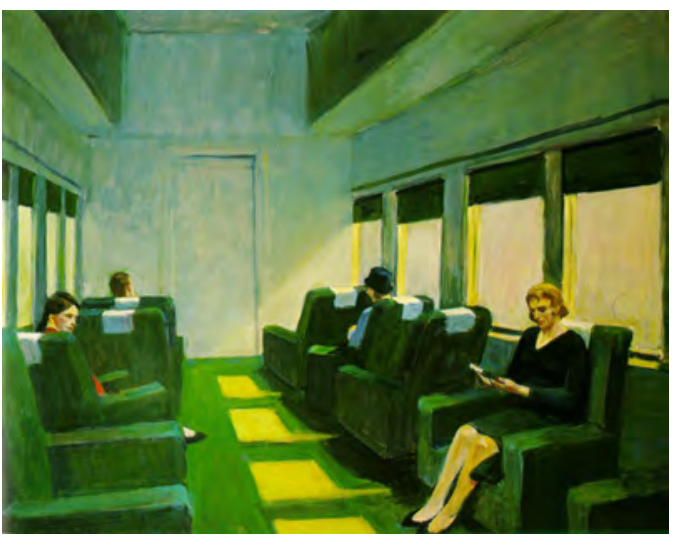

Edward Hopper, Chair Car, 1965, óleo sobre tela, 101,6 x $127 \mathrm{~cm}$

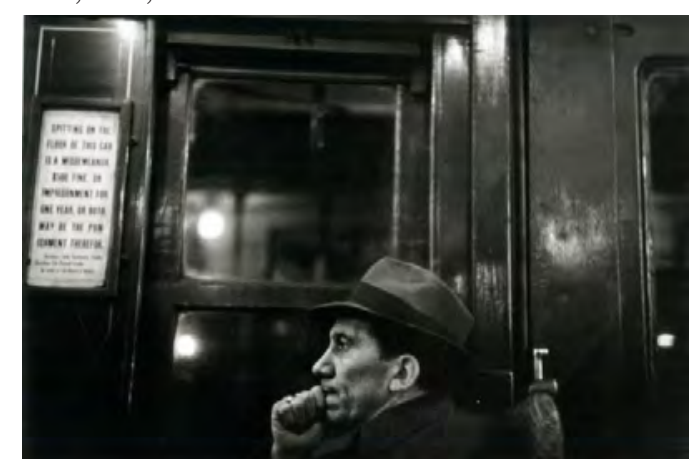

Walker Evans, da série Man are called, fotografia, 1938/41
Esta época da Depressão econômica, também produziu um artista como Edward Hopper, em cuja pintura, pode-se dizer, a vida cede lugar para o inanimado. Basta lembrar a justaposição das figuras isoladas, emolduradas pela arquitetura de Nova York, com os frios ambientes enfatizados por linhas retas .

Outro exemplo é o fotógrafo Walker Evans que fotografou o metrô, entre 1938 e 1941 realizando retratos de desconhecidos. Para este projeto vestia um casaco que escondia uma câmera de 35 mm com um disparador que lhe chegava até a mão. Havia algo no olhar dessas pessoas que parecia ter sido capturado num estado inconsciente, ao mesmo tempo passivo e inquieto.

No meu trabalho, também exploro a temática do metrô e seu aspecto "existencialista" e admito, por isso mesmo, certo parentesco com esses artistas. Mas, busco, sobretudo, contrapor esse estado de trânsito com o devaneio que este propicia, juntamente com o filme que realizo para captar esses momentos.

Nas pinturas Calça Vermelha e Plataforma pessoas são representadas na plataforma do metrô.

Elas têm o mesmo peso pictórico que o espaço que habitam. Mesmo no contraste entre as linhas diagonais (que dominam a composição) e as linhas orgânicas dos corpos, consegue-se estabelecer uma relação de fluidez de formas que enfatiza o grau de pertencimento da figura ao espaço.

Em Calça vermelha, por exemplo, as formas se dissolvem a ponto de quase não identificarmos as figuras. São massas de cor e luz num espaço que sugere movimento.

O branco da luz do teto e o amarelo da faixa de segurança formam diagonais que puxam nosso olhar para um ponto central à esquerda. Neste, localiza-se a figura de calça vermelha.

A cor é transparente e ilumina o quadro: quer dialogar com o amarelo da faixa, apesar deste estar rebaixado pelo branco. Na verdade são duas cores quentes que se destacam do ambiente dominado por cores frias.

O verde do chão, que também é vibrante, serve de ponte entre o primeiro e o
Pág.80

Pág.81 
segundo plano, além de servir de passagem do amarelo para o vermelho. Se não fosse ele, o vermelho ficaria isolado e desequilibraria a composição.

A área escura que forma um triângulo à direita "engole" a pessoa mais próxima do espectador. Ela está de costas e vira a cabeça em direção às figuras da esquerda. Pode estar observando-as, mas também pode estar simplesmente perdida em pensamentos a espera do trem que está para chegar. A figura está em pose relaxada, o que passa a ideia de espera e imobilidade.

A figura do meio é ambígua, carrega uma mochila nas costas e parece entretida com algo nas mãos. A de calça vermelha carrega uma bolsa grande, do tipo sacola e se mantém em pose atenta de espera. Seu olhar é para frente e está prestes a se mover dali.

São três atitudes bem distintas sugeridas na cena. O aspecto de introspecção surge pelo fato delas não se comunicarem. Pode se ver "fragmentos" de outras pessoas entre elas, pinceladas em várias direções e sobreposições, dificultando a identificação.

O chão tem o mesmo tratamento das figuras, o que se repete em outras pinturas. As sombras e os reflexos lembram elementos fluidos: as pernas da figura à direita parecem derreter e fundir com o chão.

O estímulo para passar essa ideia de fluidez também vem da imprecisão das imagens de onde as pinturas partem.

A tinta a óleo, por ser pastosa e "moldável”, combina com meu modo de deixar rastros visíveis de pincel e misturar novas camadas sobre as molhadas, sem pressa.

\section{Movimento na imobilidade}

No ato de caminhar pela cidade existem sempre as paradas, seja para atravessar uma rua, na espera de um transporte público ou no congestionamento de pessoas aglomeradas. Há uma imobilidade momentânea dos corpos, mas algo se passa nesta espera.

As dualidades do vivo e do inanimado invocam a noção de "movimento na imobilidade". Através da cor e da forma, juntamente com a pincelada, a matéria pictórica da 
figura se mistura com o fundo, um ritmo surge, uma sensação de movimento é reconhecida.

Giacometti ao relatar sobre uma mudança crucial na maneira como via o mundo no momento em que entrava no cinema e o momento em que saía, afirma que sua visão tornava-se fotográfica e tudo tinha um ar de absoluta imobilidade, causando-lhe uma sensação de silêncio.

“[...] a aparência de tudo parecia transformada... como se o movimento não fosse mais que uma série de pontos de imobilidade. Uma pessoa falando não era mais um movimento, eram imobilidades que se sucediam umas as outras, completamente separadas umas das outras; momentos de imobilidade que, afinal, poderiam prosseguir por toda uma eternidade, interrompidos e seguidos por outra imobilidade. ${ }^{5}$

A relação que faço do vídeo com a pintura me faz pensar sobre essas mesmas "imobilidades" de que fala Giacometti. Quando estou escolhendo o frame no computador sinto que a realidade capturada é feita de momentos de inércia. O movimento é uma série de frames, uma série de "pontos de imobilidade".

Não posso deixar de refletir sobre o tempo, afinal a cena das figuras na plataforma trata de pessoas paradas, em espera. Existe uma expectativa: o trem que vai chegar, mas ainda não está lá; as pessoas que estão lá, mas em pensamento já não estão.

O "estado de trânsito" em que as figuras se encontram é composto de momentos de suspensão.

\section{Prazer da incerteza}

Um estímulo para passar a ideia do efêmero e do transitório, seria a imprecisão das imagens iniciais. O tipo de imagem que busco em uma cena de vídeo é aquela em que se constata a indefinição, onde há borrões, tremidos de câmera, ruídos, etc.

Em um capítulo de Seis Propostas para o Próximo Milênio, Ítalo Calvino ao fazer apologia da exatidão ${ }^{6}$, como valor ou qualidade da literatura, cita o poeta Giacomo Leo- 
pardi (1798-1837), que a princípio seria um contraditor ideal de sua tese, mas que acaba se revelando uma testemunha decisiva a seu favor.

Leopardi em uma digressão em Zibaldone - um ensaio estético-filosófico - afirma que a linguagem seria tanto mais poética quanto mais vaga e imprecisa fosse. Para podermos apreciar a beleza do vago e do indeterminado é necessária a mesma atenção precisa e detalhada que ele usa nas composições de suas imagens.

A certa altura do texto percebe-se que "a procura do indeterminado se transforma em observação da multiplicidade, do fervilhar, da pulverulência..." ${ }^{\text {"7 }}$ Descreve a luz vista na cidade cheia de atrativos, que se apresenta retalhada pelas sombras e em contraste com a escuridão - diluindo-se pouco a pouco, sob os telhados.

A variedade, a incerteza, o "não poder ver tudo" e ao mesmo tempo, poder imaginar aquilo que não se vê, contribuem para esse prazer.

Em relação à natureza e à vida no campo, alega que efeitos similares produzem as árvores, as colinas, as desigualdades do solo etc. e o vasto plano uniforme de um campo aberto, onde, ainda que de maneira inversa, a luz se difunde sem variedades e a vista se perde.

Essa mesma visão proporciona a ideia de extensão indefinida, como um céu sem nuvens. A propósito disso, Leopardi observa que "o prazer da variedade e da incerteza prevalece sobre o da aparente infinitude e o da imensa uniformidade." Deste modo, defende que um céu com uma variedade de pequenas nuvens pode ser mais agradável do que um céu completamente limpo.

Isso justificaria a minha atração e encantamento, por exemplo, pela profusão inumerável de pessoas agitadas na cidade, em movimentos variados, incertos, desordenados, vagos, confusos, etc.

Em um poema de 1819, L'infinito, Leopardi faz uma reflexão sobre dois termos que constantemente aparecem em oposição nesse texto: indefinido e infinito. Para o poeta, o desconhecido é sempre mais atraente que o conhecido e a imaginação.

"O homem então projeta seu desejo no infinito, e encontra prazer apenas quando 
pode imaginá-lo sem fim. Mas como o espirito humano é incapaz de conceber o infinito, e até mesmo se retrai espantado diante da simples ideia, não lhe resta senão contentar-se com o indefinido, com as sensações que, mesclando-se umas às outras, criam uma impressão de ilimitado, ilusória mas sem dúvida agradável.”9

Penso que em minhas pinturas, a imprecisão das imagens iniciais, tem relação com esse "prazer da incerteza".

Há ambiguidade nas figuras que se misturam com o fundo, na geometria dos prédios que dialoga com as formas orgânicas dos corpos e também na repetição de elementos, acúmulo de informações visuais e tudo aquilo que agita em movimentos diversos.

Mas, para que eu consiga captar ou representar o incerto e o impreciso preciso também da exatidão, isto é, a concentração na observação do objeto, a escolha precisa da cor, o rigor da composição e a "adequação" ao tema. Além disso, as imagens capturadas em vídeo são minunciosamente observadas e trabalhadas antes de se tornarem pinturas.

Quando no processo da pintura propriamente dita, almejo a "pincelada precisa", o pincel tem que ter um tamanho específico para cada área do quadro e a superfície preparada da maneira "correta".

Isso não as faz menos expressivas, ao contrário, a incorporação da técnica, a escolha do assunto, a atenção aos detalhes só pode estar a serviço da expressividade. Dessa maneira tornam-se arte.

\section{Mutabilidade e deformação}

O movimento na minha pintura é transmitido através das passagens de cores e na construção dos planos pictóricos. Tenho usado a variação tonal, por exemplo, para dar dinamismo na composição.

Quando penso em mutabilidade faço imediatamente uma relação com a forma. Mas, forma e cor precisam estar em consonância para fazer acontecer a síntese perspectiva que define um estilo, como constata o historiador italiano Roberto Longhi.

9 Ibidem, p.78 
Ele chamou de síntese perspectiva entre forma e cor o momento histórico em que "o artista tenta superar o estágio rudimentar do puro colorismo bizantino e exprimir sinteticamente (isto é, de modo a produzir no espectador uma fruição unitária) forma e cor." ${ }^{10}$

O modo que isso aconteceu foi estabelecendo uma relação entre forma e cor em planos, que se caracterizava pela ausência de contornos de valor linear e presença do "contorno sintético". Trata-se assim, "apenas de dispor nos planos, onde o claro-escuro fica reduzido ao mínimo pela claridade solar e aberta, a substância da cor." 11

Na minha pintura isso é visível, mas, acrescentaria que é também através da deformação que se encontra a mutabilidade.

Ao escolher a cena de vídeo e manipulá-la no computador, vejo-me na ação de deformar. Desde o inicio, algumas imagens imprecisas ou indefinidas são congeladas e selecionadas por carregarem em si, algo de deformação, logo, ocorre uma mudança, uma instabilidade.

Será que deformo ou desfiguro quando simplifico as formas que vejo na projeção? E quando utilizo programas de computador para modificar a imagem?

Quando filmo as cenas de rua, estou no fluxo da multidão e entro neste estado "quase de transe". No ateliê vem à tona a consciência: a intenção de fazer uma pintura a partir da experiência registrada. Ao começar a pintura propriamente dita, volta esse estado de "quase inconsciência" mas, existe aí um intervalo entre o fazer e o olhar para o trabalho, que é quase imperceptível, que reivindica esse "estar lá" por completo. Essa concentração é imprescindível, é de onde vem a força: o momento de tornar visível o invisível.

Deleuze fala que os problemas de Francis Bacon são problemas de deformação e não de transformação o que quer dizer que a deformação é sempre do corpo. ${ }^{12} \mathrm{E}$ ela é estática, não dá origem a uma forma abstrata e ainda cria uma zona indefinida, indiscernível. 
"[...] é sobre a forma em repouso que se obtém a deformação". ${ }^{13}$

A deformação é criada a partir do estático e gera um movimento (ou a força). Não é uma simples transformação da forma. Tudo está em relação com as forças, tudo é força.

Isso surge, por exemplo, na deformação das minhas figuras na plataforma. Elas estão lá imóveis, em poses naturais de espera, mas com uma carga de força sobre elas, pois estão prestes a se locomover. Com essa carga, elas, ao serem por mim pintadas, se deformam e se fundem no ambiente.

A matéria parece a mesma: a deformação sugere fluidez e desmaterialização dos corpos; figuras se derretem ou se desmancham. É assim que na minha pintura faço surgir esse embate figuração-abstração. Uma ambiguidade se forma quando ao olhar de perto nos atemos na matéria densa da tinta e nos rastros do pincel.

\section{Entre a abstração e a imagem realista}

Estar na borda que separa a representação objetiva da realidade da abstração é mais estimulante que fazer uma pintura exclusivamente abstrata ou figurativa. Por isso escolho o trânsito entre os dois lados e faço uma pintura que celebra a oscilação e a ambiguidade. O que interessa é a qualidade de amorfia que uma imagem pode ter e, diferente da deformação moderna que se caracterizava como estilo ou marca do artista, a desfiguração na pintura contemporânea busca representar um estado de metamorfose.

Mas não se pode dizer que esse tipo de busca já não esteja presente nos modernos. Pode-se comprovar isso em um texto de Mario Pedrosa sobre Ismael Nery:

"Em tudo procurava ele a forma ou a definição, e, necessariamente, a antiforma e a antidefinição, que ia discernir na matéria ainda não a chegada à forma, ou na forma em marcha para o dilaceramento ou a dissolução. Ele abordava as coisas primeiramente por sua definição formal linear, mas logo a seguir uma curiosidade inexorável pelas entranhas das coisas o obrigava a prosseguir e a rasgar os invólucros externos, em busca de novas especulações." ${ }^{\text {14 }}$ 
Um outro dado muito presente nesse tipo de pintura é a afirmação de sua picturalidade. O conceito de pictórico, que vem de malerisch de Wölfflin, designa as qualidades formais da arte barroca e significa, entre outras coisas, a definição de ambiguidade, de fragmentação, imprecisão de cor e de contorno, ou seja, o oposto de linear. ${ }^{15}$

Mas segundo Greenberg, a linha que divide os dois conceitos, linear e pictórico, não é rigorosa nem inflexível: tanto na arte moderna quanto na arte anterior, constata-se esses elementos e muitos artistas combinaram ambos.

O expressionismo abstrato, por exemplo, é ao mesmo tempo abstrato e pictórico, o que vinte anos antes era uma combinação bastante inesperada, lembrando-se que a abstração das décadas de 1920 e 1930 se identificava com as silhuetas planas e contornos precisos do cubismo sintético. ${ }^{16}$

A pintura contemporânea livrou -se da incumbência de ser pintura. A arte em geral não tem mais o compromisso de questionar se alguma coisa é arte.

A crítica e filósofa Anne Cauquelin ao se referir ao abandono de posições fixas na arte concebe que, quando alguém, ao se referir a uma obra diz: "isso não é arte", pode-se considerar um elogio, pois:

"não é a arte no sentido que é dado a essa atividade, mas em outro, que não vemos porque ela é sem obra nem autor, ou pelo menos é o que se tenta fazer com todos os tipos de manipulações, mutações e invenções." ${ }^{17}$

Em sua grande maioria a arte contemporânea se submete ao regime de operações mentais que abrigam metáforas, que encontram correspondências no campo visual, como por exemplo, a cor branca correspondendo ao vazio, ao invisível. É desse modo que Cauquelin estabelece uma relação entre os elementos incorporais dos estoicos e a arte contemporânea. $\mathrm{O}$ vazio é apenas um desses elementos e diga-se muito pertinente.

De algum modo a velha pergunta herdada dos conceitualistas "isto é arte?" como inerente ao próprio conceito de arte, perde a razão de existir, uma vez que não há mais a necessidade de algo "ser" arte.

15 GREENBERG, Clement. Pintura Modernista. In FERREIRA, Glória; COTRIM, Cecília (org) Clement Greenberg e o Debate Crítico. Rio de Janeiro: Funarte Jorge Zahar, 1997, p.111.

16 Ibidem, p.111

17 CAUQUELIN, Anne. Frequentar os Incorporais: Contribuição a uma Teoria da Arte Contemporânea. São Paulo: Martins, 2008, p.87-88 


\section{A fluidez das formas}

O conceito de dissolução e a temática dos subterrâneos em Piranesi são muito apropriados para pensar alguns aspectos de meu trabalho atual, principalmente aqueles cujo tema aborda as estações do metrô.

Dissolução como algo que se espalha sem "explodir", é mais suave e sutil e por isso carrega uma carga de lirismo.

O cineasta Eisenstein em texto sobre Piranesi ${ }^{18}$ comenta que a grande fascinação que a gravura Carcere Oscura exerce sobre ele é que ela é percebida não como uma dissolução de forma, mas sim do sistema dos meios expressivos. Isso quer dizer que ao invés do frenesi e de uma forte impressão de fúria, temos uma atmosfera de "flutuação lírica".

Faz notar que apesar de o tema escolhido por Piranesi ser forte e opressor, a ideia de subterrâneo ser claustrofóbica e os contornos serem rígidos, a atmosfera da gravura é leve, o ar parece que circula por entre as colunas e suas formas são maleáveis.

Há movimento em várias direções e transparência, apesar das sólidas construções. Um acúmulo de perspectiva e justaposição faz com que ocorra ali um movimento centrífugo. Ainda que cada detalhe dessa passagem em perspectiva vertiginosa seja em si mesmo naturalista.

"Em Carcere oscura a concretude é mantida enquanto os meios de representação "voam além": a linha se desintegra em cascata de pequenos traços; a planaridade da forma, suavizada pela luz, flui para o espaço, a precisão de facetas é absorvida nos contornos fluidos da forma". ${ }^{19}$

O que Eisenstein observa em Piranesi é o que me interessa na representação visual: "uma pedra não é mais uma pedra, mas um sistema de ângulos e planos intersectados em cuja encenação a base geométrica de suas formas explode".

Em meus vídeos vejo a possibilidade para a pintura porque eles me instigam à dissolução da imagem. As perspectivas, as formas, a luz e a cor que são elementos da realidade, passam por filtros, ou seja, são vistos por uma lente e depois vão para tela e programas de um computador.

Alterações ou deformações me induzem também a uma desconstrução, onde muitas

Piranesi, “Carcere Oscura”, 1750 água-forte, 35,6 x 23,2cm.

18 EISENSTEIN, Sergei. Piranesi or the Fluidity of Forms. In: TAFURI, Manfredo. The Sphere in the Labyrinth. AvantGardes and Architecture from Piranesi to the 1970's. MitPress, 1990. 
vezes os elementos representados não são mais identificáveis, como se as coisas, as figuras e o mundo concreto se dissolvessem.

\section{Barra Funda Rosa e Barra Funda Azul}

Págs. 82 e 83
Nestas duas pinturas se destacam a luz e o movimento.

Elas partem de um vídeo que realizei na estação Barra Funda em São Paulo, com a atenção despertada pelo espaço arquitetônico e pelo grande fluxo de pessoas que por lá trafegam.

Trata-se de uma imensa passagem que une dois pontos de uma avenida cortada por uma ferrovia. No meio desta passagem há a entrada para o metrô e para a estação rodoviária.

A tomada é subjetiva e causa a impressão de que a multidão caminha em direção ao espectador. O movimento vem do fundo, como em um dos primeiros filmes da história do cinema, A Chegada de um trem, de 1895 e autoria dos irmãos Lumière.

O teórico de cinema Jacques Aumont afirma que um dos traços mais surpreendentes deste filme é o enquadramento: "eficaz em relação ao tema filmado". ${ }^{20}$

O efeito de centralização, que é aquele enfaticamente reforçado pelo movimento do trem, da perspectiva, nos é mostrado na forma de expansão a partir do centro, “onde toda a prática da perspectiva linear acostumava o olho ao trajeto inverso, das bordas para o centro (o vocabulário diz bem: o ponto de fuga é aquele onde, logicamente, o olho chega no fim do percurso). "'21

A borda do quadro tem um papel importante aqui. O toque de gênio dos irmãos Lumière foi ter deixado a imagem transbordar. As pessoas na estação ultrapassam o limite e é graças à atividade nas bordas da imagem que o espaço parece se transformar constantemente.

Em Barra funda rosa, nota-se esse transbordar principalmente através das figuras e das placas logo acima delas. A figura da direita parece que quer entrar na cena, enquanto a da esquerda quer sair. 
Outra intenção foi criar um contraponto na representação da luz natural que entra por espaços vazados do teto e as lâmpadas brancas fluorescentes das luminárias. As últimas formam linhas marcantes que reforçam a construção perspectiva da composição.

Como em outras pinturas com cenas interiores, a cor branca representa a luz artificial e é carregada de matéria, tinta, textura. Essa ênfase é para destacar o elemento "luz", tornando-o mais presente, mas ao mesmo tempo criando um paradoxo: representar o que tem de mais impalpável e etéreo com a matéria viscosa e pastosa da tinta a óleo.

A luz nas minhas pinturas tem uma função atmosférica, delimita regiões que são diversamente significantes na imagem e iluminam o quadro ora por inteiro, ora por zonas.

Aumont afirma que existe um problema duplo da iluminação e da luz em pintura. Por um lado cria-se uma mise en scène, já que a iluminação é um poderoso meio dramático e expressivo, mas também, como ela é pensamento, é construída. ${ }^{22}$

Como reproduzir uma "matéria" diáfana e impalpável com um material que a princípio não se presta bem a isso, ou seja, como transformar pigmentos coloridos sobre um suporte sólido, em luz?

A luz pictórica é sempre uma ideia de luz, o que na verdade mais importa em pintura é a cor. A luz banha os objetos e as figuras criam o espaço. Apesar de ser atmosférica é a cor que define o estímulo dessa atmosfera. Nossa herança histórica mostra que existem efeitos e valores da cor: o simbólico, o fisiológico e o psicológico.

\section{O inacabado}

Nas áreas que representam a luz natural que entra pelo teto, através da estrutura em "shed" da cobertura, o fundo da tela não foi pintado e é evidenciado . Pela falta de textura de tinta, o branco do fundo integra-se com a pintura, porém a ausência de matéria torna-o uma espécie de buraco.

Paradoxalmente, esse "inacabado" completa o quadro. Desse modo ele não sig-

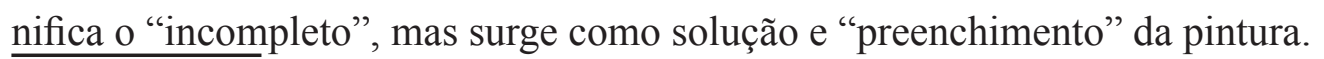


O modo como apareceu já constata a ideia. (Teria pintado de branco porque costumo representar assim a luz branca artificial). No processo de trabalho deixei essa área para pintar no final e, num determinado momento, acreditei que aquela área não devia receber tinta.

O contraste de textura das duas áreas que representam a luz, fez com que surgisse uma relação interessante entre os modos de representação na pintura do mesmo motivo, com a diferença que um vinha de uma fonte natural o outro artificial.

Normalmente deixo uma área "em branco" só quando desenho. Para a minha pintura foi um elemento novo inserido.

O "inacabado" usado como técnica também quer ressaltar o processo da pintura: pinceladas soltas e evidenciadas, falhas pela rigidez da superfície seca, a maneira espontânea, rápida, solta, etc. Não deve ser artificial, ou seja, imitado, parecendo um esboço. No caso dessas duas pinturas, isso não existe. Não é para "parecer" casual é para "ser".

A ideia de vazio aparece não como sinal de "espontaneidade", mas como área não pintada intencionalmente. Já as pinceladas soltas, os escorridos, os borrões, as manchas, etc., são espontâneos, inesperados. Às vezes pinto por cima de alguns escorridos, com o objetivo de eliminá-los por serem excessivos.

O inacabado também traz uma superfície diferenciada no plano da pintura. Em alguns momentos encontra-se o empasto em outros a transparência causada pela tinta rala.

\section{Espaço e tempo}

Barra funda rosa e Barra funda azul são duas pinturas que representam o espaço com uma ênfase na estrutura metálica da cobertura típica de grandes pavilhões.

As áreas pictóricas são bem detalhadas: uma infinidade de variações cromáticas, o uso de cores vibrantes em tons de azuis e rosa e construções lineares, que necessitam de extrema atenção e precisão técnica. 
O tempo, simbolicamente representado pelo relógio em posição central, no meio das linhas do ponto de fuga, está associado ao conceito de movimento, deslocamento e transformação.

As linhas diagonais dos pontos de luz artificial além de seu papel construtivo contribuem para a ideia de rede, devido ao emaranhado de diagonais remetendo metaforicamente à rede do mundo cibernético.

Redes virtuais e tempo são elementos importantes no mundo contemporâneo. A figura da esquerda em Barra funda rosa representa o solitário urbano.

Em Barra funda azul existe a ideia de uma interrupção do fluxo da multidão, representada pela figura em primeiro plano, à direita. Ela cruza os transeuntes e observa algo que ficou para trás.

\section{Retrato e devaneio}

Um dos meus temas é a figura humana que se mostra isolada, introspectiva, em estado de absorção. Não são retratos no sentido usual da palavra - aqueles que relacionam as semelhanças de um sujeito a sua representação - mas ideias, associações e experiências em relação à representação de figuras humanas que observo a partir da imagem fotográfica.

No ateliê, a decisão por uma cena acontece como um insight. Ao assistir o vídeo e observar cuidadosamente as mudanças mínimas de movimento e expressão fisionômica, avançando e retrocedendo o filme várias vezes, "encontro a pessoa" que será retratada em um frame.

$\mathrm{Na}$ série atual a figura se apresenta em contextos reconhecíveis: o metrô e as ruas de cidades grandes. Penso que o clima do metrô, o confinamento num espaço reduzido e o tempo de espera obrigatório em função do deslocamento é o que acrescenta às pessoas o olhar e a atitude tão diferente dos habituais retratos.

Na pintura Três procurei realçar o estado de ensimesmamento em uma típica cena urbana. 
Sentados em um banco de metrô, três passageiros são representados lado a lado, sendo que em apenas um se vê o rosto por inteiro. A barra de apoio que sai do banco divide o espaço em dois: tem-se uma imagem espelhada, a figura de costas se assemelha com a figura principal.

A figura central parece estar entretida com alguma coisa, mas poderia estar simplesmente dormindo. Não se sabe ao certo, mas uma atmosfera melancólica ou uma situação de tédio e vazio prevalece.

A apresentação (pintura) e a representação (descrição da cena) convivem separadas e juntas ao mesmo tempo sobre a superfície plana do quadro.

Enfatizei a pincelada, o gesto e a viscosidade da tinta a óleo sobre a superfície da tela como uma maneira de mostrar a materialidade da imagem.

Na pintura, diferente da imagem inicial, não existe o momento único; a imagem é construída de sequências de ações bem definidas e lentas.

Nem sempre represento pessoas como elas se apresentaram na realidade, muitas vezes elas só me sugerem um estado psicológico. Vemos aquilo que queremos ver. A imagem que capturo representa o instante em que a figura se mostra em uma "pose" interessante para aquilo que eu buscava, no caso, figuras entretidas com seus pensamentos, ainda que no decorrer do processo ocorram mudanças.

As áreas de cor movem- se lado a lado como se estivessem lá só temporariamente, comandadas por uma agitação contínua de mudanças de relações. Os contornos difusos, os resíduos não especificados das formas e as partes do quadro com aspectos não acabados são como rasgos e cortes nas montagens.

Opto pela gestualidade acentuada, não para evitar que o observador se confronte com uma pintura realista, ou chamar a atenção somente para a "pintura pura", mas para simplificar e dar expressividade para aquilo que é captado pela câmera.

As pinceladas diretas e rápidas são econômicas e querem captar o fugidio. A pintura não quer ser ilusão, mas representar um sentimento, uma expressão contida no rosto, remetendo ao tema da solidão das grandes cidades. 


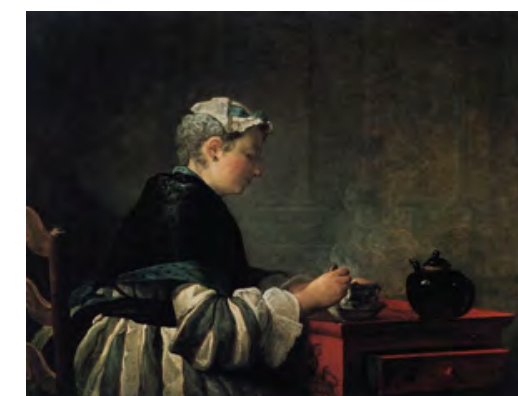

Jean-Baptiste-Siméon Chardin, Uma senhora tomando chá, 1735, óleo sobre tela, 81 x $99 \mathrm{~cm}$.

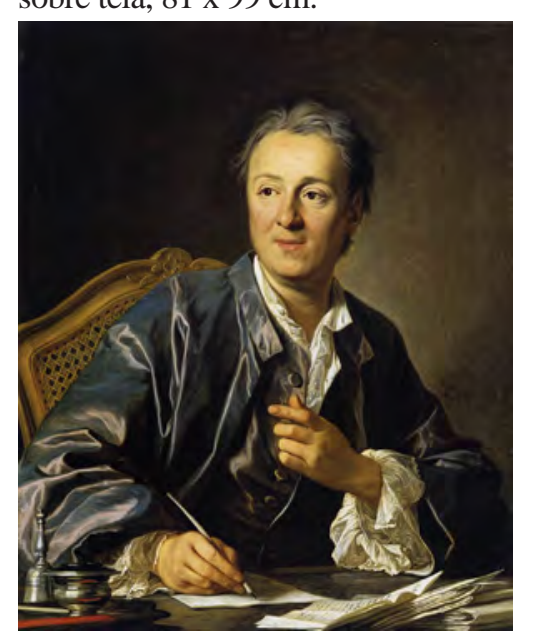

Louis-Michel Van Loo, Retrato de Diderot, 1767, óleo sobre tela, $81 \times 65 \mathrm{~cm}$.

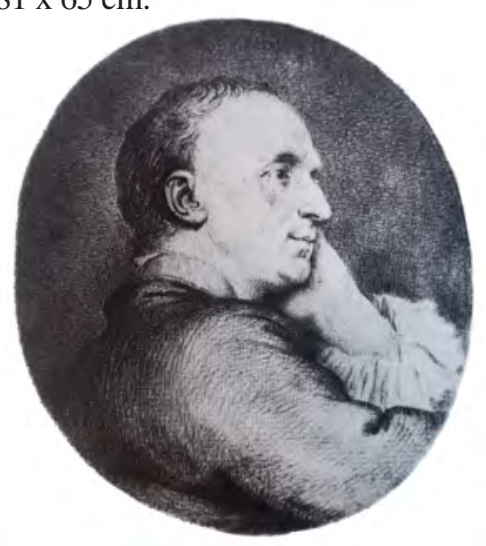

Garand, Retrato de Diderot, 1760, gravura em metal.
O historiador americano Michael Fried trata dos conceitos de absorção e teatralidade nas diferentes relações entre o retrato e seus espectadores, estabelecendo alguns pontos em comum com minha pesquisa.

Fried identifica um gênero na pintura francesa do século XVIII que representa pessoas imersas em seu próprio mundo, seja através de atividades individuais ou em seus pensamentos.

Um exemplo seriam as figuras de Chardin que não se mostram conscientes da construção da imagem e nem da necessidade da presença de um observador. Isso é justamente o oposto da teatralidade. São figuras que não estão atuando, mas apenas sendo elas próprias. Ao tratar da relação pintura-observador, o autor baseia-se nos comentários de Diderot a respeito dos Salons parisienses e afirma que para o filósofo era necessário que o conjunto do quadro ignorasse de forma ativa o espectador, tornasse neutra a sua presença.

É interessante observar um retrato que Louis-Michel Van Loo fez do próprio Diderot e a crítica que o filósofo faz dele.

Seu ar afetado, segundo Diderot atribui-se à presença da inquieta Madame Van Loo no ateliê enquanto o quadro estava sendo pintado.

Teria sido melhor, escreve Diderot, ter deixado o modelo sozinho e "perdido em seus devaneios. Dessa forma, sua boca teria se entreaberto, seu olhar distraído teria se focado em algum ponto distante, os trabalhos de sua mente profundamente pré ocupada teriam se manifestado em seu rosto, e o pintor teria feito algo belo". ${ }^{23}$

O retrato poderia ser mais natural, produto de uma relação especial entre o modelo, e o pintor e consequentemente entre a pintura e o observador, pois na medida em que o modelo está absorto em seus pensamentos, ele parece alheio ao fato de estar sendo observado. Daí a defesa da necessidade de tratar o observador como se ele não existisse.

Já na gravura de Garand, o filósofo afirma que pôde se reconhecer nele e não pelo fato de se ver representado num estado meditativo ou sonhador e achar estes mais próximos de sua natureza, mas por ter sido esta uma "bela escolha" do pintor, o que torna o retrato uma obra de arte.

23 FRIED, Michael. Absorption and theatricality: painting and beholder in the age of Diderot. Chicago: University ofChicago Press, 1980, p.112. 
Fried sugere uma conexão íntima entre o retrato do devaneio e a ficção de solidão de ambos, do próprio modelo e do seu retrato, portanto a pintura, em relação ao observador. De fato propõe uma espécie de ausência do pintor no "fazer" da pintura deixando o retratado parecer mais autêntico, mas também e até mais importante, de modo que a ficção de que ninguém está ao lado da tela possa ser estabelecida desde o início.

É importante lembrar que em meados do século XVIII na França, o retrato era um gênero menor aos olhos de muitos críticos de arte que alegavam exigir mais o exercício de habilidades meramente mecânicas do que da imaginação pictórica. Além de haver uma teatralidade inerente ao gênero que o deixava carente dos recursos necessários para adequarse à demanda de que uma pintura deveria negar ou neutralizar a presença do observador.

Por esse motivo, retratar pessoas como se estivessem absortas em pensamentos ou em ações foi uma estratégia adotada pelos pintores a fim de superar essa limitação.

O que Fried mostra em seu estudo é que Diderot tinha uma concepção alternativa de pintura ao considerar que o espectador devia ficar de fora, ou melhor, ser desconsiderado. Além disso, a ausência ficcional do espectador na obra pictórica fazia com que ela se remetesse para si mesma representando assim a reivindicação da autonomia da forma plástica.

Voltando às minhas pinturas, posso dizer que minha escolha por "figuras absortas" no metrô também está intrincada com essa vontade de representar as características da alma humana, mas a forma de reivindicar a autonomia da pintura é diferente. A massa de tinta óleo e as pinceladas gestuais se contrapõem com o conteúdo da imagem do vídeo criando uma dialética entre a imagem digital e pintura, entre estado da alma e matéria.

Não quero só aquele "retrato do devaneio" que Diderot defendia como um bom retrato porque era uma "bela escolha" do artista. A ideia de tornar ficcional a presença do pintor e do observador não é meu objetivo. Minha pintura reivindica o observador, quer se relacionar com o espaço que a circunda, e comigo mesma. Em cada "retrato" me vejo um pouco.

Uma das diferenças no meu trabalho, em relação ao conceito de absorção de Fried e as "figuras de Diderot" remete ao toque de teatralidade que se observa no aspecto formal 
da pintura. Por exemplo, nota-se um exagero na saturação e no contraste de cores e uma ênfase na temática da luz artificial dos ambientes representados.

Nem sempre as figuras que capturo nas ruas e no metrô estão absortas de fato. Escolho o momento em que ela se porta como se estivesse nesse estado, no trabalho de pósfilmagem, no computador. Este consiste em pausas, desaceleração do vídeo, contrastes de luz, mudanças de cor, etc.

Em uma época acreditava-se que a "verdade" sobre uma pessoa podia ser revelada se ela fosse pega desprevenida, assim, se tivesse a consciência da câmera, inevitavelmente teatralizaria sua auto representação. Hoje pelo fato de vivermos rodeados de câmeras de segurança, de estarmos sempre registrando nossas "passagens" através de câmeras portáteis, identificado nossas páginas da internet com nossos "retratos", enviando para as redes sociais nosso cotidiano, essa verdade é questionável.

Por essa razão, não busco no metrô figuras que se desfazem de suas máscaras ou que são mais "reais" ou mais próximas da "verdade" porque estão inconscientes da câmera. Na verdade, as pessoas "sempre usam maquiagem".

O poeta e crítico Charles Baudelaire tinha desprezo por artistas envolvidos com a natureza em si mesma, que tinham um gosto exclusivo pela "verdade" e que oprimiam o gosto pela beleza considerada por eles "sinteticamente" orientada. Chamava-os de moralistas. Ele elogiava a maquiagem que "tem por objetivo e por resultado fazer desaparecer da tez todas as manchas que a natureza nela injuriosamente semeou [...]" e que ao "criar uma unidade abstrata na textura da pele, unidade que, como a produzida pela malha, aproxima imediatamente o ser humano da estátua, isto é, de um ser divino e superior $[\ldots]]^{\prime 24}$

Assim justifico o uso dos recursos tecnológicos no meu trabalho, como o primeiro passo, rumo a uma pintura que também elogia a maquiagem. A minha escolha em capturar imagens de pessoas no metrô explica-se pela comodidade de estar próxima a muitas 
delas e pela oportunidade de olhar para diferentes tipos de rostos por um tempo razoavelmente longo.

\section{Só, no vazio}

Em alguns de meus "retratos" as figuras parecem simplesmente perdidas num vazio, propiciado pelo cansaço, espera e tédio da vida cotidiana. Talvez nem estejam em estado meditativo e resta esta incógnita que para o meu trabalho é importante.

Págs. 89

Em Só, no vazio retrato uma moça que se sentou em minha frente no vagão do metrô enquanto eu a filmava secretamente. A câmera capturou um detalhe da janela e da parede do vagão que me chamou a atenção quando mais tarde a observei no vídeo. (É importante ressaltar aqui que a câmera que utilizo é embutida em uma caneta, o que me garante filmar sem que as pessoas notem, mas ao mesmo tempo não me permite controlar precisamente o enquadramento da cena.)

Existia um foco na quina da janela que estava em primeiro plano, mas a figura ao fundo saltava para frente, em decorrência da luz artificial e dramática que rebatia em seu rosto e em seu braço. Configurava-se um contraste entre uma área plana e monótona e outra modulada por pinceladas curvas e sobrepostas.

Uma vez que para mim os dois planos têm igual importância, na pintura procurei fazer com que tons de rosa e o vermelho contrastassem com o branco e o vinho quase preto, usando-os tanto na figura como no fundo. Isso fez com que a atmosfera fria do metrô se tornasse mais aconchegante. O olhar da moça retratada é profundo e tem algo de artificial também.

Mais uma vez me reporto a Baudelaire e seu "Elogio da maquiagem":

"O vermelho e o preto representam a vida, uma vida sobrenatural e excessiva; essa moldura negra torna o olhar mais profundo e singular, dá aos olhos uma aparência mais decidida de janela aberta para o infinito [... [",25

É interessante notar que mesmo não havendo hierarquia entre os planos, a 
expressão da figura é o que mais chama atenção no quadro. Desta maneira transforma-se em um "quase-retrato".

Já havia feito pinturas com este mesmo tipo de composição. São retratos em que a figura se desloca para um canto do plano do quadro deixando um fundo vazio ao lado.

Em pinturas recentes este vazio está permeado pelo significado do intervalo: o espaço que existe entre as pessoas e as coisas; uma espécie de vácuo. Em termos de conteúdo narrativo pude reforçar o tema da solidão ou do isolamento nas grandes cidades.

\section{Camisa listrada}

Em Camisa listrada a figura sugere estar segurando e olhando para algo, talvez um telefone celular. Procurei fazer com que as mãos não ficassem tão evidentes enquanto forma, mas que demonstrassem uma manipulação.

Aquilo que carrega é o que o torna ausente daquele espaço que habita. É o que se pode definir como um objeto com poder absortivo. O que o interessa é o que menos interessa ao espectador. Observar alguém observando é perceber o quanto aquele ato pode nos remeter ao sentido de ainda hoje olharmos para uma pintura.

Quero mostrar que uma imagem construída manualmente, artesanalmente, pode nos levar a uma reflexão sobre o que é esse entretenimento do olhar: uma relação entre o mundo virtual e o real.

As pessoas no espaço público entretêm-se e se comunicam através de seus aparelhos eletrônicos com pessoas que estão em outro lugar. Essa condição muda a relação com o espaço-tempo e consequentemente o olhar para o mundo.

Voltando à leitura da pintura, a figura está absorta e desloca-se no espaço gerando movimento: dois estados facilmente identificáveis em grandes cidades, onde pessoas costumam fazer coisas diferentes simultaneamente.

O espaço onde o menino se encontra é indefinido. Não é possível dizer que há uma 
escada rolante, nem que está em uma estação de metrô. Na verdade é um espaço 'semiinterno': uma entrada para uma estação de metrô onde também se situa um terminal de ônibus. A luz intensa que vem do lado esquerdo da pintura é a luz do dia.

O que mais me interessou nesta imagem quando congelei a cena foi essa indefinição da ação do menino. Nem tanto para refletir sobre o grau de absorção, mas para deixar enigmático o ato. Sendo assim o tema deixa de ser uma cena com um rapaz no metrô, mas uma figura estranha num espaço ambíguo.

Quanto aos aspectos formais, tive o interesse de contrapor três tipos de azuis que parecem brigar entre si. Sendo assim, existe nesta pintura, certa dissonância quanto à cor.

Procurei dar profundidade acentuando linhas diagonais que representam grades de uma passagem onde se encontram escadas e rampas. O branco representa a luz intensa do dia contrastando com a luz artificial do espaço interno. Mas, a fonte de luz artificial também é representada pela cor branca, que forma uma espécie de "buraco" no fundo escuro.

A parte superior, azul marinho quase preto, se planifica e os retângulos claros, sendo dois deles brancos, tornam-se elementos geométricos sobre uma superfície plana. Se isolássemos essa área do quadro e retirássemos dali a figura humana, teríamos uma pintura abstrata.

Isso acontece muitas vezes em meu trabalho e é uma questão sobre a qual costumo refletir: a dicotomia entre a abstração e a imagem realista.

A figura se destaca por meio de duas coisas: a cor viva e a pincelada marcante. Os tons de pele, que se vê nas mãos e braços são quentes: marrom e beges alaranjados. A camisa com listras vermelhas "protagoniza" a pintura, por isso o título.

O vermelho "grita" e se destaca do espaço com predominância de cores frias. Bem ao fundo, uma forma quadrada, rosada, busca um diálogo. Vem para frente, mas, ao mesmo tempo é um ponto de fuga, está longe.

O verde claro, ácido, acima da cabeça da figura forma uma espécie de aura. Está no mesmo grau de intensidade de saturação do vermelho da camisa e contrasta com os tons esverdeados na parte superior direita. 
Diferente de outras pinturas atuais, a figura não se mistura totalmente com o fundo. Entra em conflito com ele, pode-se dizer, uma vez que as pinceladas do fundo branco a contornam ou são por ele interrompidas. Figura e fundo estabelecem uma espécie de jogo. De algum modo, a cor escura "suja" a cor branca, mas é justamente isso que traz a ideia de movimento.

Busco frequentemente esse efeito em minhas pinturas. É como mostrar um "fazer e desfazer" constante, ou o borrar "sem querer" que pode significar tanto a pincelada ao acaso como deixar a mostra um "descontrole" da mão.

Existe a intenção de deixar explícitos as "incertezas" da pintura e o embate entre a espontaneidade e a rigidez. Justifica-se assim a escolha da técnica do molhado sobre o molhado: as duas cores se fundem, borram.

\section{Pinceladas (que deixam rastros)}

Os rastros que deixo, mais do que a intenção de causar movimento ou dramaticidade, buscam atingir uma homogeneidade na superfície. São gestos expressivos, mas não necessariamente expressionistas, como já havia afirmado.

$\mathrm{O}$ ato de pintar está ligado ao desejo de produzir reflexões, a respeito dele mesmo.

Minhas pinceladas podem se referir a artistas ou movimentos artísticos sem que isto seja citação ou apropriação. Faço coisas que estão no meu universo imagético. Quantas vezes passo o dia olhando imagens digitais, reproduções fotográficas em livros e esqueço que existe um mundo chamado "real" lá fora... - Mas isso também é real!

Existe um desejo de juntar pinceladas. O contraste entre elas, o jogo formado, em diálogo com a cor é o que faz o meu trabalho, cria unidade.

Certa vez, li as notas de Gerhard Richter e deparei-me com a afirmação: "Eu borro (verwischen) para igualar tudo, para tornar tudo igualmente importante e igualmente desimportante." 
Essa frase me faz pensar em minhas próprias "pinceladas rastros", porque soa equivalente. Não borro como Richter, mas transformo a imagem que vejo e deixo-a menos "literal", mais "embaçada" ao interpretá-la como pintura.

A figura se mistura com o fundo, o que torna "tudo mais importante ou desimportante”, porém, as pinceladas estão de alguma maneira contando uma "história", ou seja, têm uma razão de estar nesta ou naquela direção, mesmo que isso seja difícil de ser explicado em palavras. Elas estabelecem uma espécie de diálogo com a imagem.

Pág. 91

Em $O$ Beijo, há dois tipos de pinceladas: aquela que deixa rastro e mistura as cores e aquela que é plana, chapada. A primeira busca passar a sensação de movimento, a segunda, a inércia da matéria e sua potência construtiva.

Em áreas referentes aos corpos, principalmente o da direita, constata-se a "pincelada que deixa rastro". É o corpo que se movimenta e que dá o beijo. Seria então essa pincelada a melhor maneira de representar o movimento capturado?

Refletindo sobre o meu processo de trabalho, noto que as "pinceladas rastro" não são feitas de impulso. São antes, colocadas em áreas específicas de cor no quadro. A cor define onde a pincelada vai se misturar com outra, portanto ela vem a posteriori. Surge por cima de uma área plana, estrategicamente na roupa da figura que se movimenta. Existe a relação da matéria do tecido com a fluidez do movimento do corpo.

Na parte superior estão as pinceladas mais planas e densas de matéria. Um pequeno "rastro" nota-se logo acima da cabeça da figura centralizada. Um contraste de claro e escuro também se faz evidente. As mais claras formam um retângulo e sugerem um movimento de ascenção, como se o corpo desse um salto para dar o beijo. Isso torna a figura mais leve, etérea. Conclui-se que uma pincelada que deixa rastro transmite a ideia de movimento e leveza.

Pág. 92

No retrato Pai e Mãe Antes, as pinceladas na parte superior, representando as árvores, são curvas e passam a ideia de movimento. As cabeças das figuras pertencem aos elementos representativos mais "fluídos". 
Nem sempre as direções das pinceladas criam relações literais com os elementos da figuração. Muitas vezes representam um fundo neutro em um retrato ou em uma cena. Cumprem o papel de trazer um dinamismo de campo e cor. Trabalham por contraste de figura e fundo através de cores e gestos.

Acredito que minha pintura é tradicional no que se refere à representação da realidade. Mas, ao mesmo tempo, não são realistas, pois a realidade de onde vêm não é o que predomina no final.

A pintura transforma essa realidade fotográfica e cria outra imagem. Na verdade uma imagem-objeto. A tinta e o tecido da tela juntamente com a pincelada e a cor, transformam toda a realidade de onde partiu. Pode ter sido um pretexto, mas talvez mais do que isso, um estopim. 


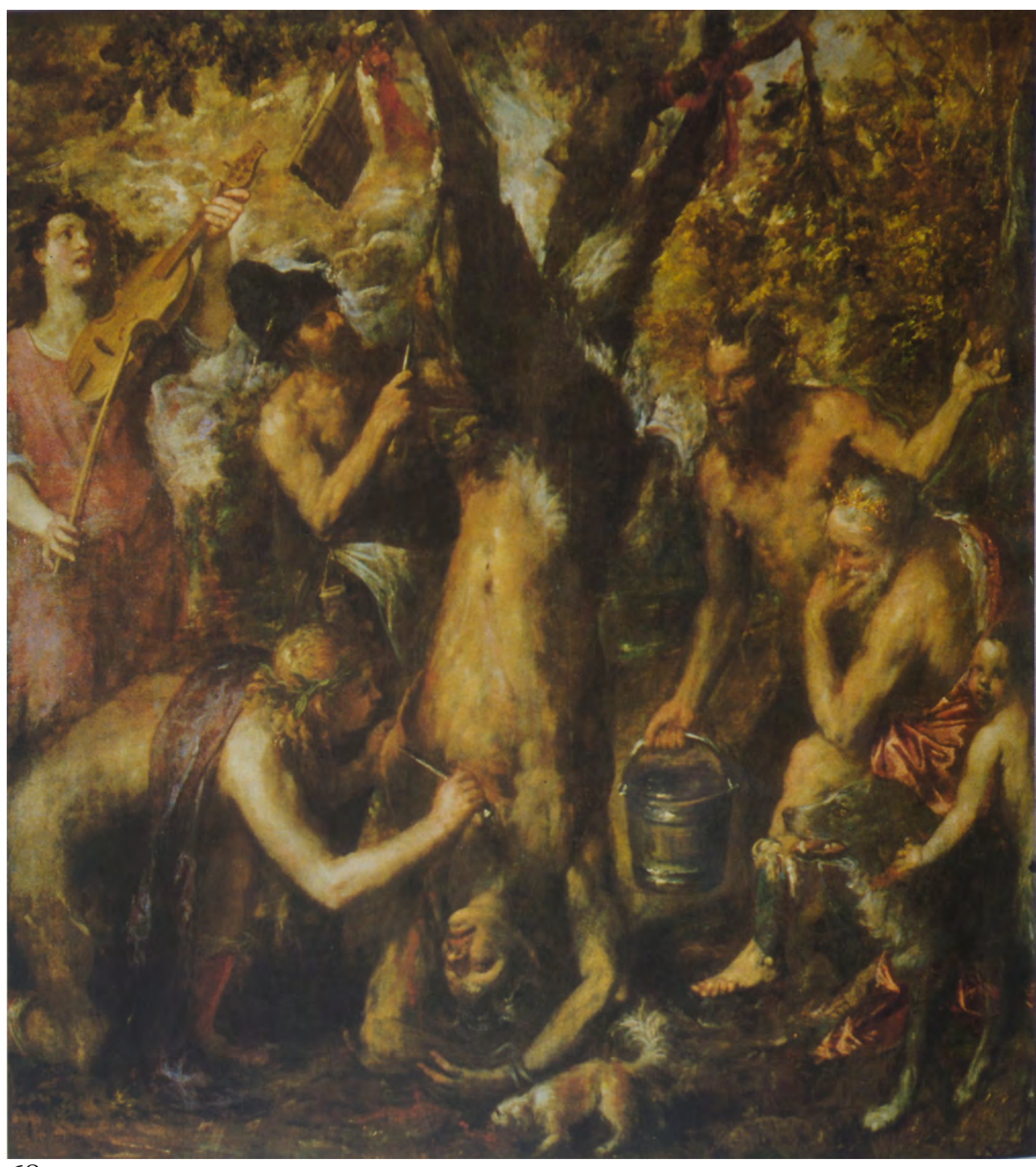

Ticiano, O esfolamento de Mársias, óleo sobre tela, (1570-1575) 


\section{PELE E ENTRANHAS: UMA CONCLUSÃO?}




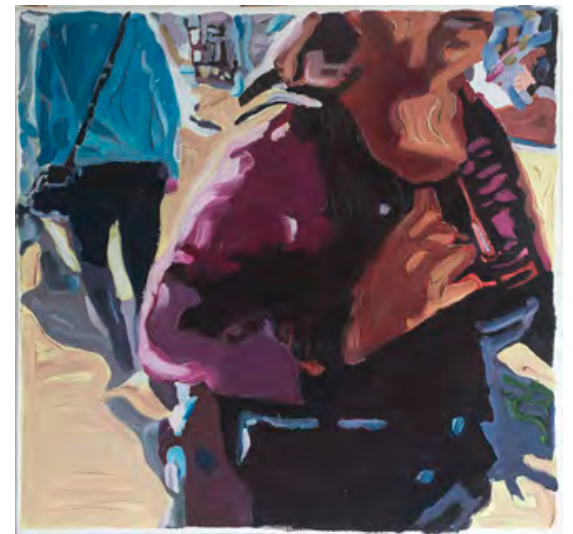

fig. 1 - Andradas II, 2011, óleo sobre tela, $69 \times 67 \mathrm{~cm}$

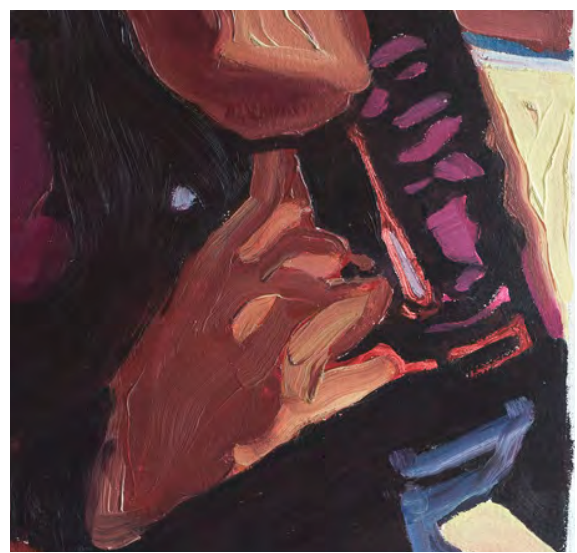

fig. 2 - Andradas II, detalhe

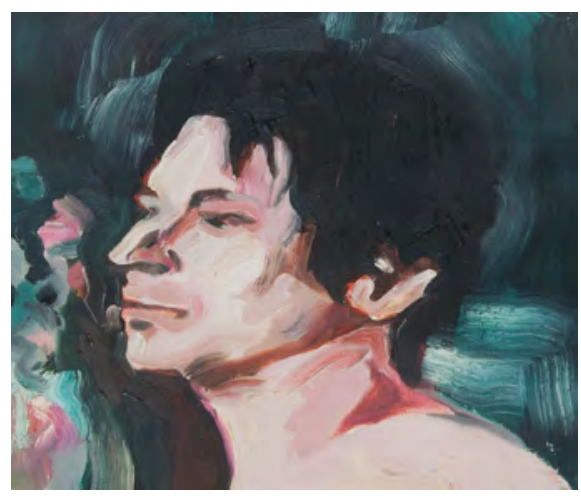

fig. 3 - Questão humana, 2010, óleo sobre tela, 81 x $67 \mathrm{~cm}$ - detalhe

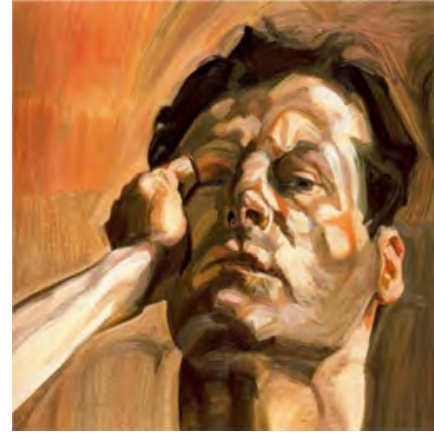

Lucien Freud, Man's head

(self portrait), 1963, óleo

sobre tela, $53,3 \times 80 \mathrm{~cm}$

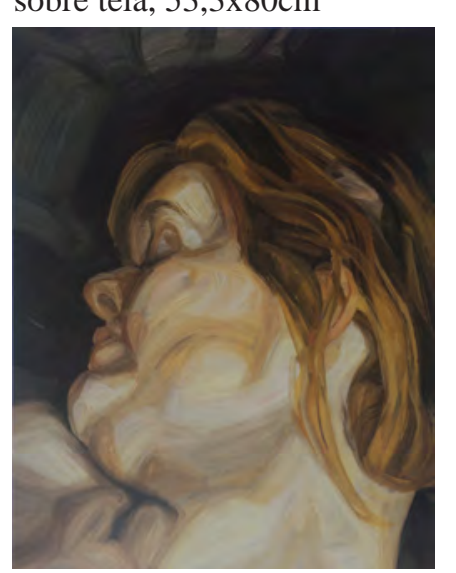

Lucien Freud, Sleeping head, 1962, óleo sobre tela, $66 \times 50,8 \mathrm{~cm}$

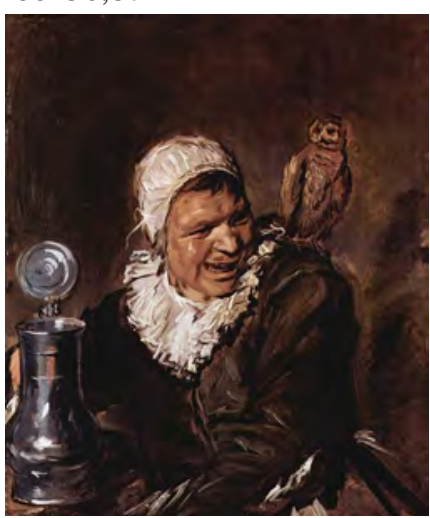

Frans Hals, Malle Babbe, 1634, óleo sobre tela,

$75 \times 64 \mathrm{~cm}$ 
Uma questão plástica no meu trabalho refere-se à contraposição das linhas curvas e maleáveis do corpo humano com as linhas duras e retas do ambiente urbano.

Como criar um diálogo entre elementos geométricos e orgânicos da representação e atingir uma unidade pictórica?

Minha opção foi buscar na representação do espaço uma aparência tão orgânica como o interior de um corpo humano.

E m algumas pinturas priorizei um enquadramento mais fechado, dando destaque ao aspecto corpóreo da figura, criando uma possível relação com as dobras dos tecidos da vestimenta. Existe aí, evidentemente, uma valorização do detalhe.

Por vezes, faço perder a referência do objeto, mas me interessa uma fatura que enfatize a matéria, como se fosse necessário na pintura, tatear, para reconhecer o motivo.

A tinta é dirigida com o pincel de pelo de porco, flexível, diferente do toque do pincel de pelo de marta, por exemplo, que segue as formas com uma literalidade obediente.

As marcas são bruscas e parecem cabelos grossos e lisos mostrando sua complexidade como uma força improvisada. A técnica de pintar uma camada de tinta sobre a outra ainda molhada, realça essa rapidez e sintetização da forma. Vejo um parentesco da minha pintura com a de Lucien Freud e Frans Hals, aliás, este último, uma inspiração para o primeiro. ${ }^{1}$ Em meu trabalho também procuro enfatizar o estado psicológico em que as figuras se encontram, sem perder a qualidade de corpo, carne.

O crítico americano Robert Huges em um texto sobre Freud, afirma que é justamente esse senso de protuberância, a elasticidade da forma, aquilo que se consegue com as pinceladas diretas com cerdas duras, que está em consonância com Hals. Como exemplo, cita duas obras: Man's head (self portrait), que mostra o impulso diagonal do antebraço e a mão do pintor contra o queixo e Sleeping head, cujas formas não vistas do resto do corpo, parecem ter sido deslocadas para dentro da inchada bochecha e maxilar, vistos de baixo para cima. ${ }^{2}$

1 HUGHES, Robert. Lucian Freud paintings. London: Thames \& Hudson, 2008, p. 18 
O crítico ainda alega que o trabalho de Freud ganhou uma nova força quando justamente abandonou a modulação dos planos acentuada pelo contorno, à maneira de Ingres, e começou a tratar a superfície da pele como matéria. Isso foi nos anos de 1958 e 1959.

Sobre Sleeping head, Freud afirmou: "Eu ia começar a fazer um nu, quando percebi que poderia fazer isto a partir da cabeça". ${ }^{3}$

Pode-se daí concluir que para expandir a plasticidade, o artista aprendeu a ver a cabeça através do corpo, como um todo e constata-se isso nas suas pinturas dos anos de 1960 a 1970 principalmente.

A partir do meu intenso envolvimento com a representação da figura humana no mundo, pode ser trazido na etapa conclusiva de minha dissertação, um tema clássico na história da pintura desde a antiguidade: o mito de Apolo e Mársias.

O mito pode ser definido como "uma representação coletiva"4 que vem de gerações e pretende explicar o mundo e o homem. Como sua função específica é transformar um sentido em forma ${ }^{5}$, não se pode definí-lo pelo seu conceito, mas pelo modo como ele é dito. Assim, a obra de arte de conteúdo mitológico é uma variante entre muitas possíveis.

No mito de Apolo e Mársias, contado por Ovídio em As Metamorfoses, Mársias é um sátiro que encontrou a flauta desprezada por Atenas e aprendeu a tocá-la. Tornou-se um músico tão perfeito que resolveu desafiar Apolo com sua lira (deus do conhecimento, da música e das artes).

Para a disputa foram convidados para jurados Midas - rei de Frígia, hoje centro da Turquia - e as Musas. O primeiro se pronunciou a favor de Mársias e as Musas a favor de Apolo. O castigo do deus a Midas (aquele que transformava tudo o que tocava em ouro) foi lhe dar orelhas de burro. Já o fauno, foi condenado ao esfolamento e Apolo ao arrepender-se da pena cruel, fez com que de seu sangue nascesse o rio Mársias, em Frígia.

3 Ibidem, p.19

4 BRANDÃO, Junito de Souza. Mitologia Grega, vol.1. Rio de Janeiro: Editora Vozes, 1986, p.36.

5 BARTHES, Roland. Mitologias. São Paulo: Difusão Europeia do Livro, 1972, p.131 
Para alguns este mito simboliza a superioridade da arte grega sobre a oriental, pois a lira é vista como o instrumento com o qual Apolo venceu Mársias. Representa a alta cultura, a harmonia e a beleza ideal. É um instrumento básico da música grega, um elemento da cultura nacional.

A flauta de Mársias é considerada um instrumento grosseiro que não pode acompanhar as canções dos poetas que se esmeravam em tocar e cantar ao mesmo tempo os feitos heroicos. A lenda que atribui o descobrimento da flauta em Atenas é ainda mais antiga e diz que os gregos consideravam a flauta um primitivo "brinquedo de pastor". ${ }^{6}$

Como representava a superioridade do belo sobre o feio, da harmonia sobre a desordem, do sublime sobre o vulgar, o mito de Apolo e Mársias reafirma ainda a preocupação do artista na criação de um mundo ideal e inspirado por Apolo. Na verdade, fixava um tipo de beleza que nem sempre era alcançado, pois muitas vezes se deparava com o mundo real.

Na Renascença, vários pintores se dedicaram a representação deste mito. Tomando Ticiano, como um destes, o que se vê na pintura O Esfolamento de Mársias”, é o momento da punição do fauno.

As figuras estão em pose desconfortável, próximas ao primeiro plano do quadro, criando uma confrontação entre carne e espectador. Pode-se dizer que a obra é uma violência para os olhos. Quem esfola Mársias, com a coroa de louros é Apolo, que segura a faca como um pincel fazendo alusão ao artista. O sangue (tinta) é representado por pinceladas gestuais (informais) que escorre e coagula formando uma massa pictórica.

A pele e a carne na cena mitológica evidenciam um sacrifício e a transformação da matéria, que é consequência de uma ação. O corpo em estado de transformação é assim, uma alegoria da pintura.

Pode-se dizer que Ticiano via em Mársias uma relação de parentesco com sua própria existência. Descreve o esfolamento do fauno como um mistério onde um silencioso ritual pagão 
é consumado. Ninguém grita, não há triunfo, Mársias tolera a tortura como um escolhido. Como uma ferramenta da necessidade, Apolo se aprofunda no processo do sacrifício. ${ }^{7}$

Para o filósofo britânico Richard Wollheim, ${ }^{8}$ essa ligação do corpo ao sofrimento em Ticiano, não significa a perda de conexão entre o corpo e a vitalidade. O sofrimento brutal pode ser interpretado como uma chance para o homem mostrar, através da determinação e do esforço externo do corpo, que pode tirar a atividade da passividade.

Cabe aqui lembrar que a obra é da última fase de Ticiano, que, mesmo em idade bem avançada, buscava vigorosamente uma mudança na sua pintura. A representação do sofrimento do corpo é coerente com a vitalidade presente em seus trabalhos anteriores.

Existe na expressão do rosto do fauno uma aceitação, que podemos interpretar como triunfante: a vitória da alma sobre o corpo só é possível pela vitória do corpo sobre si mesmo.

Já com base no conceito de Primitivismo da arte moderna e no pensamento de Nietzsche, o professor e historiador suisso Beat Wyss, explica que o sátiro precisava ser maltratado para que assim pudéssemos acolhê-lo "sentimentalmente em nosso coração".

“No Primitivismo a civilização condena sua civilidade. [...] O Primitivismo só é possível em consequência do reconhecimento das zonas submetidas da cultura; ele mostra o lado beneficente da colonização. Ao invés de, com uma estreiteza arrogante ficar do lado de Apolo, o civilizado, com consciência de culpa, toma partido por Mársias.",9

Wyss afirma que no Nascimento da Tragédia a divisão estética entre Apolo e Mársias é convertida no binômio Apolo e Dionísio. Esta polaridade foi derivada do desenvolvimento histórico da tragédia grega. ${ }^{10}$ Nietzsche serve-se do otimismo moderno, que acredita na execução final da racionalidade. Sua justificativa pela loucura, pela porção de primitivismo que cada um carrega, tem relação com aquilo que Freud mais tarde, ao criar a psicanálise, toma como base: a supremacia do inconsciente sobre o consciente.

7 Ibidem, p.10

8 WOLLHEIM, Richard. A pintura como arte. São Paulo: Cosac\&Naify, 2002, p.326.

9 WYSS, Beat. op.cit., p.15 
Assim, o mito de Apolo e Mársias seria como o drama original da individuação: Apolo representa o ego que domina e a vitória da consciência sobre o inconsciente, do racional sobre o irracional.

Por isso, não se deve menosprezar na interpretação do mito, que houve um embuste: Mársias foi derrotado porque Apolo conhecia mais truques, podia tocar a lira invertida e ainda cantar ao mesmo tempo, o que era impossível para Mársias com sua flauta. Para dominar o desejo necessita-se da artimanha da razão.

Para Nietzsche a consciência seria não aquilo que origina, mas o que aniquila a arte. $\mathrm{O}$ "eu" que fala ao sujeito está sob a lei da autopreservação, estranha à arte. Esta deveria ter como objetivo não se manter, mas saber se gastar. Só quem vence as tentações de Dionísio torna-se artista e a arte surge não por capacidade de ocultar e delimitar a consciência, mas apesar dela e da lei da autopreservação ${ }^{11}$.

Entre o princípio apolíneo e dionisíaco deve-se buscar uma mistura. Mediante a fricção entre disciplina e desregramento, o pensamento se pulveriza. O artista incorpora ambos: Mársias e Apolo.

Assim, cada tela consolidada é um pedaço de pele que o artista retirou de si, sendo a obra de arte o resultado do equilíbrio destes opostos.

A questão que resta é saber como a obra escapa do perigo que esse equilíbrio representa, ou seja, esse compromisso superficial que faz esquecer a dureza da luta.

No nível da aparência artística vence Apolo sempre. Ele rege as condições para o equilíbrio na obra; é o lado da ilusão que torna a obra visível. O artista é obrigado a fazer da vida um artefato, para que assim se torne visível. Só em trabalhos acadêmicos medíocres ignora-se Mársias. Lá triunfa a dissimulação de Apolo com uma "barulhenta inocência".

"À semelhança de Apolo, o artista faz de sua vitória uma vergonha. Na gruta de Kelainai está a pele de Mársias esticada acima da fonte. A lenda sabe que o fole se movimenta para os tons de uma flauta frígia - como se um arrependimento divino pudesse trazer de volta a pele do fauno". ${ }^{2}$ 
Com relação às minhas pinturas mais recentes, constato que a ideia de fundir a figura com a paisagem está muito próxima da concepção plástica de Ticiano em O Esfolamento de Mársias. A massa é enfatizada, não a estrutura da pintura. O volume das figuras é dado pela variação de tons e de contraste de cores. Os corpos são vistos em si e não em função do movimento - que seria apenas um pretexto para mostrar os corpos no espaço. Os contornos abertos das figuras revelam a noção de pertencimento ao lugar, ou seja, as figuras "vazam" na atmosfera.

Essa alegoria constata e reafirma aquela ambiguidade que sempre foi inerente à arte. Poderíamos defender que o desafio e o sacrifício são elementos do fazer artístico e a consequência deste ato faz gerar a grande indagação humana: como conviver com os opostos?

Como artista, acredito que a pintura se faz do confronto do racional com o irracional: um jogo entre o que é programado e o acaso.

Tomo Santo Agostinho como exemplo do primeiro a abordar os conceitos de corpo e de alma como uma mistura que evidencia a verdadeira natureza humana. Através dela constata-se sua imperfeição.

Vai encontrar nas Sagradas Escrituras, como constata o crítico Lorenzo Mammì, a palavra que procura: carne. Quando o santo se depara com a famosa frase no evangelho de São Marcos "o espírito é forte, mas a carne é fraca", conclui que o espírito aqui não é alma, mas espírito divino que ilumina, e carne indica a natureza humana em sua totalidade, e não apenas o corpo. ${ }^{13}$

Minha pintura busca a representação dessa totalidade: a imagem da figura que é capturada em vídeo se torna matéria na tela de pintura, para se tornar carne. Nesse sentido, parte importante dela é seu aspecto viscoso e denso, que preza a presença, a cor, a materialidade e remete a pele e entranhas. 


\section{ILUSTRAÇÕES}





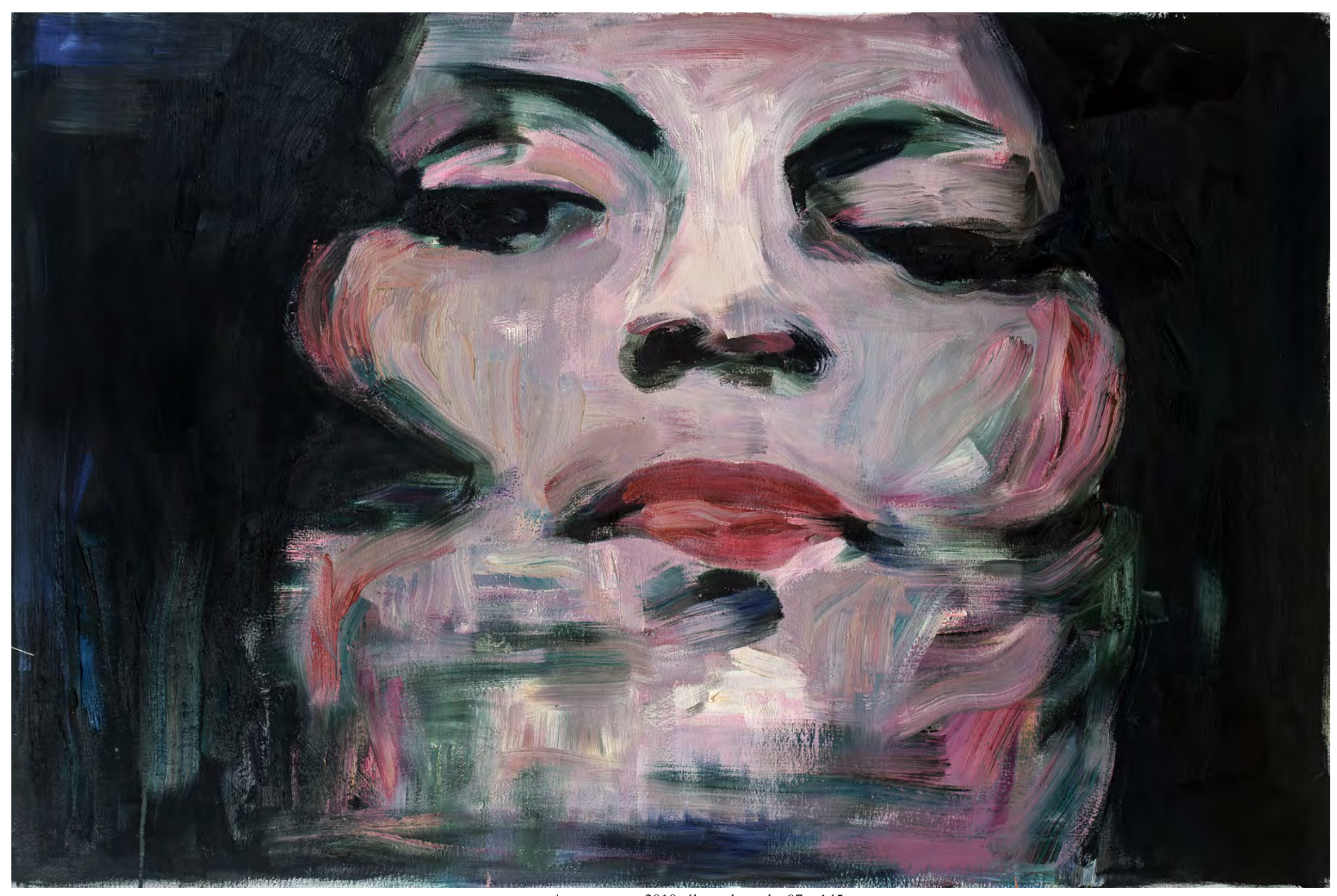




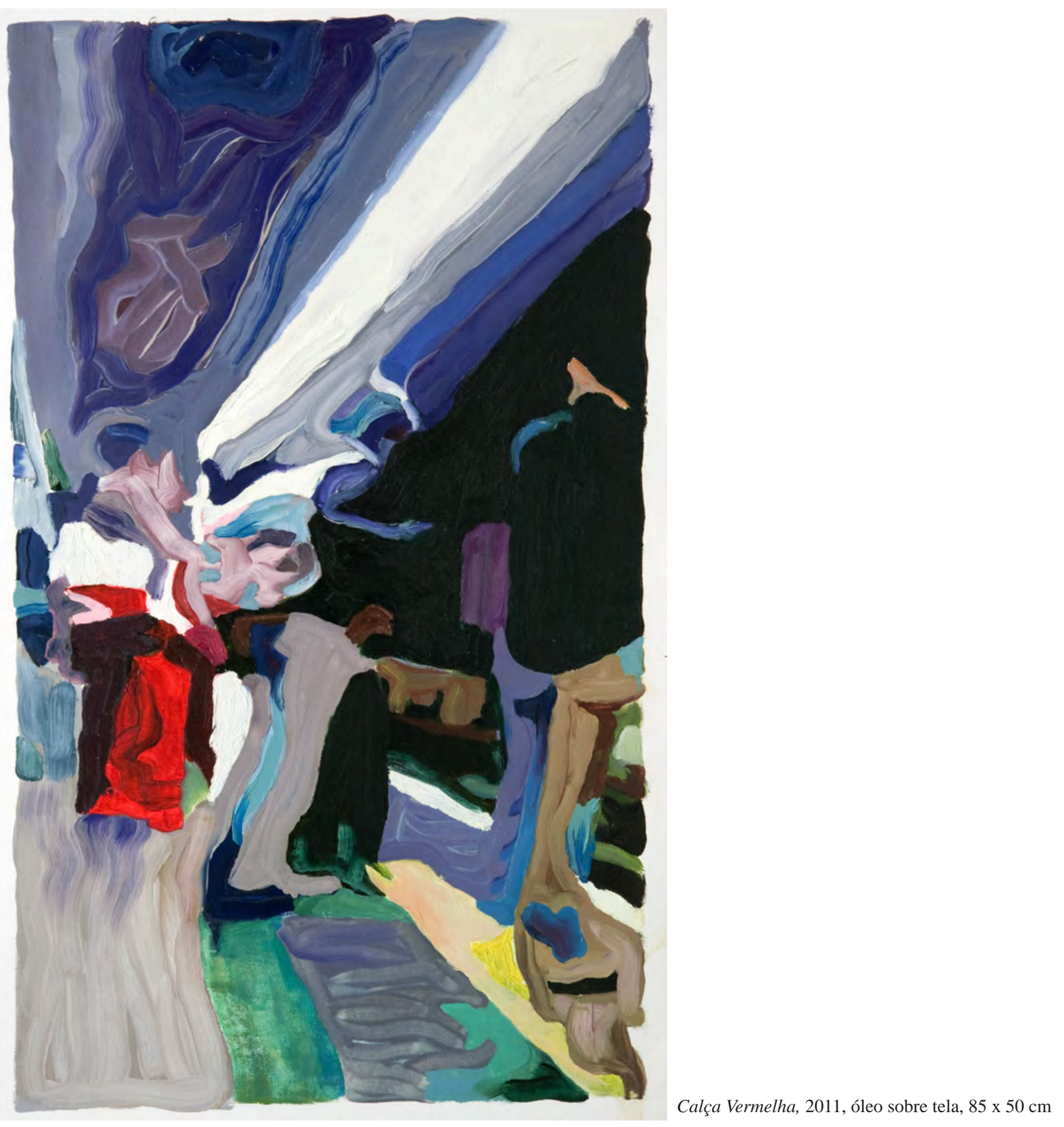




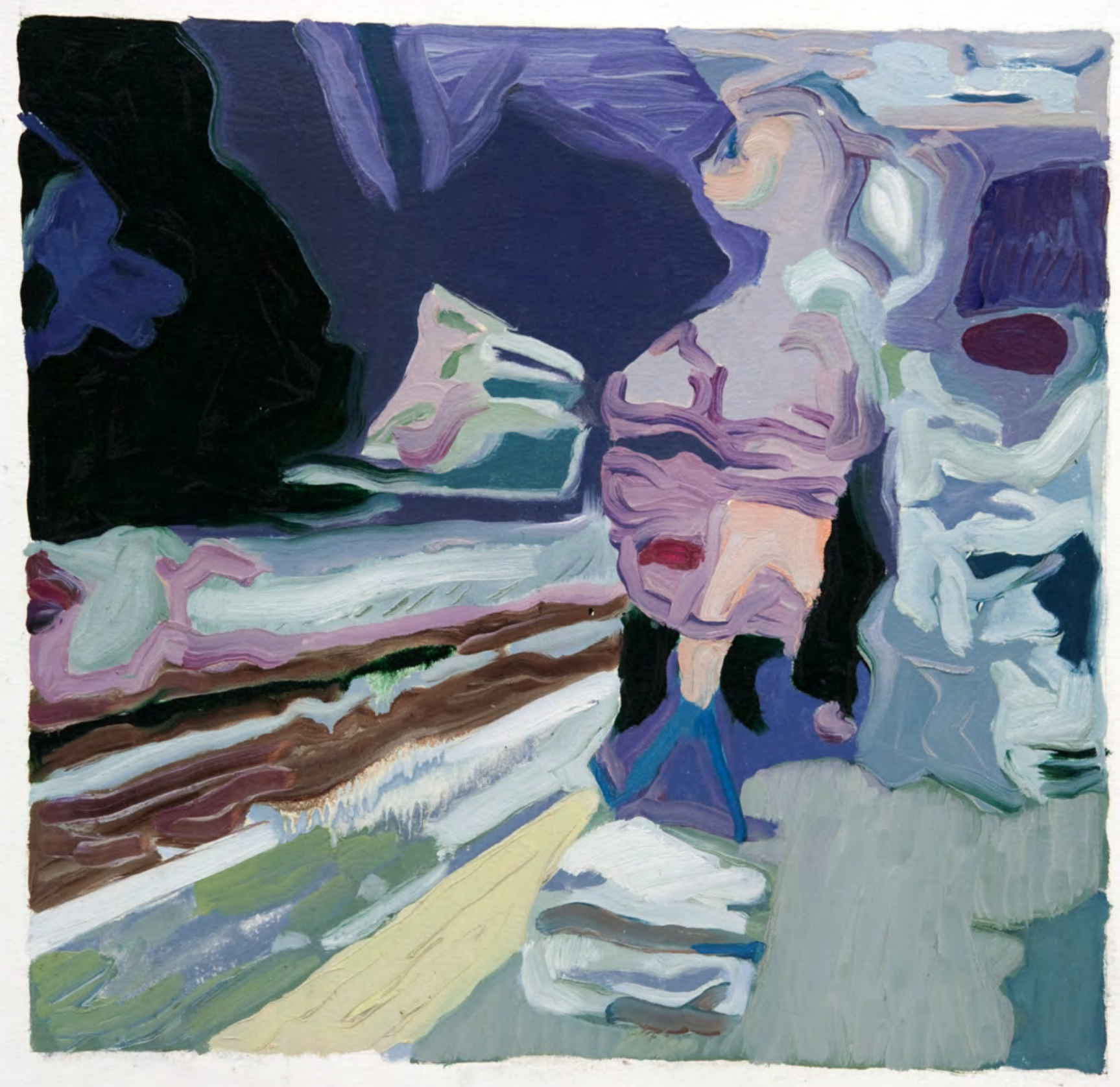

Plataforma, 2011, óleo sobre tela, 60 x 62 cm 


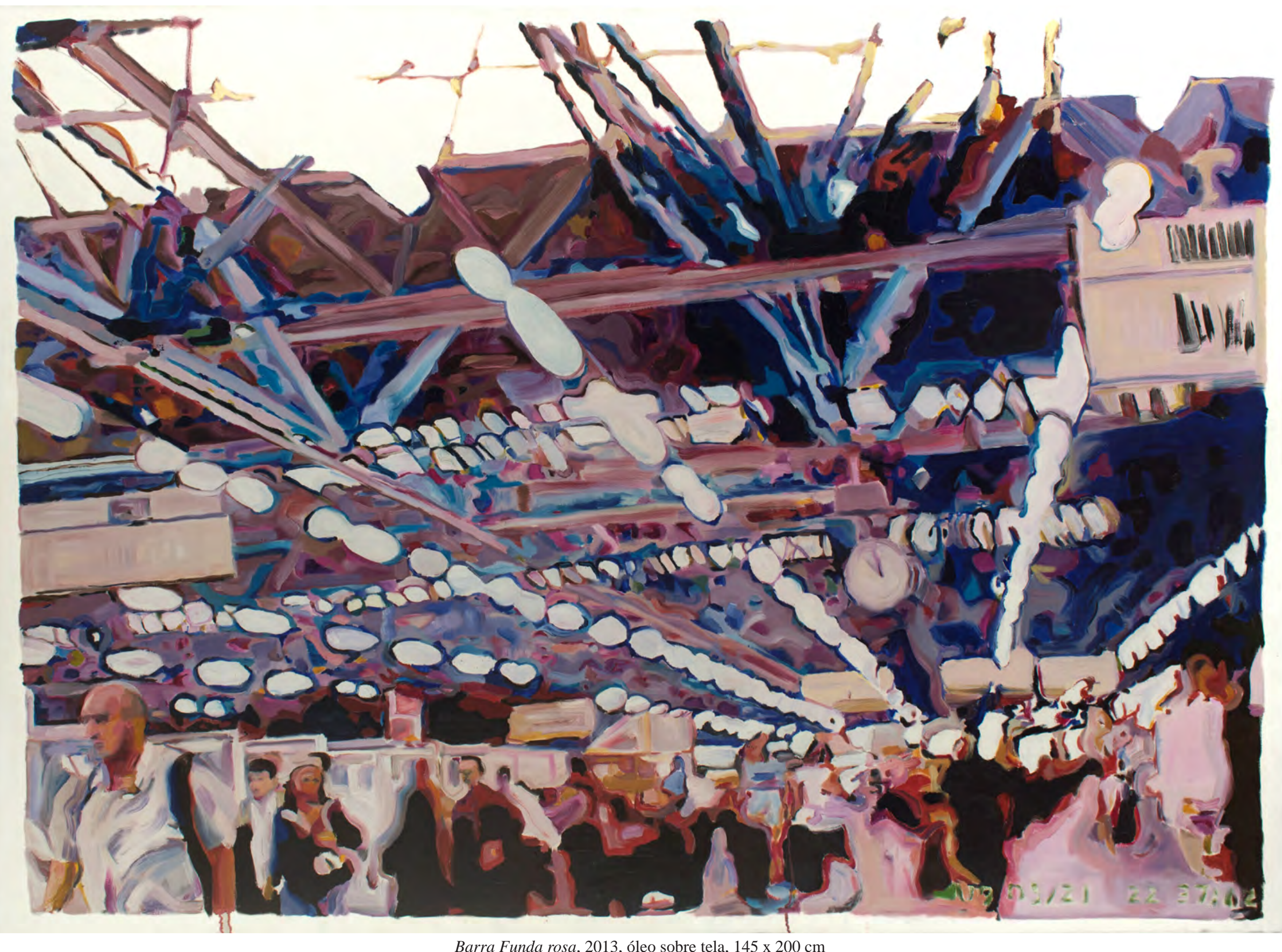




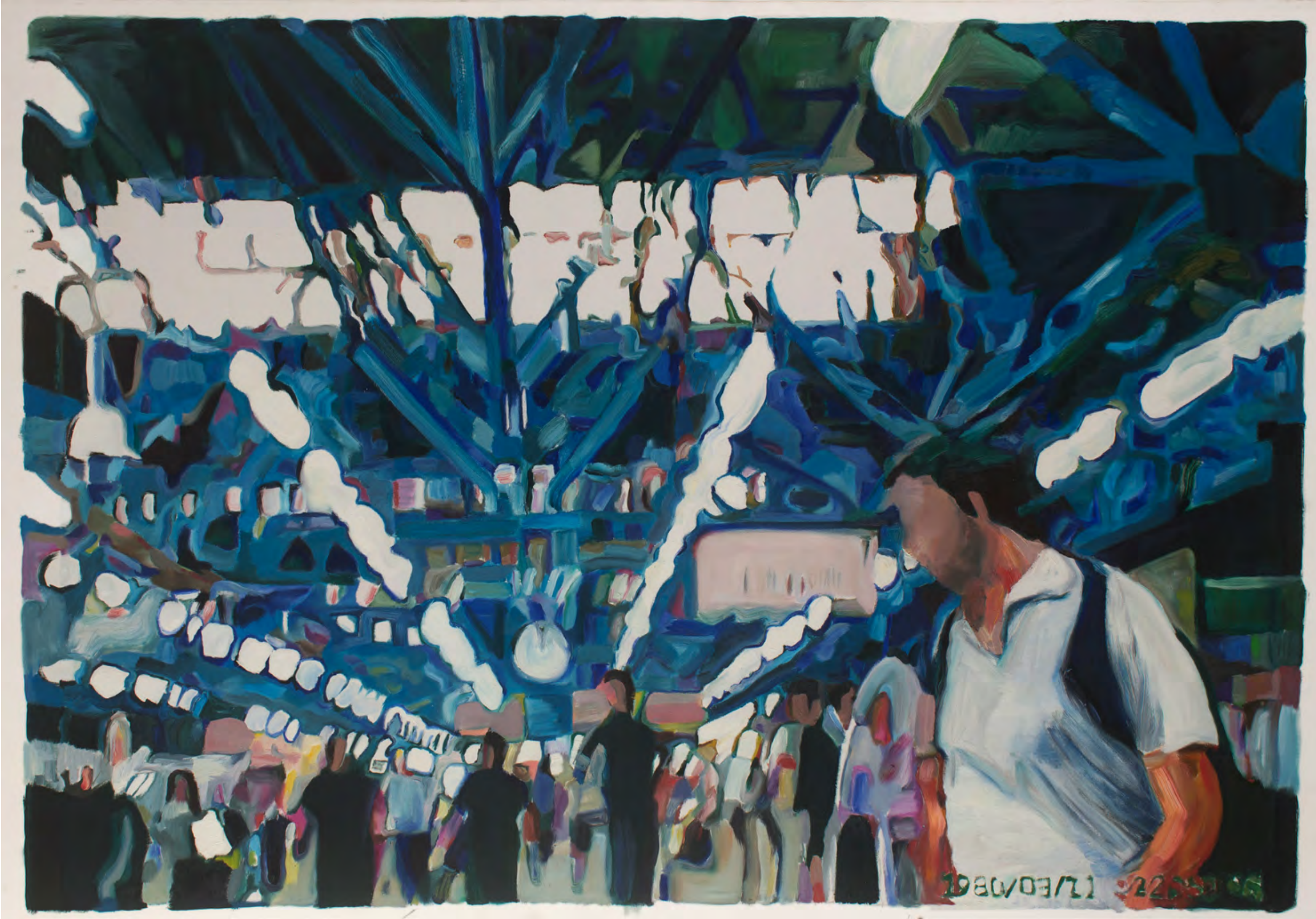




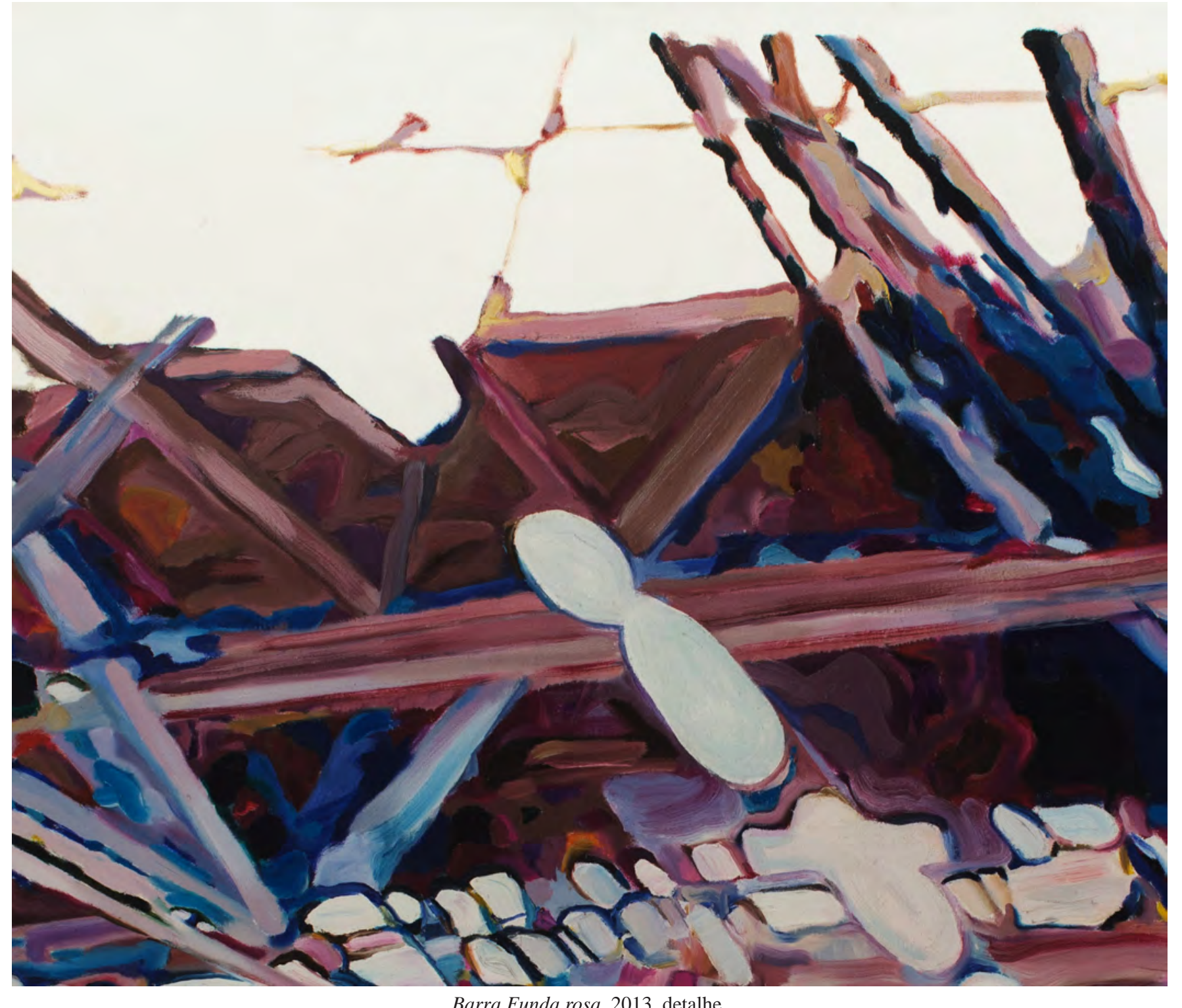




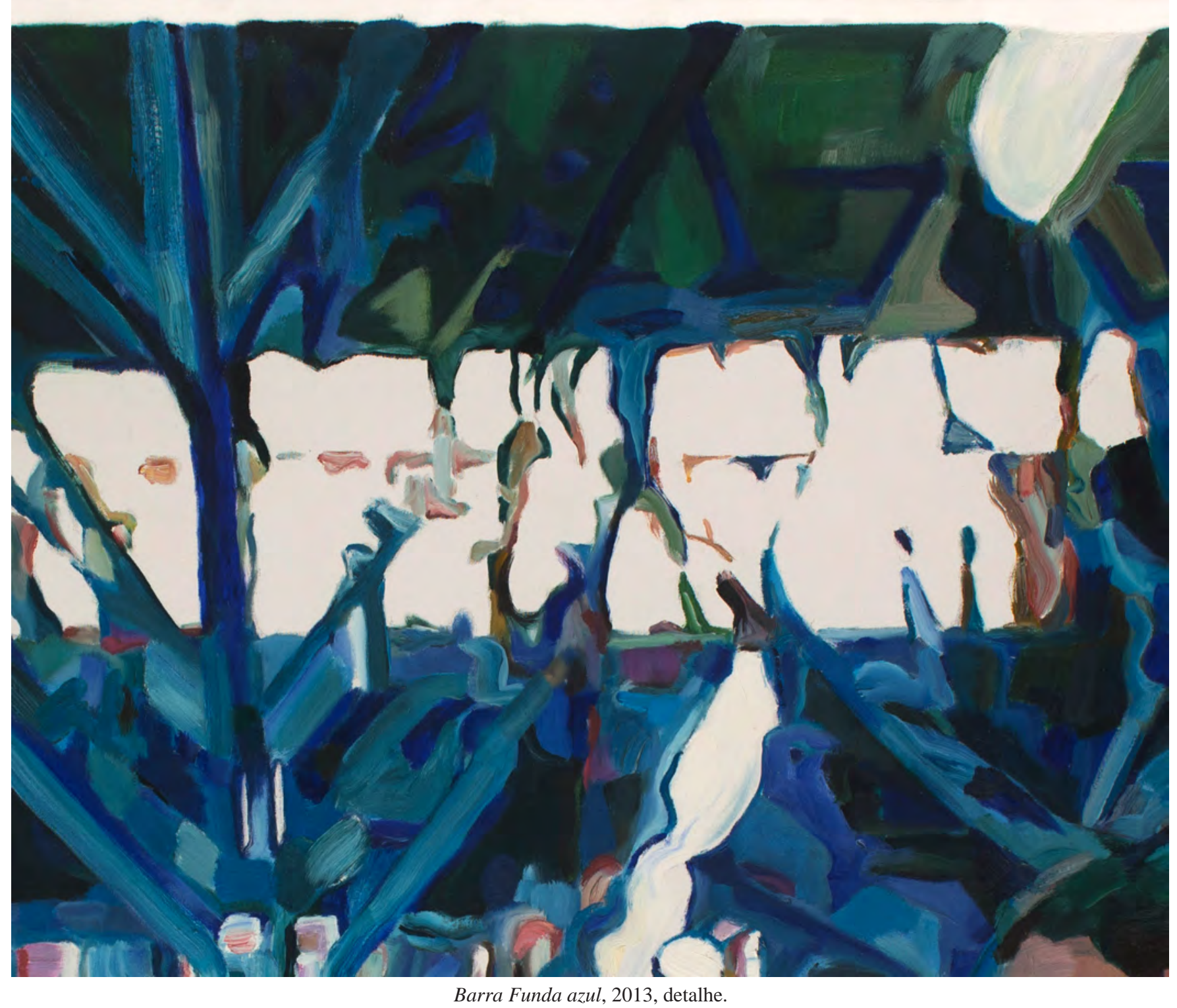




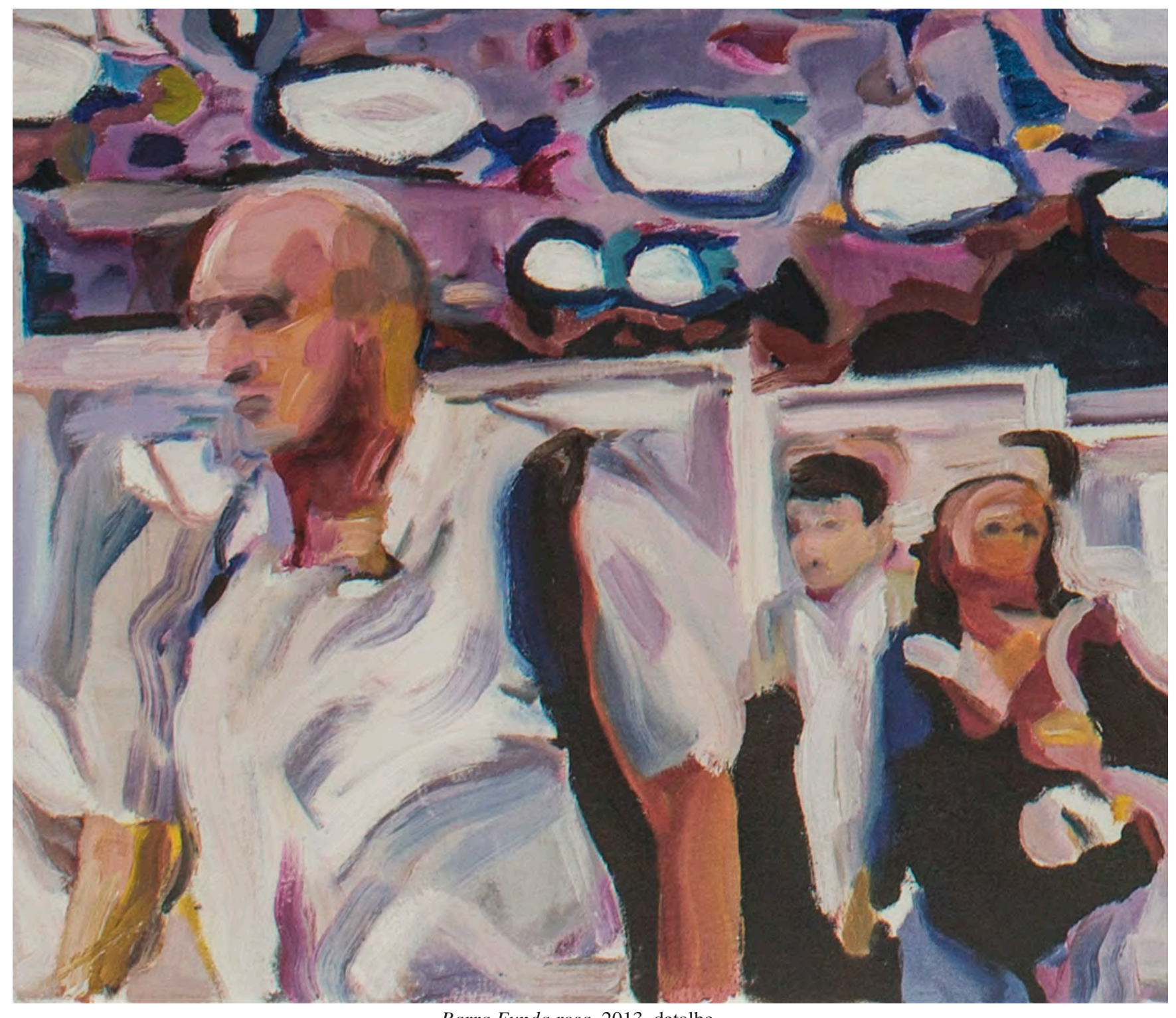

Barra Funda rosa, 2013, detalhe.

$\oplus$ 


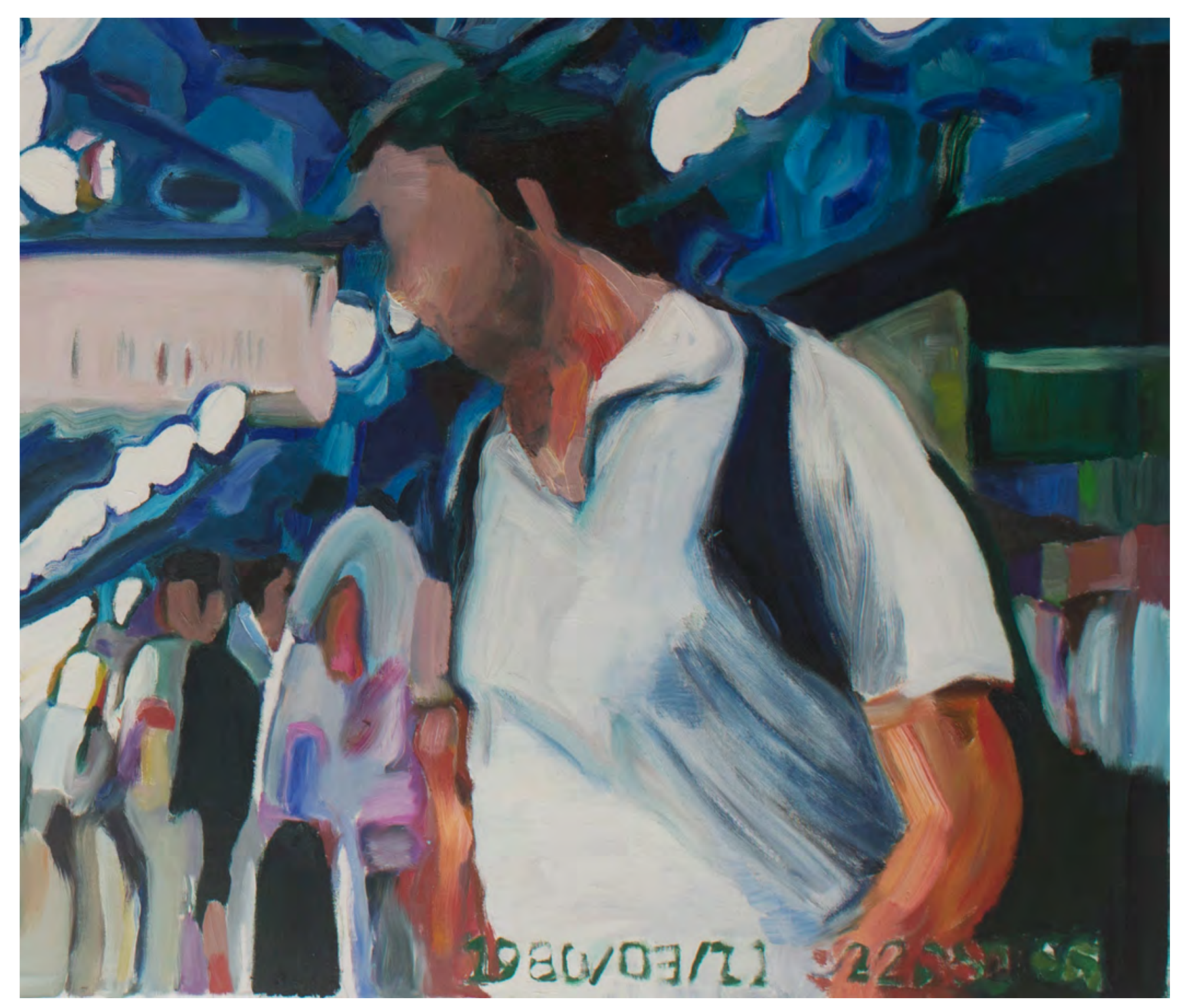

Barra Funda azul, 2013, detalhe. 


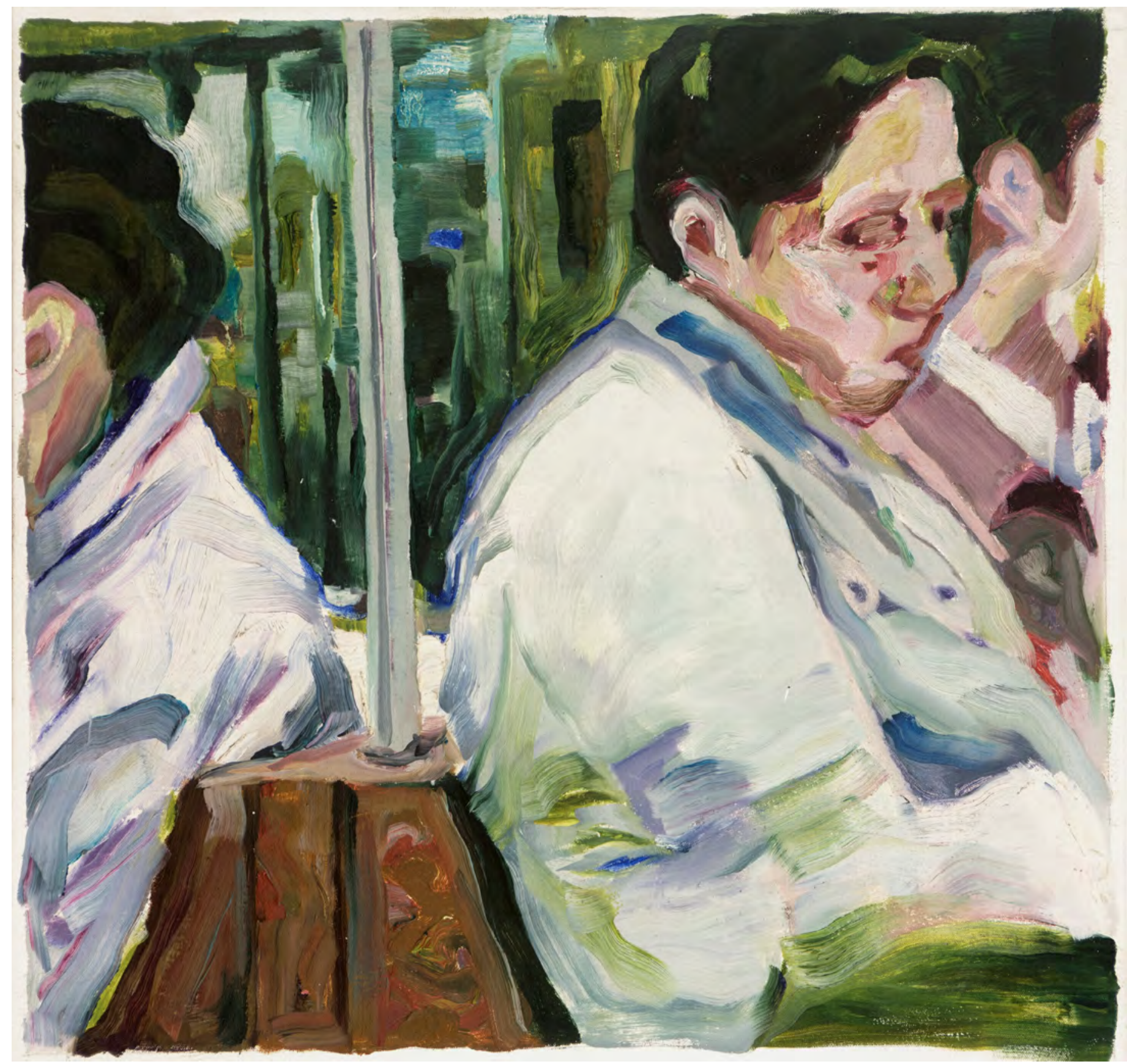

Três, 2011, óleo sobre tela, 66 x 70 cm 


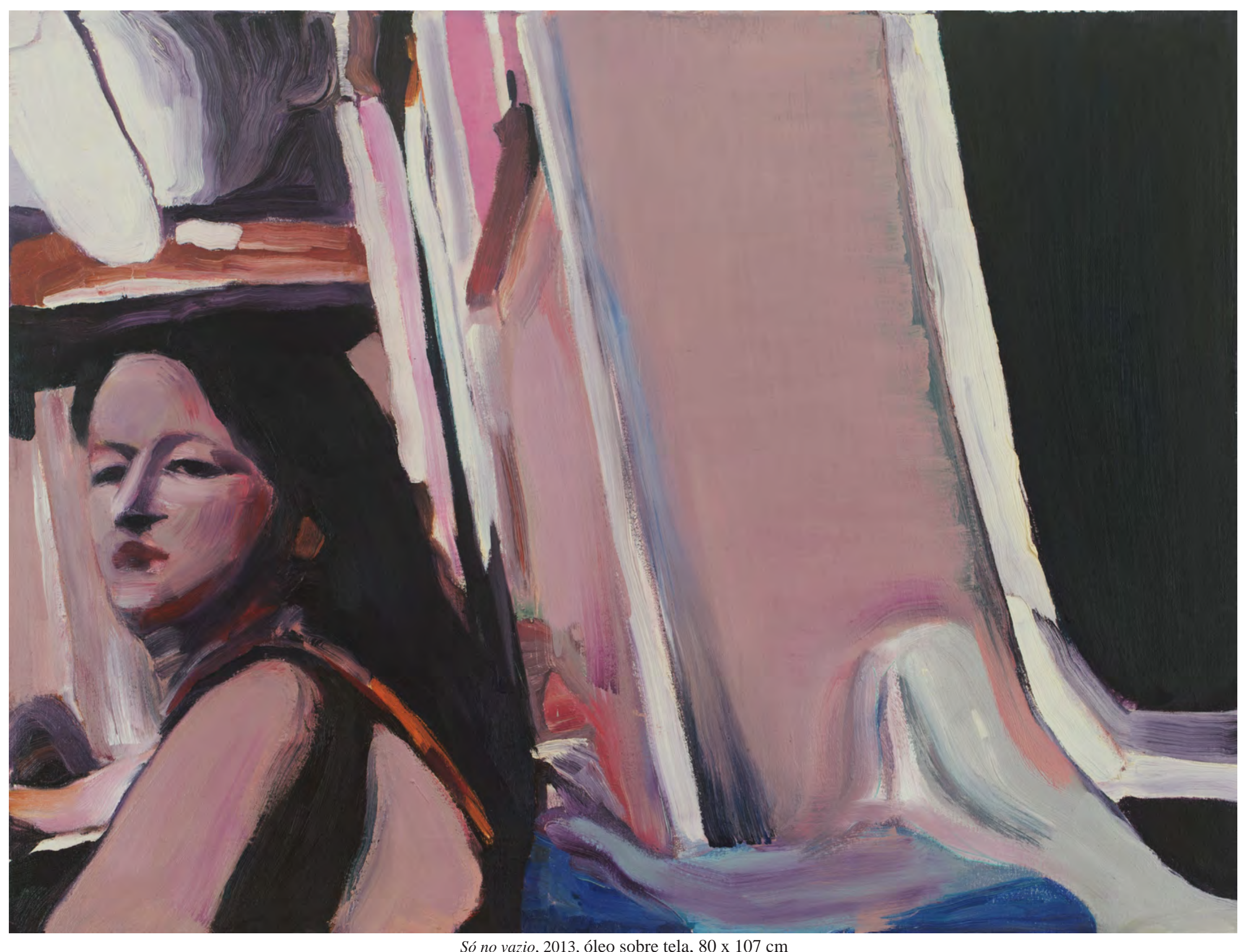

$\oplus$

$(\theta)$ 


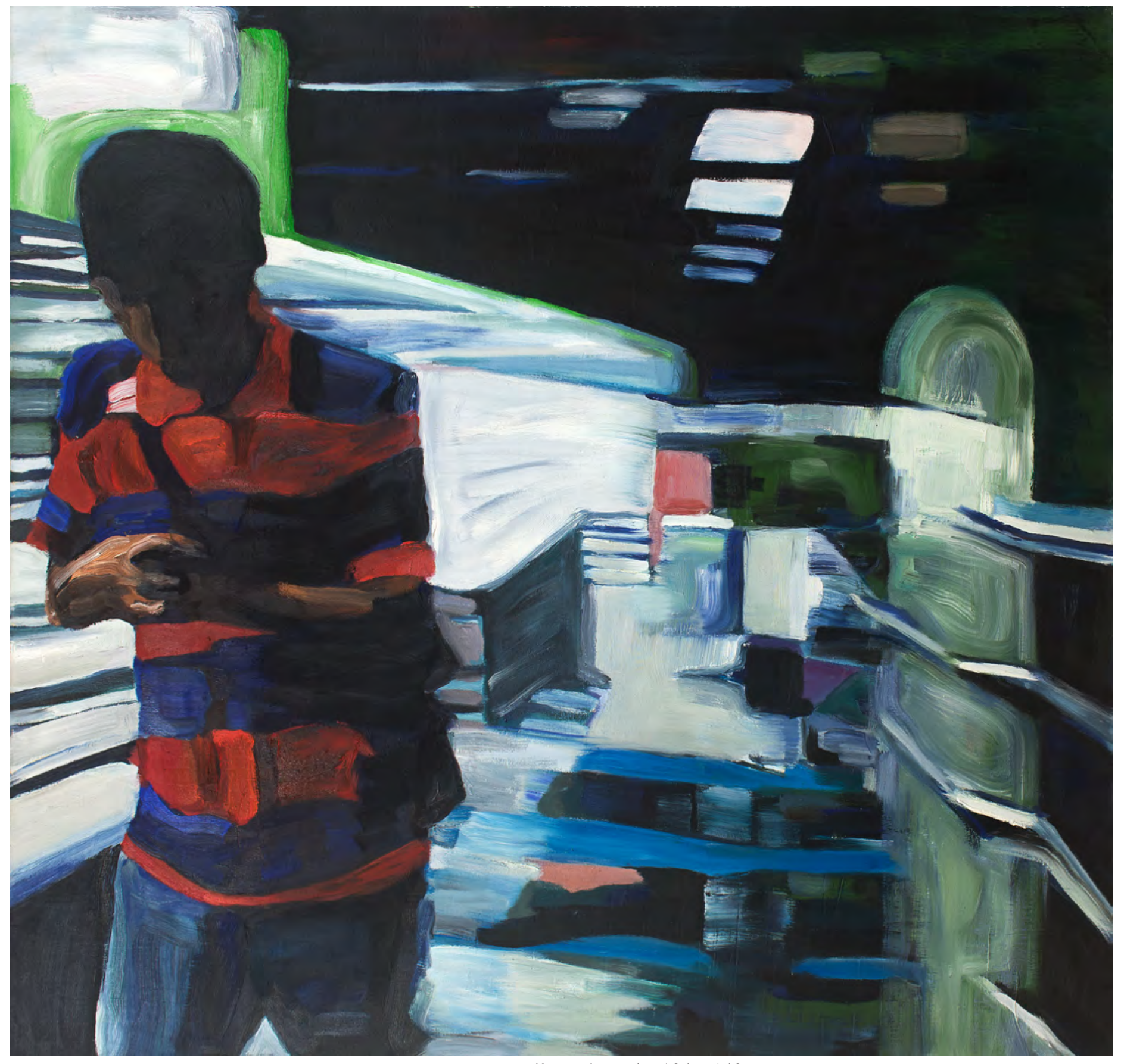

Camisa Listrada, 2013, óleo sobre tela, 134 x 140 cm 


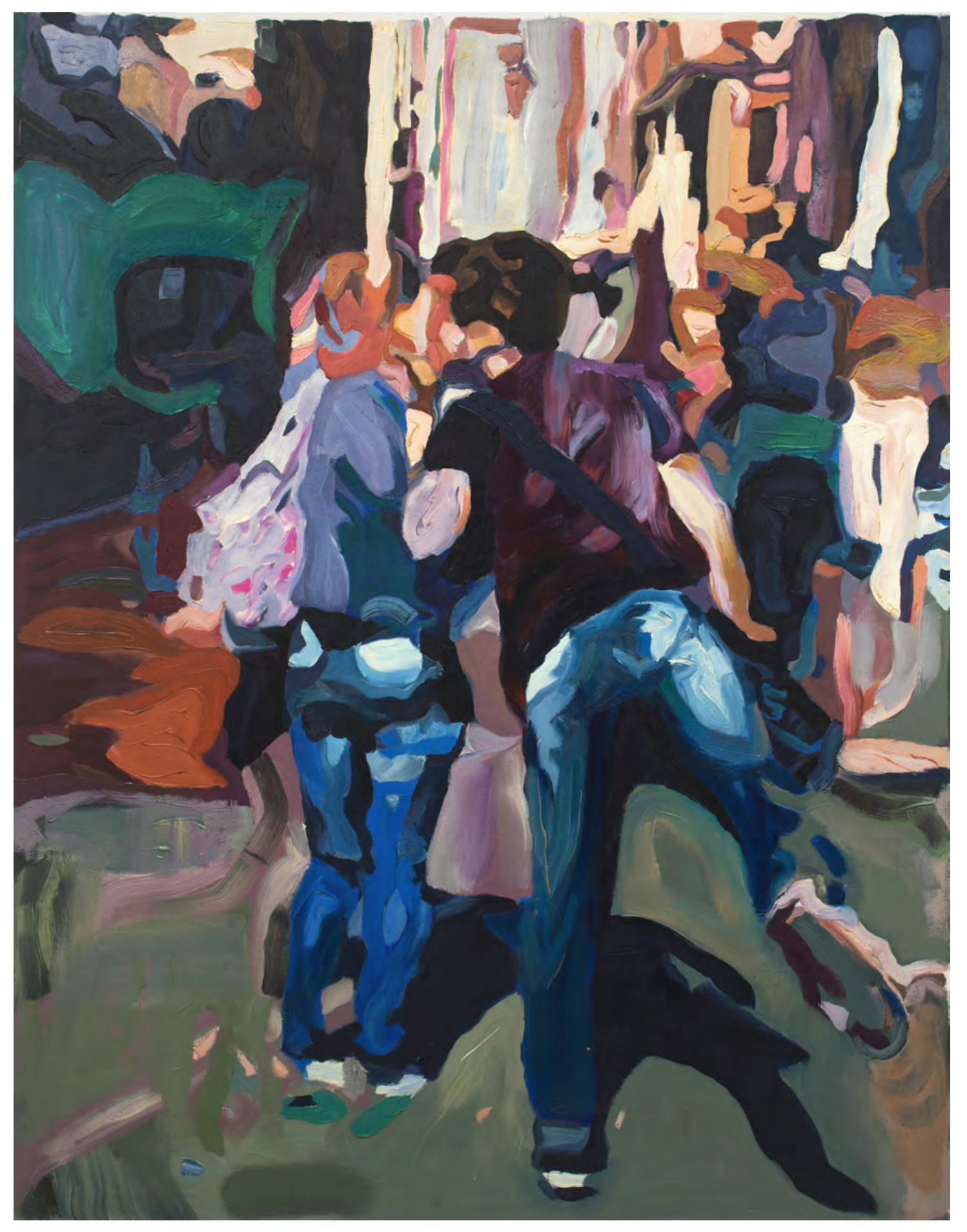

$\theta$ 



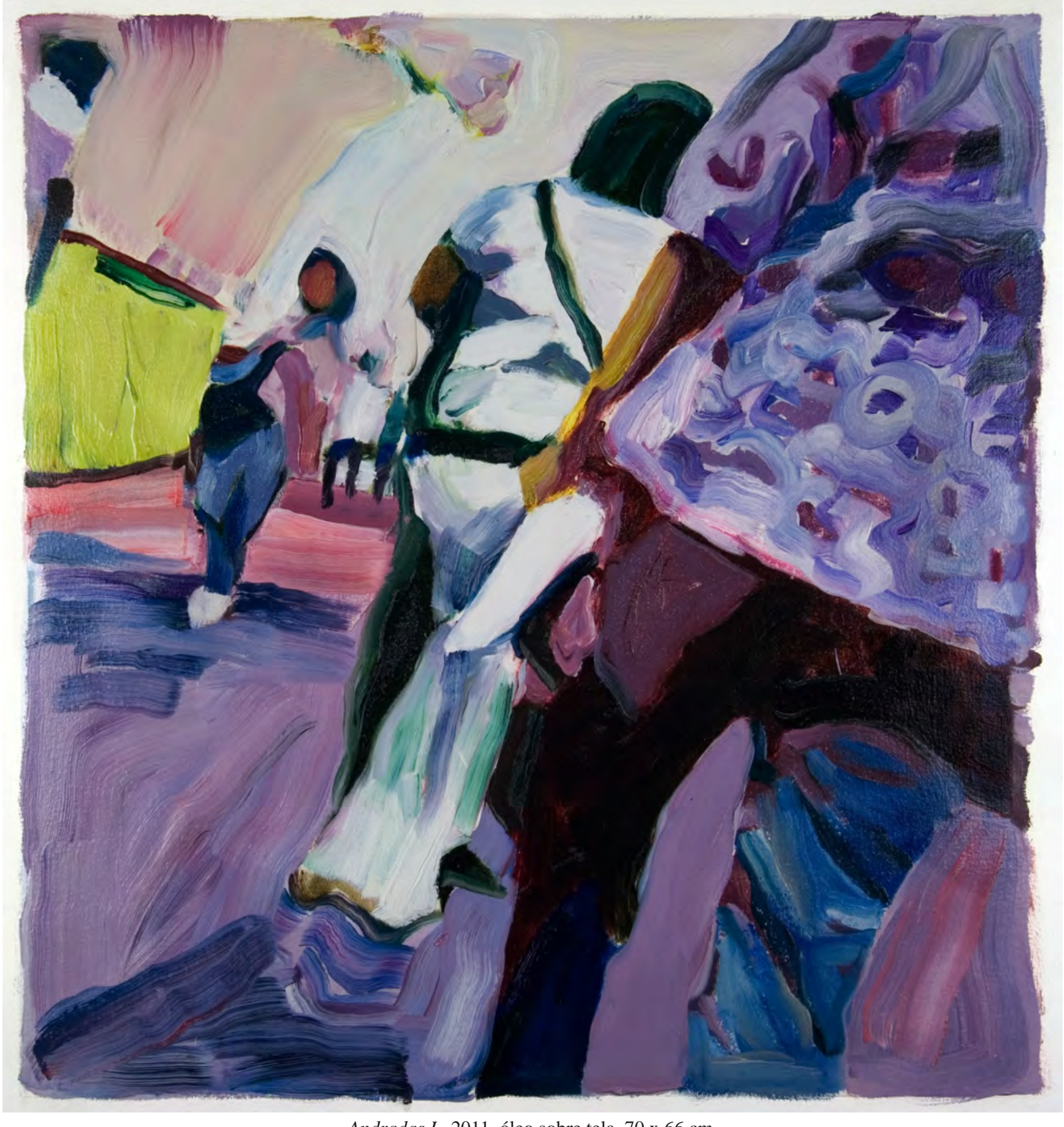

Andradas I, 2011, óleo sobre tela, 70 x 66 cm

$\oplus$ 


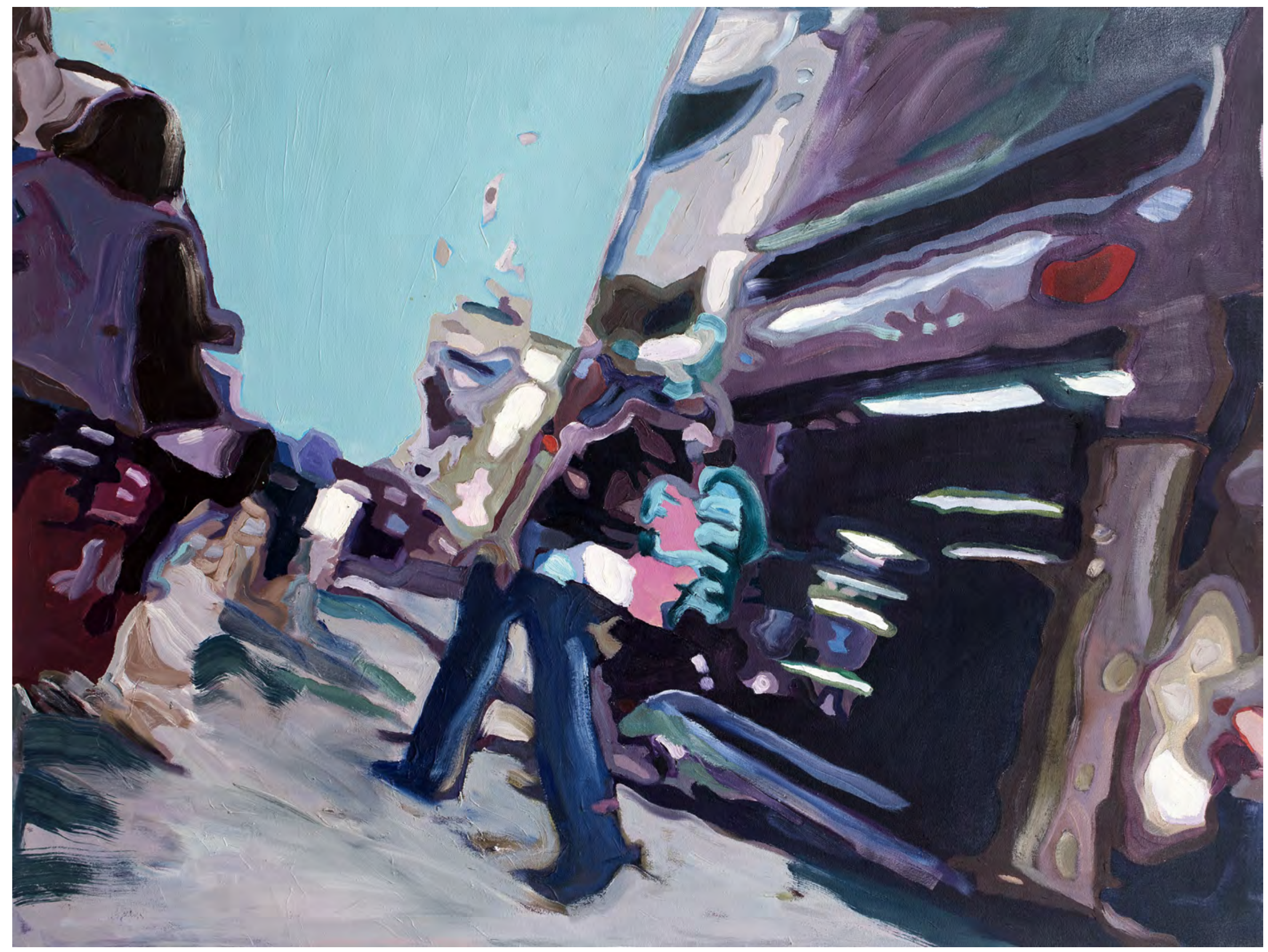

De passagem, 2013, óleo sobre tela, 115 x 150 cm 


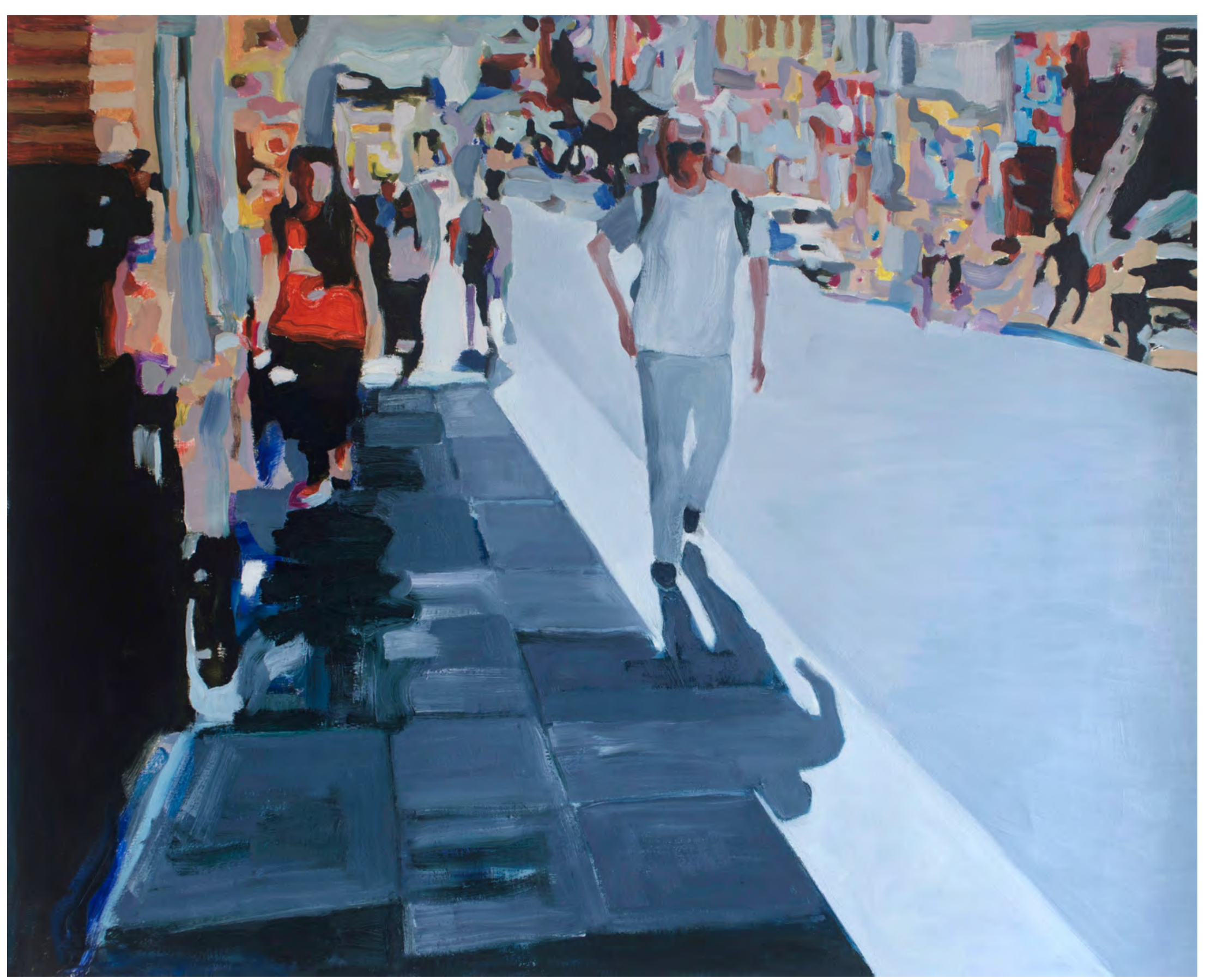

Contra luz na Andradas, 2013, óleo sobre tela, 115 x 105 cm 


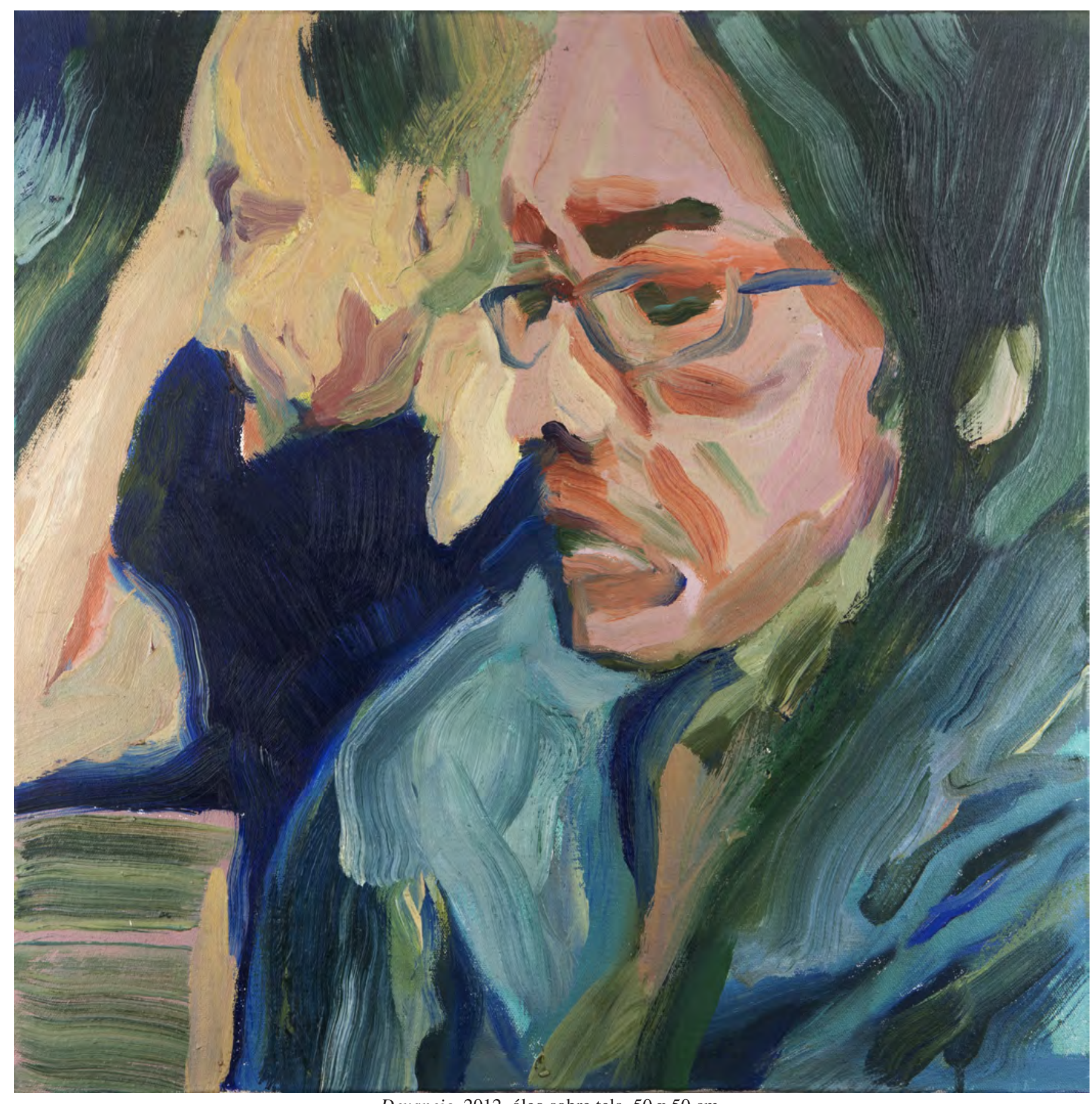

Devaneio, 2012, óleo sobre tela, 50 x $50 \mathrm{~cm}$ 


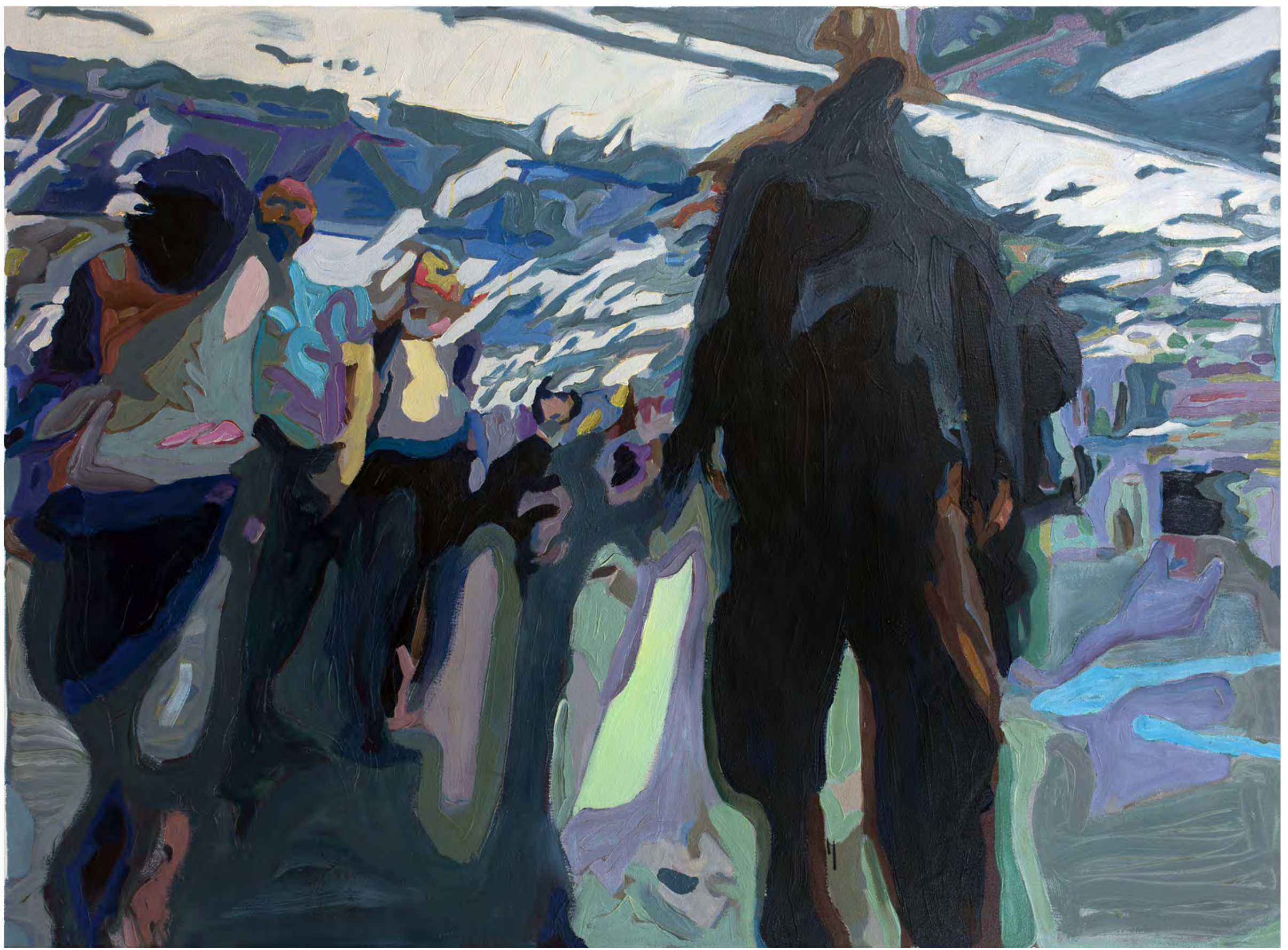

Sombra , 2012, óleo sobre tela, 115 x $142 \mathrm{~cm}$ 


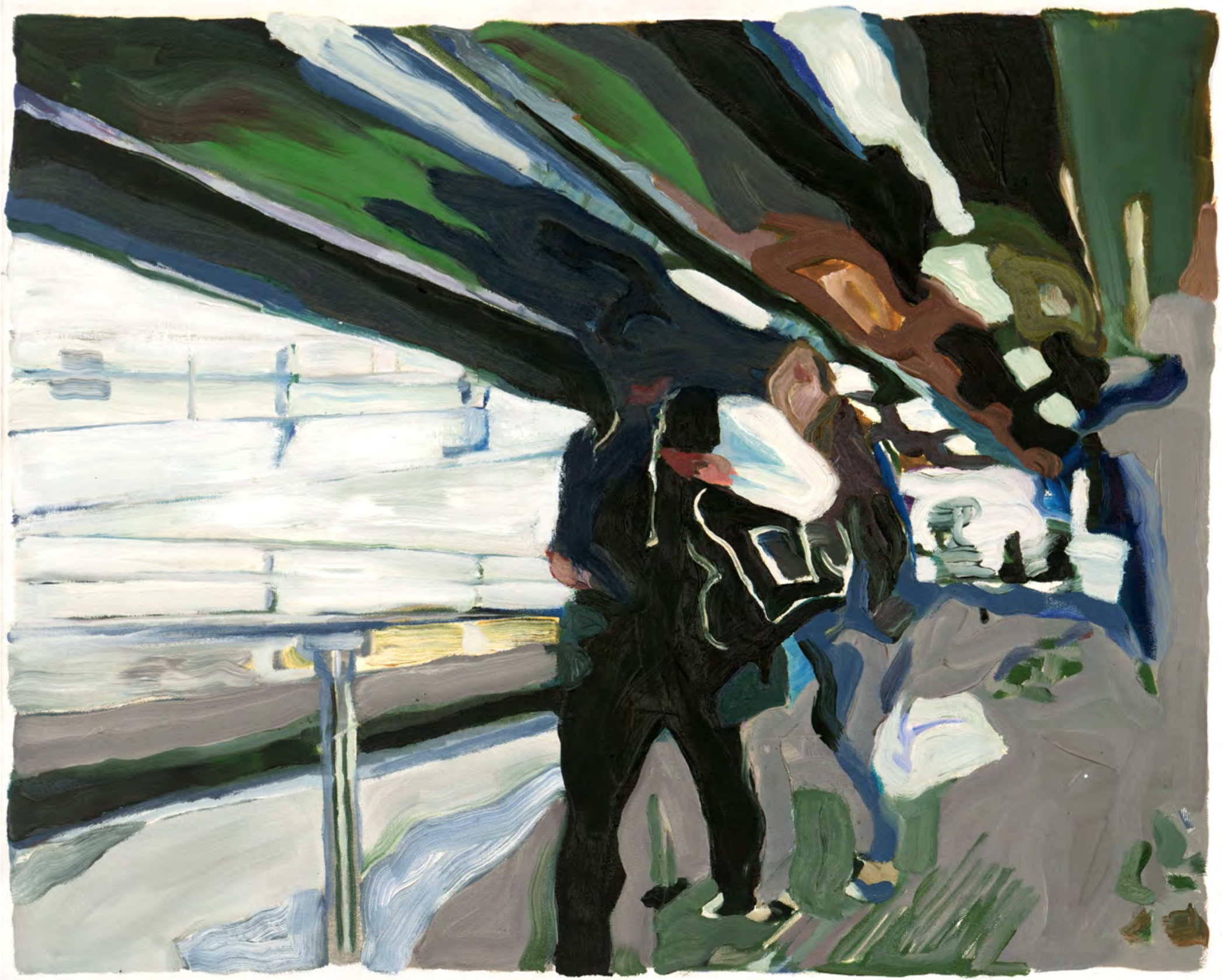

Ponto de fuga, 2011, óleo sobre tela, 56 x 66 cm 


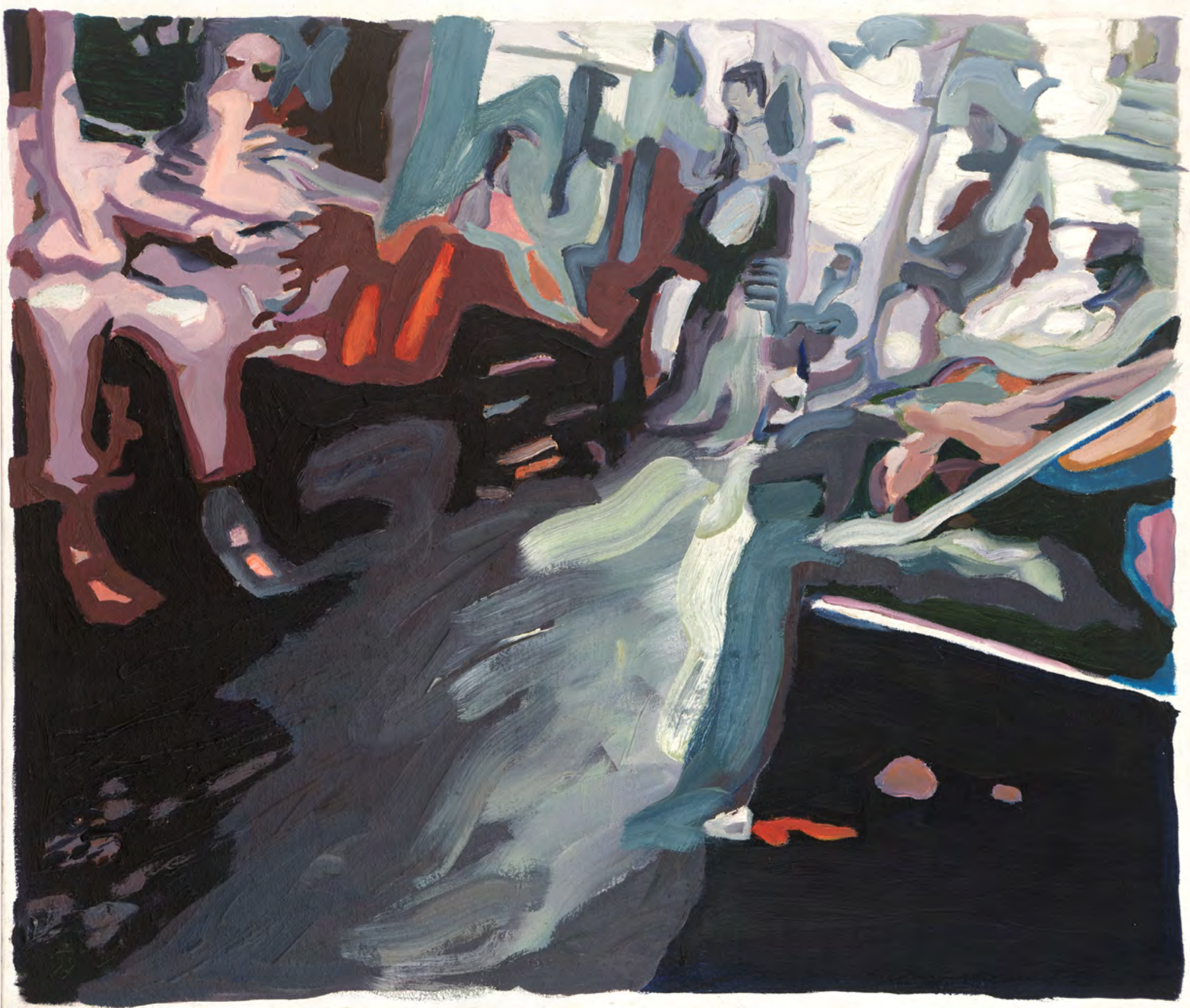

Vagão, 2011, óleo sobre tela, 70 x 82 cm 


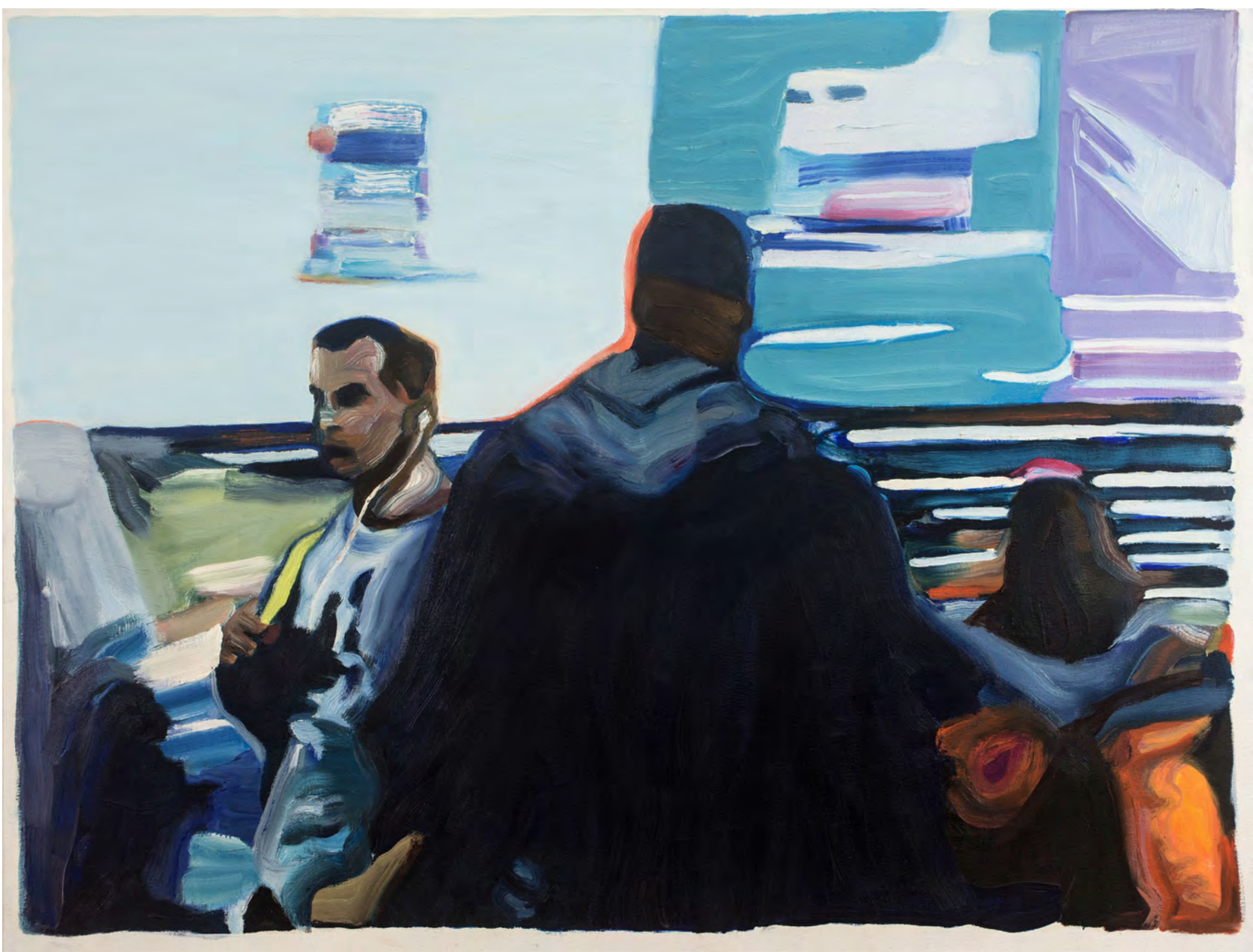

Fone de Ouvido, 2013, óleo sobre tela, 100 x $130 \mathrm{~cm}$ 


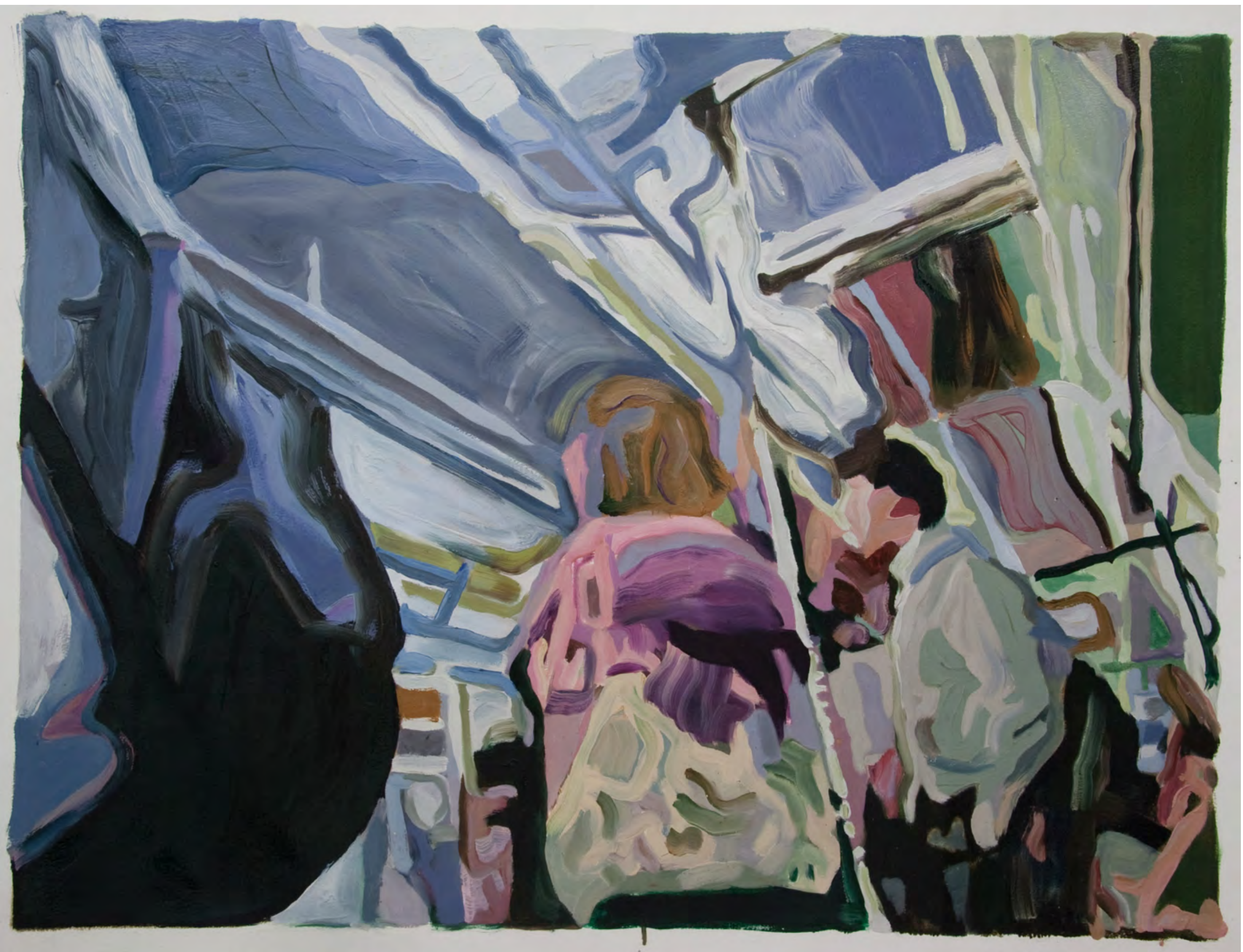

Metrô II, 2011, óleo sobre tela, 110 x 143 cm 


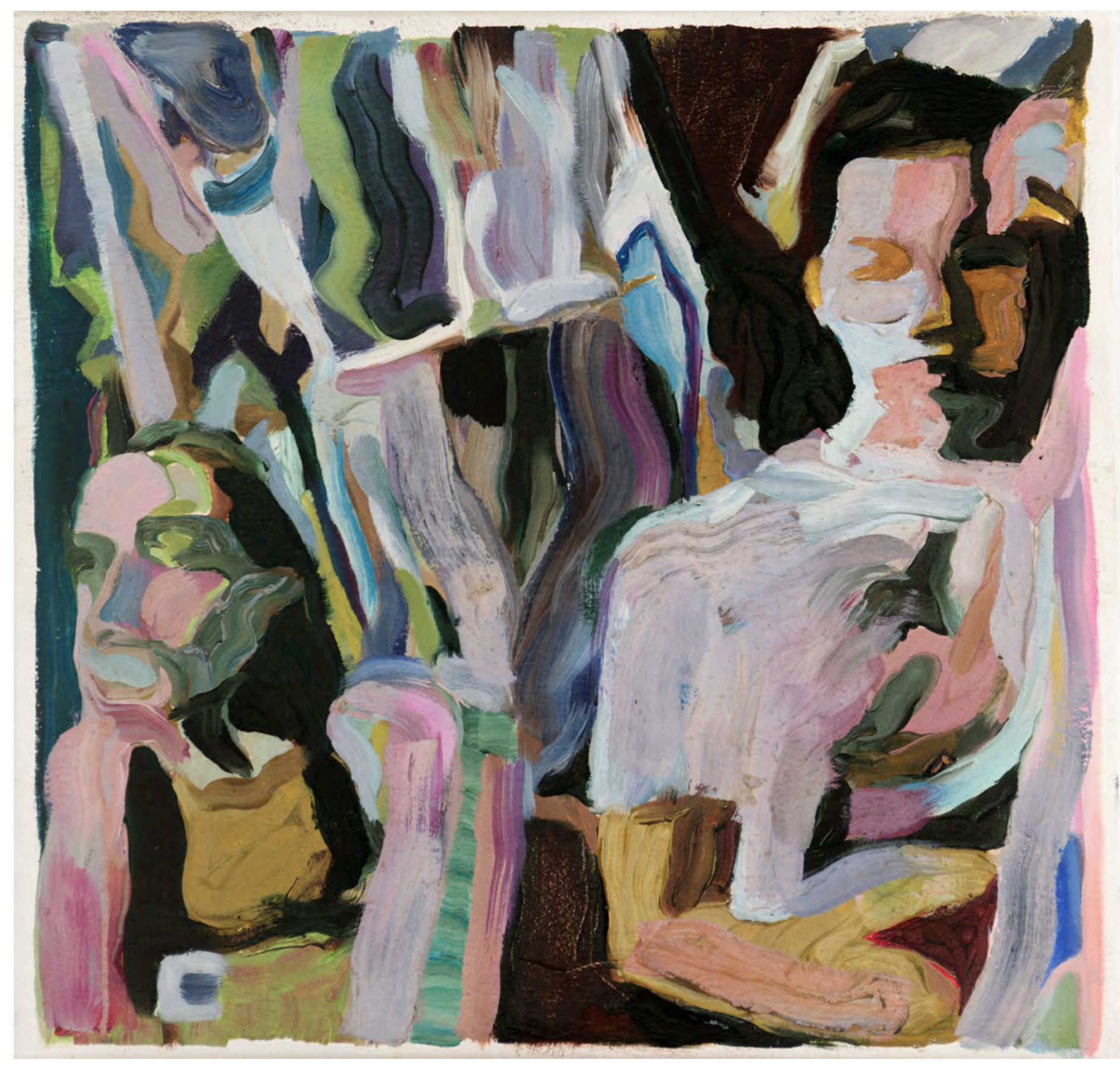

Viajando, 2011, óleo sobre tela, 59 x 63 cm 


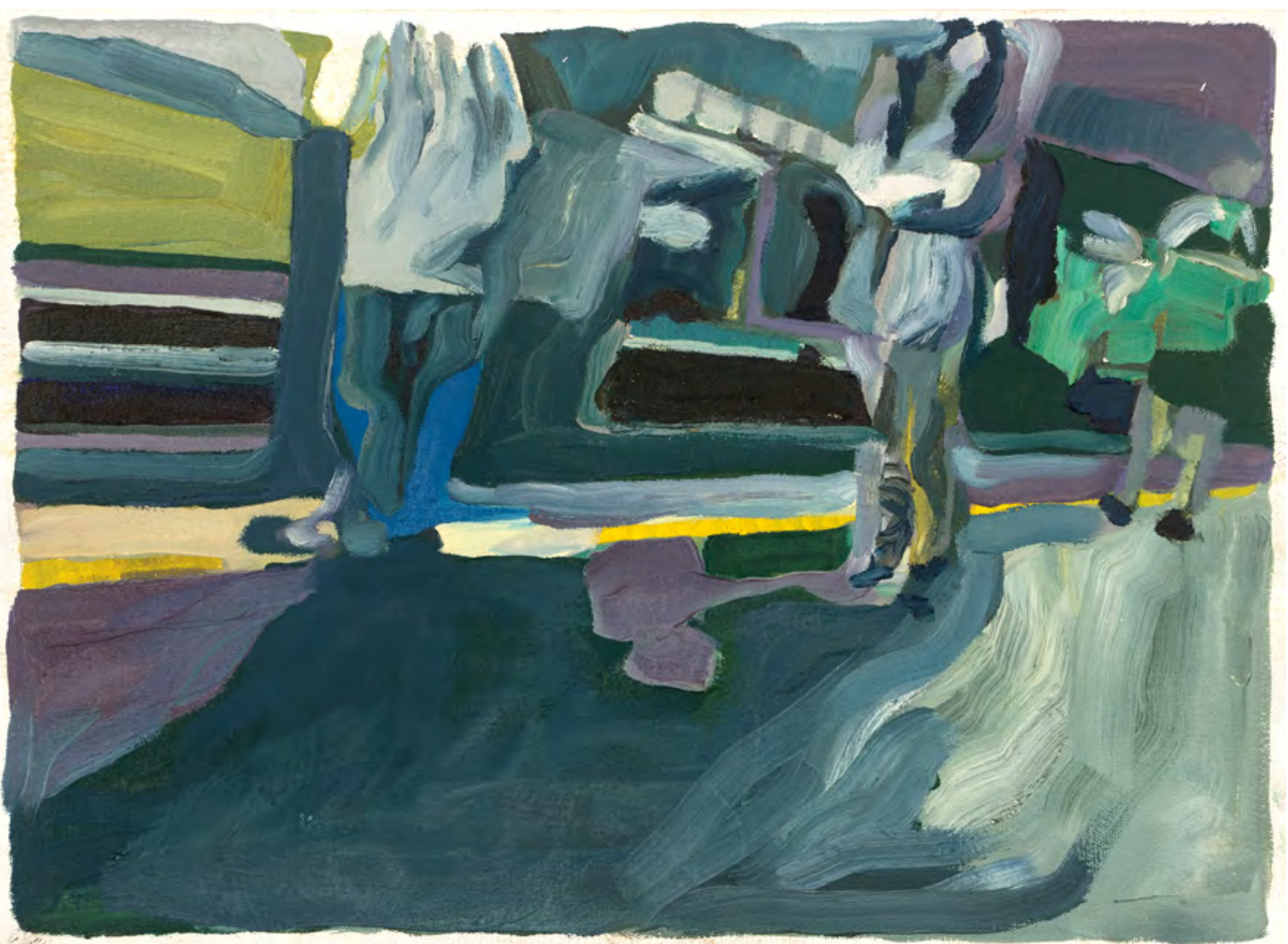

Plataforma II, 2011, óleo sobre tela, 37,5 x 50 cm 


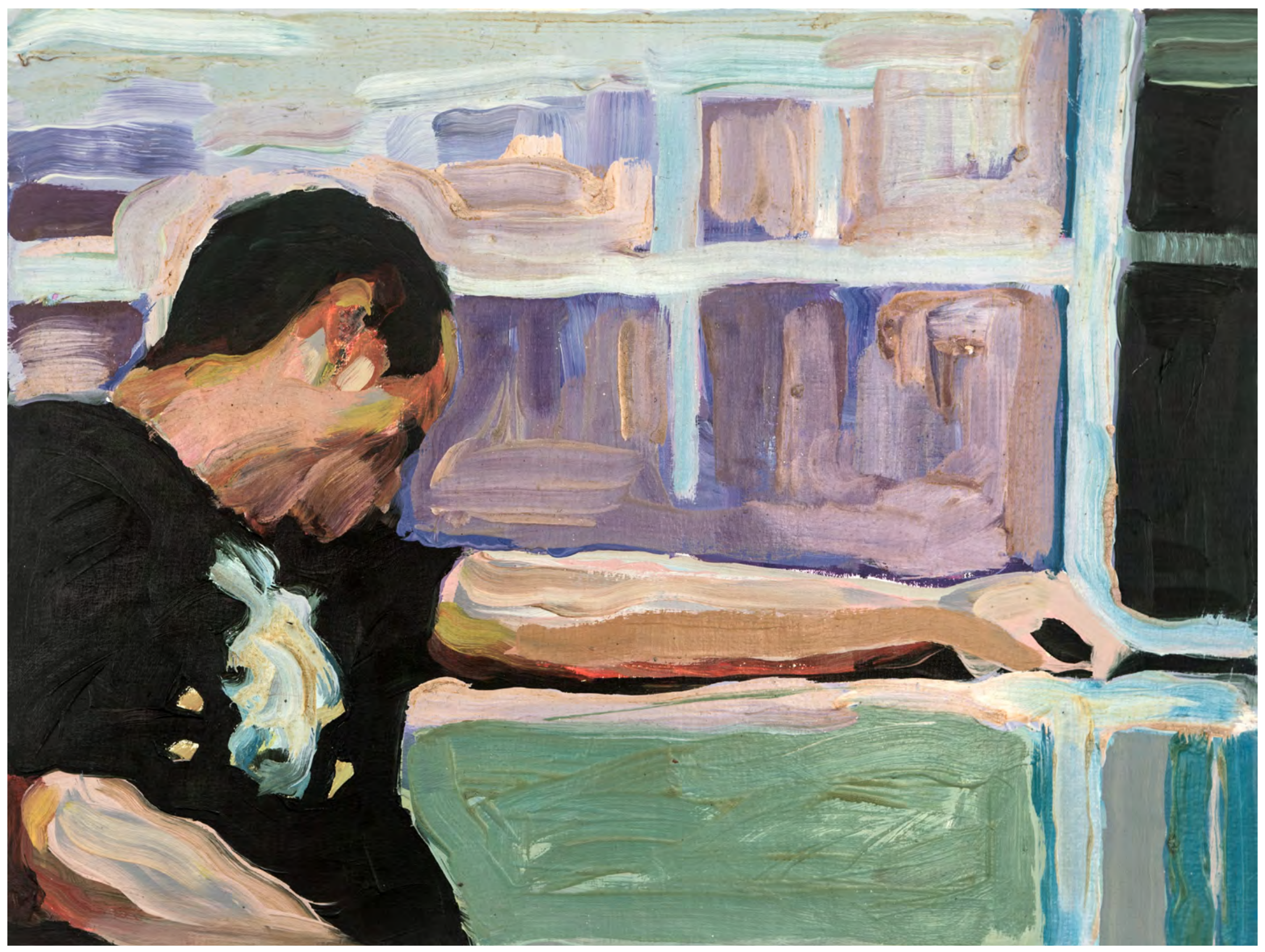

Absorto, 2011, óleo sobre tela, 48x $64 \mathrm{~cm}$ 


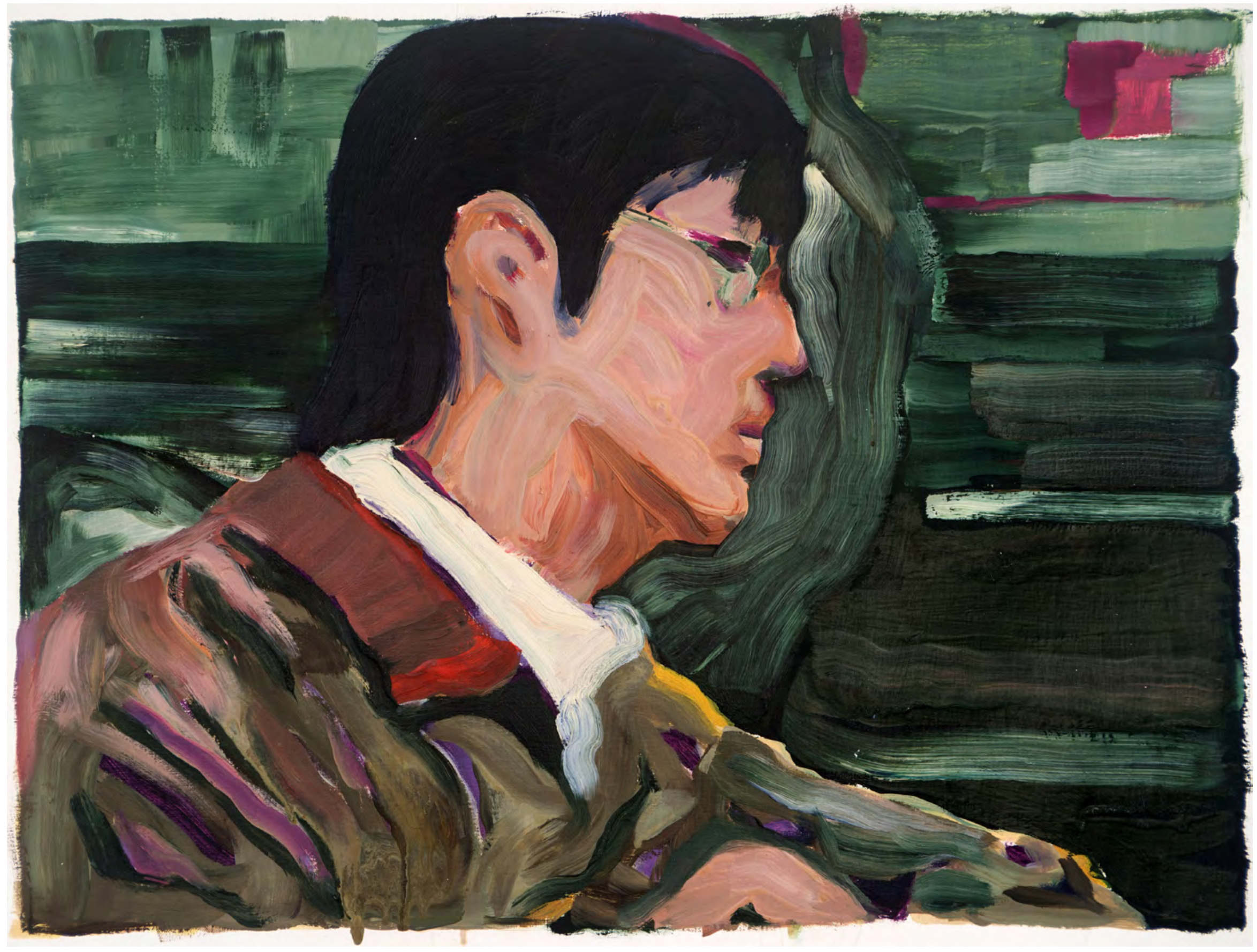

Japonês, 2011, óleo sobre tela, 49 x 66 cm 


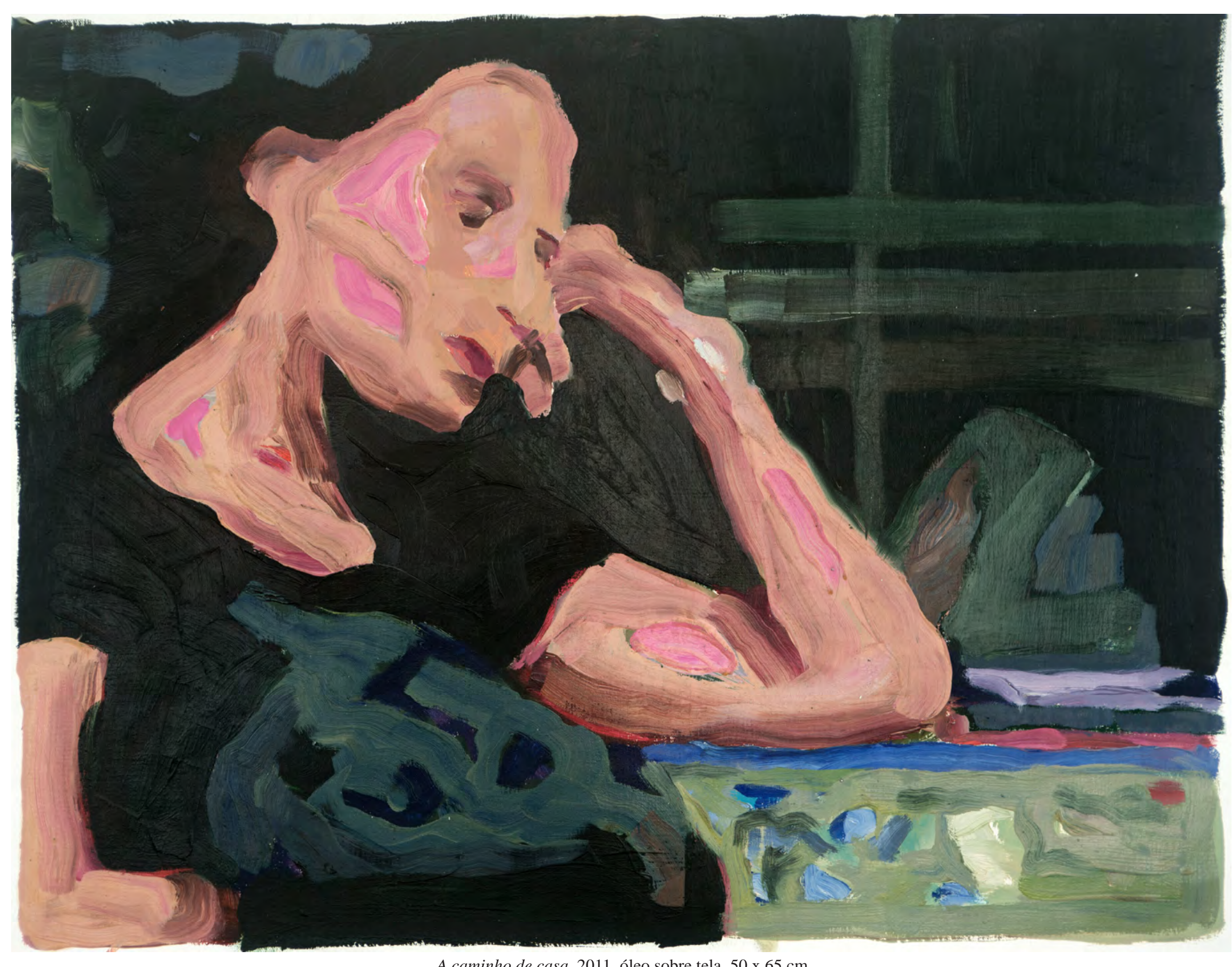

A caminho de casa, 2011, óleo sobre tela, 50 x 65 cm 


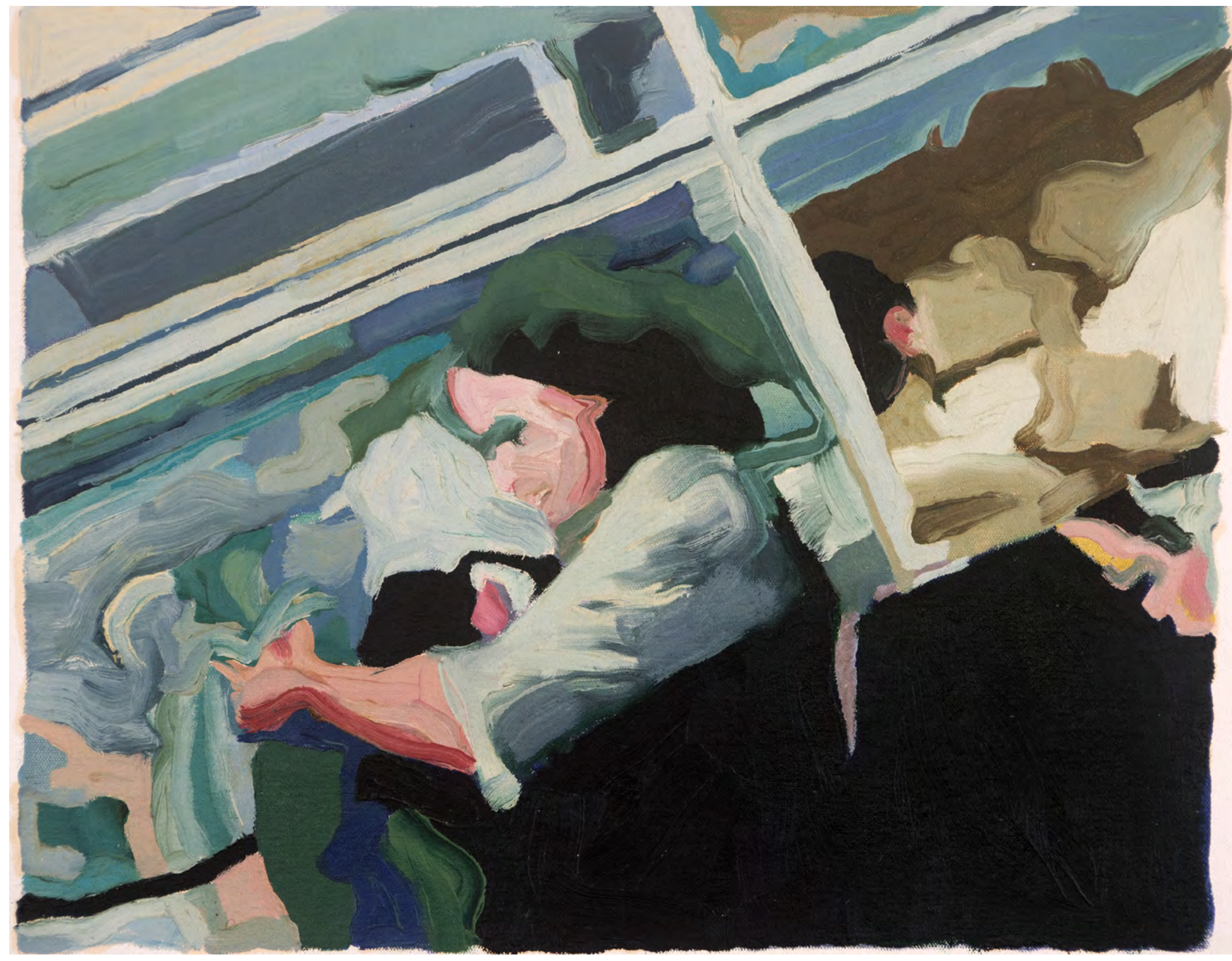

Moça em diagonal, 2011, óleo sobre tela, 40 x 50 cm 


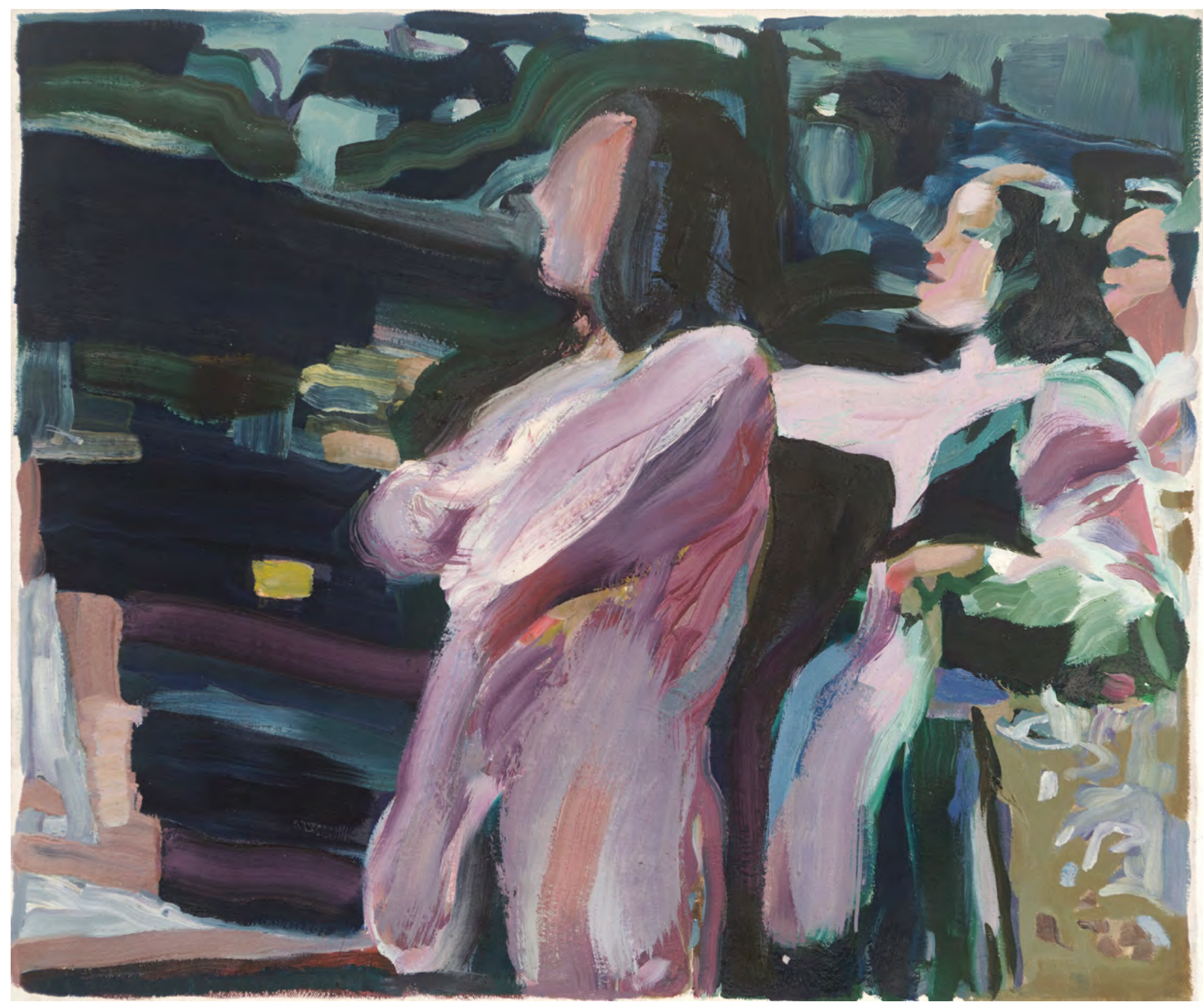

No ponto de ônibus, 2012, óleo sobre tela,54 x 65 cm 


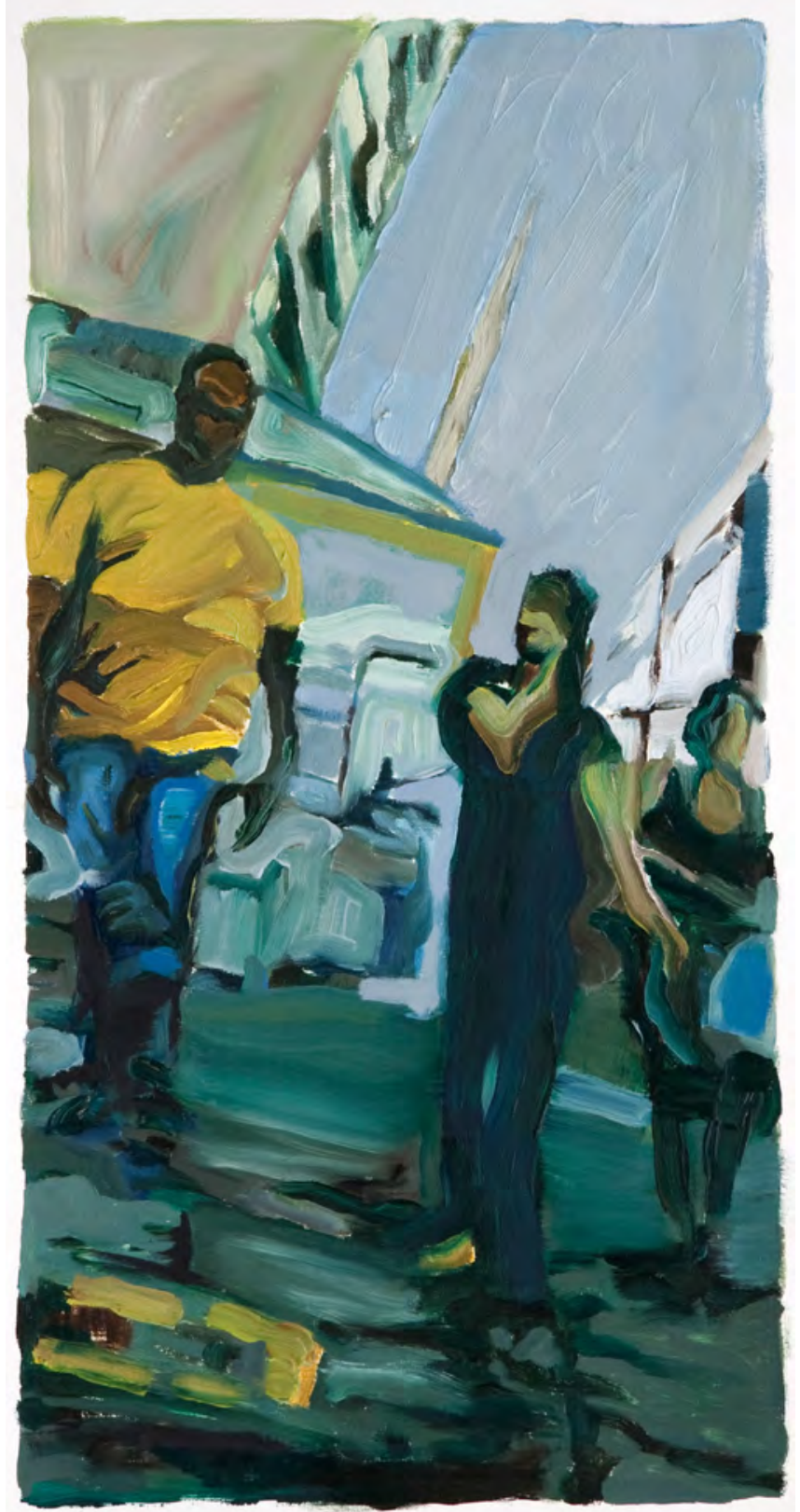

Camisa Amarela, 2011, óleo sobre tela, 67 x 35 cm

$\oplus$ 


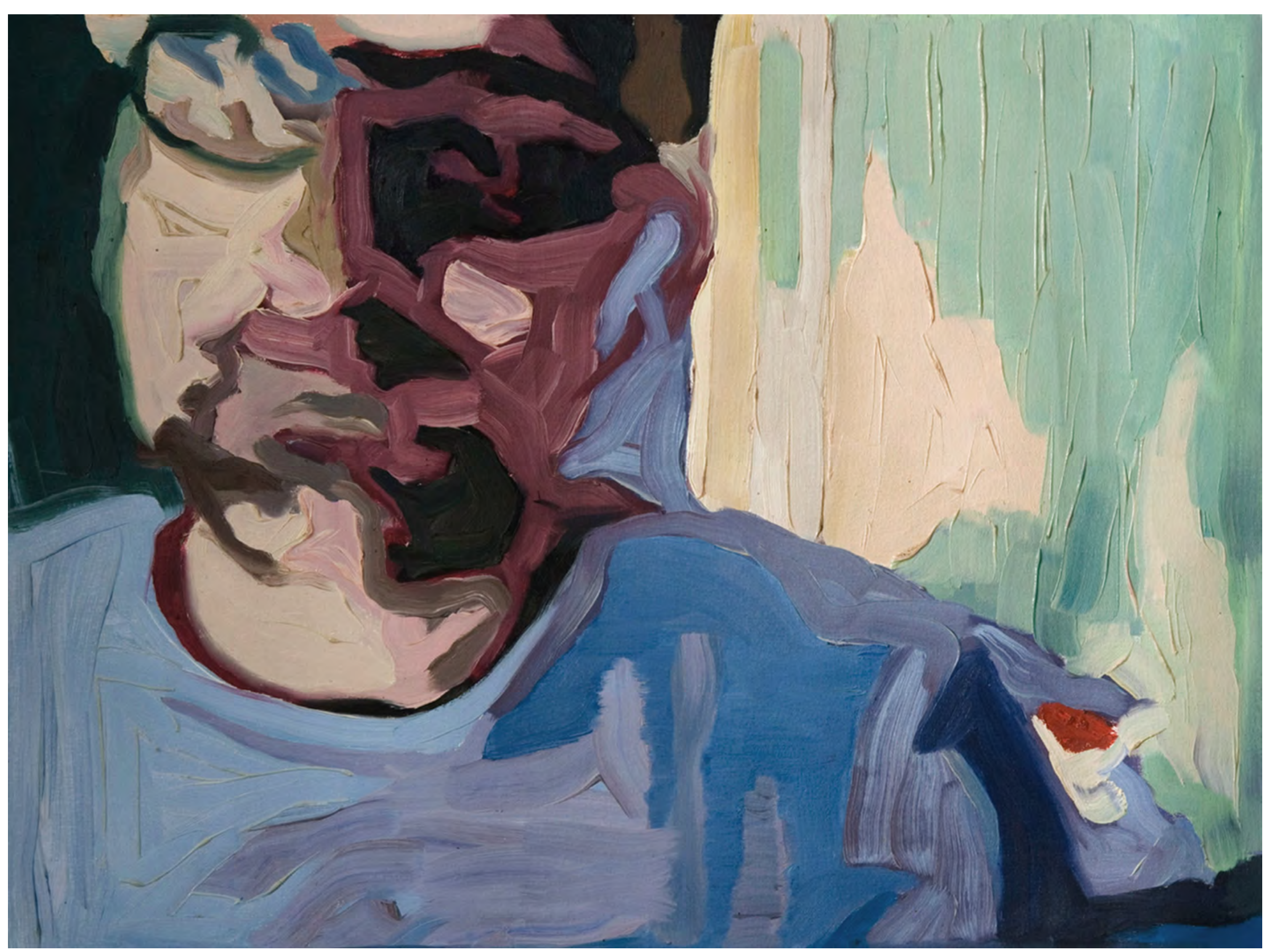

Gil em trânsito, 2010, óleo sobre tela, 61 x 80 cm 


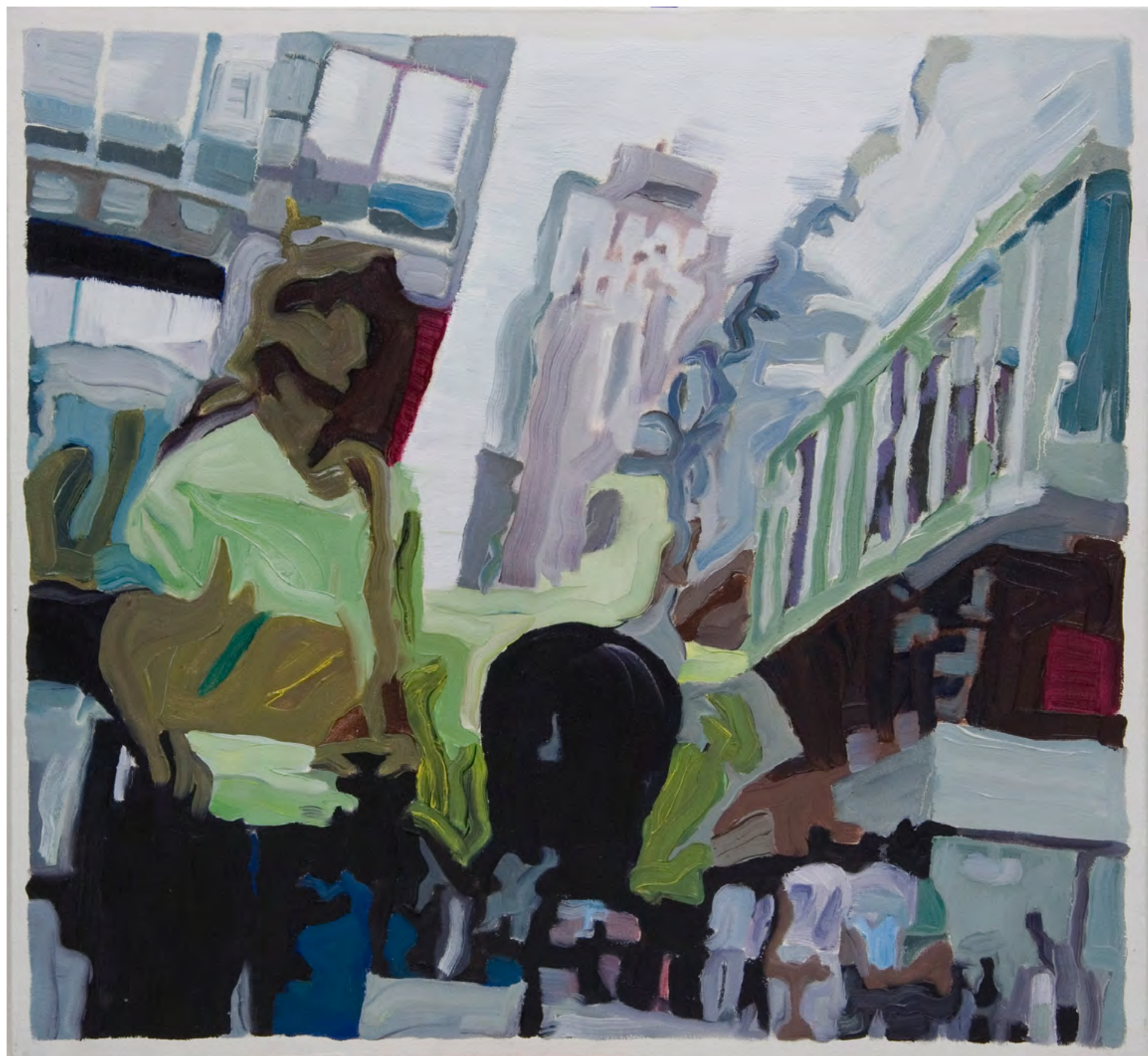

Orelhão, 2011, óleo sobre tela, 65 x 70 cm 


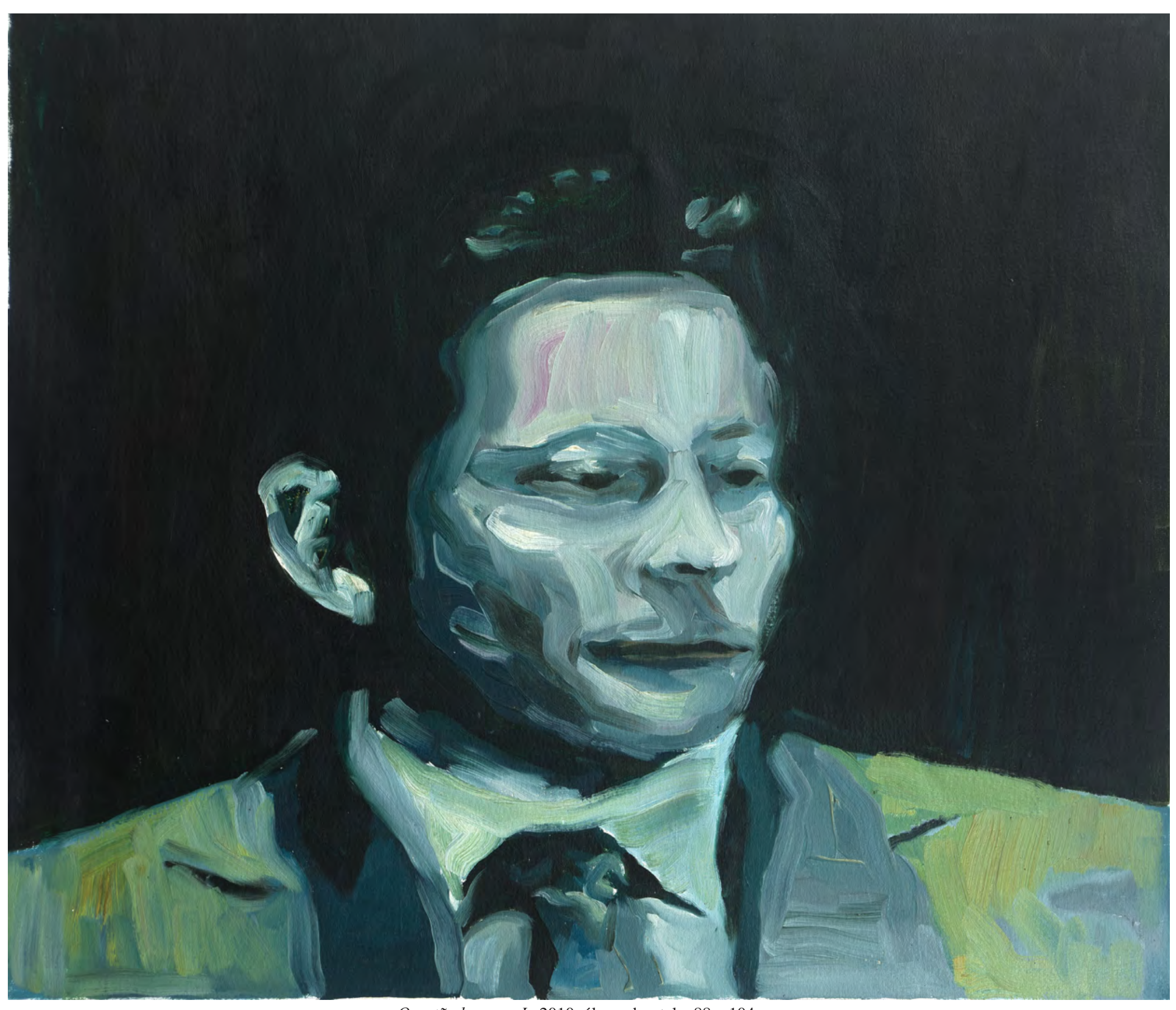

Questão humana I, 2010, óleo sobre tela, 88 x 104 cm 


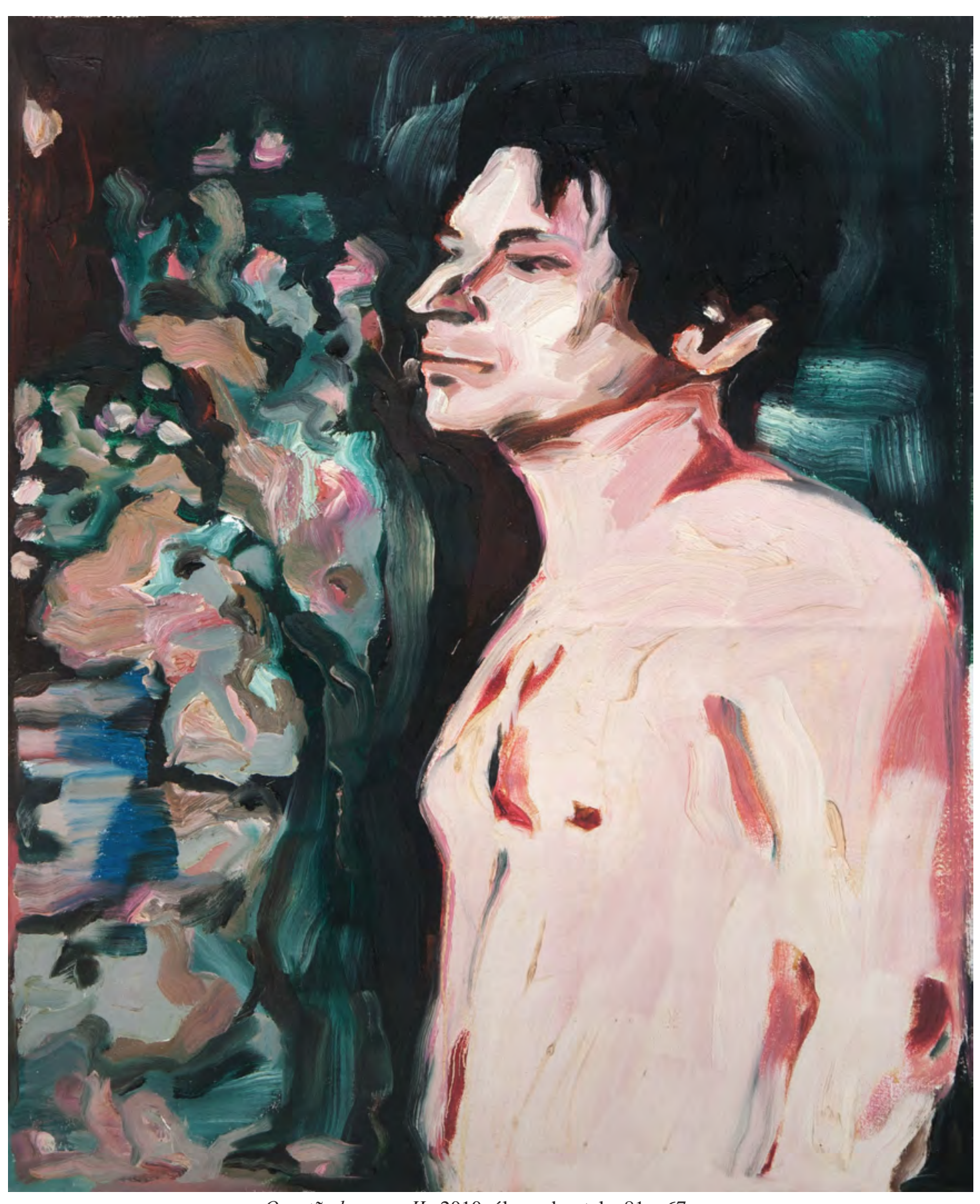

Questão humana II, 2010, óleo sobre tela, 81 x 67 cm

$\theta$ 


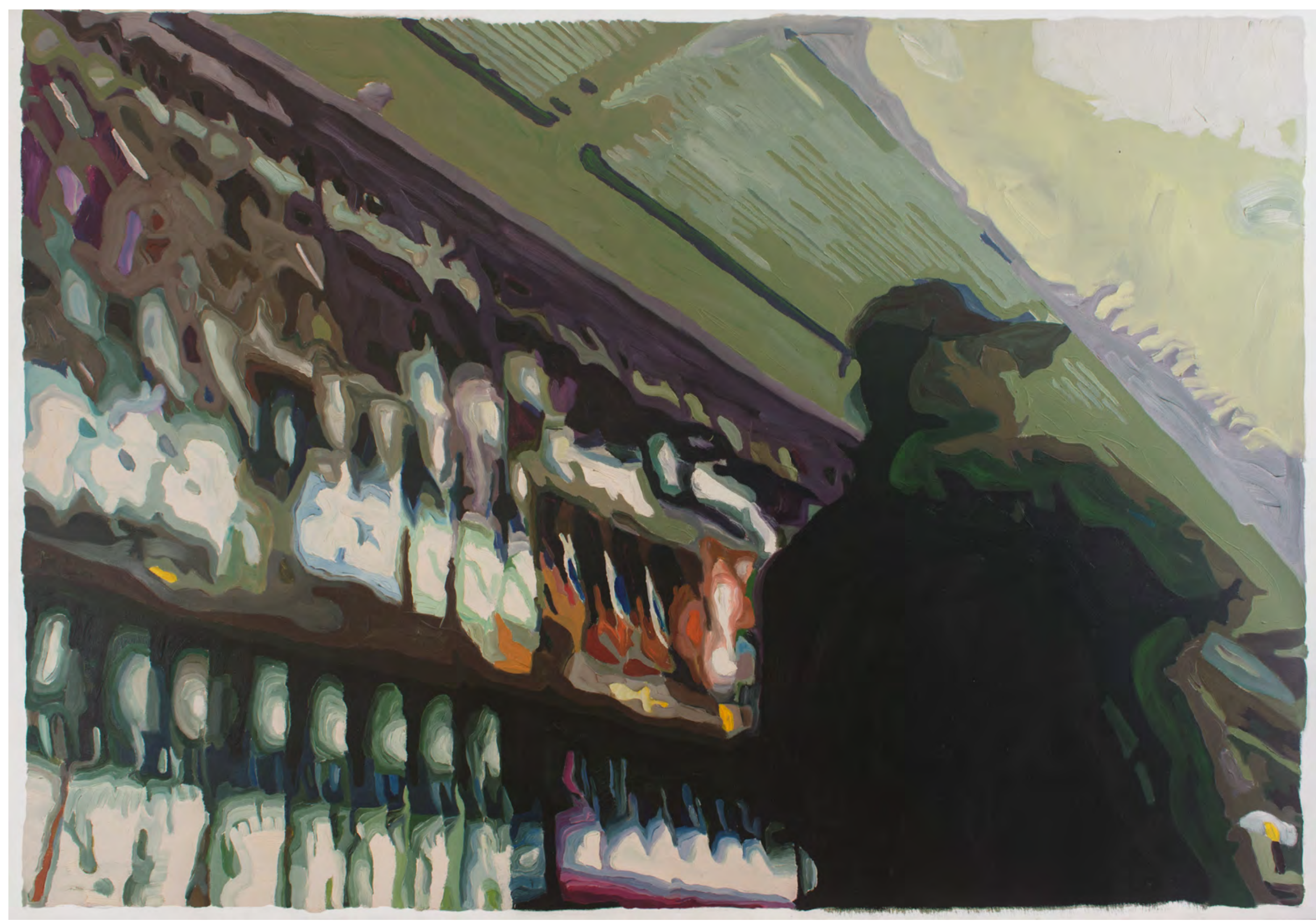

Homem no mercado, 2013, óleo sobre tela, 134 x 190 cm 


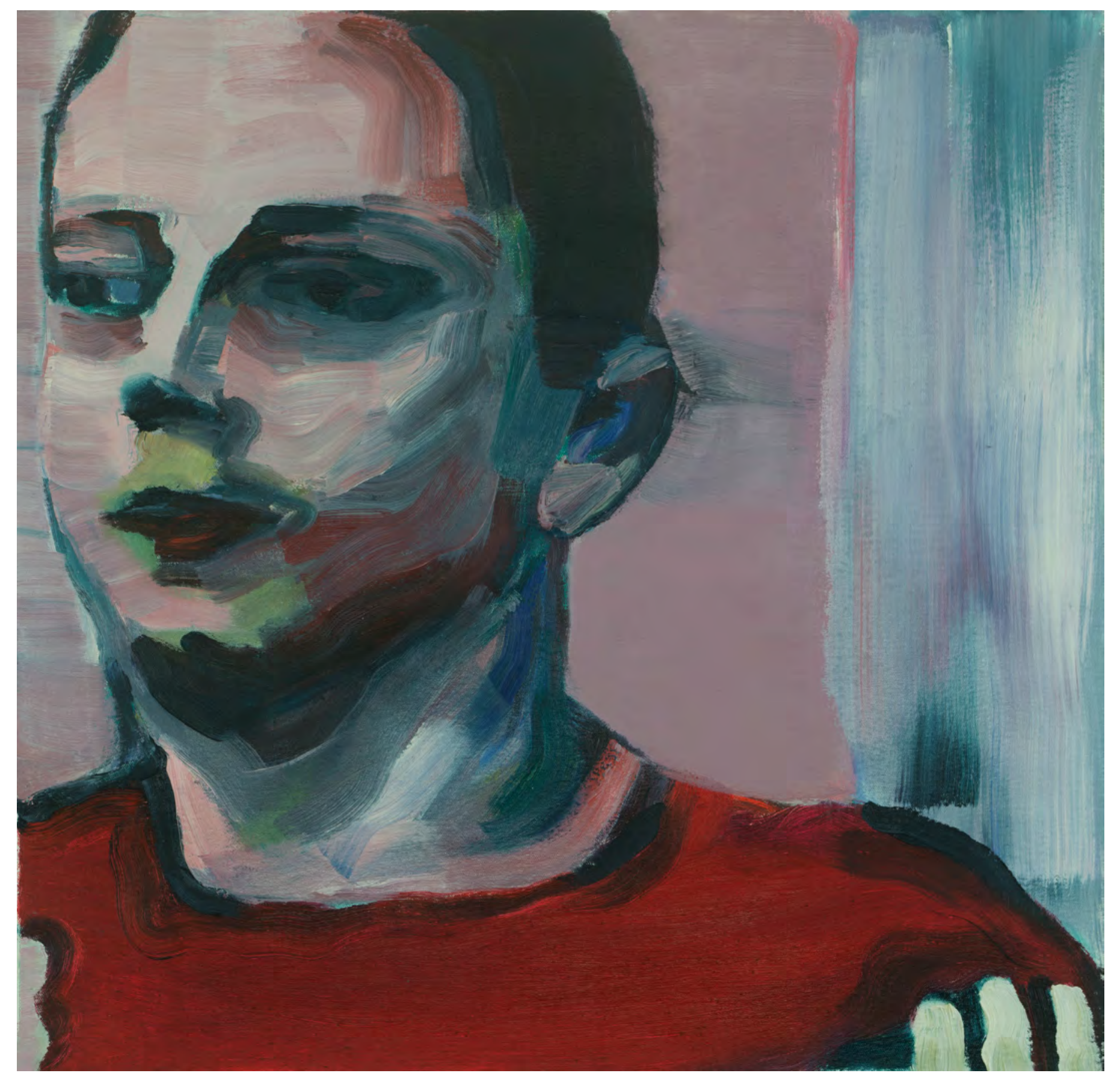

(4)

Vermelho, 2014, óleo sobre tela, 61x 62 cm 


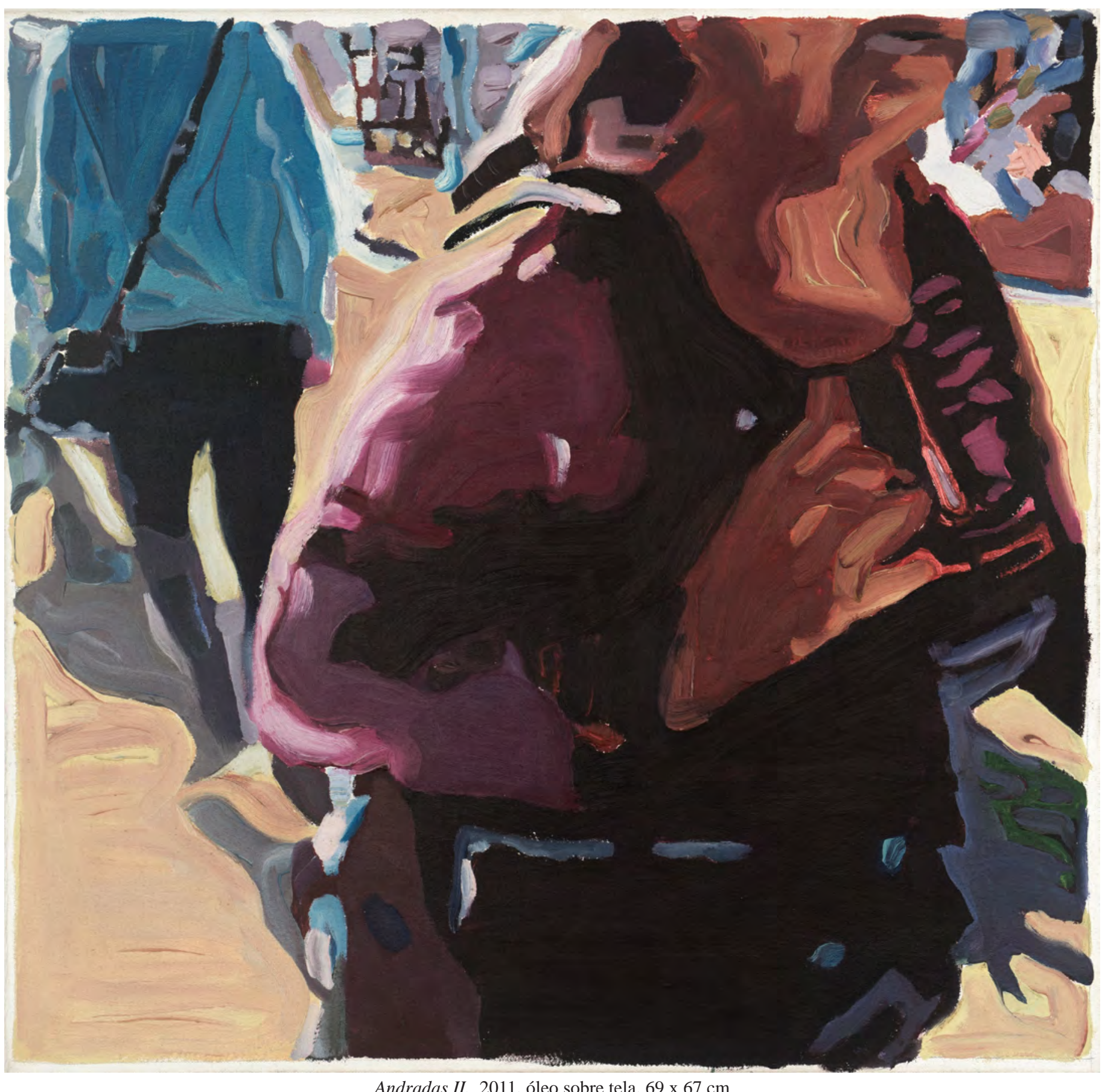

Andradas II, 2011, óleo sobre tela, 69 x 67 cm 


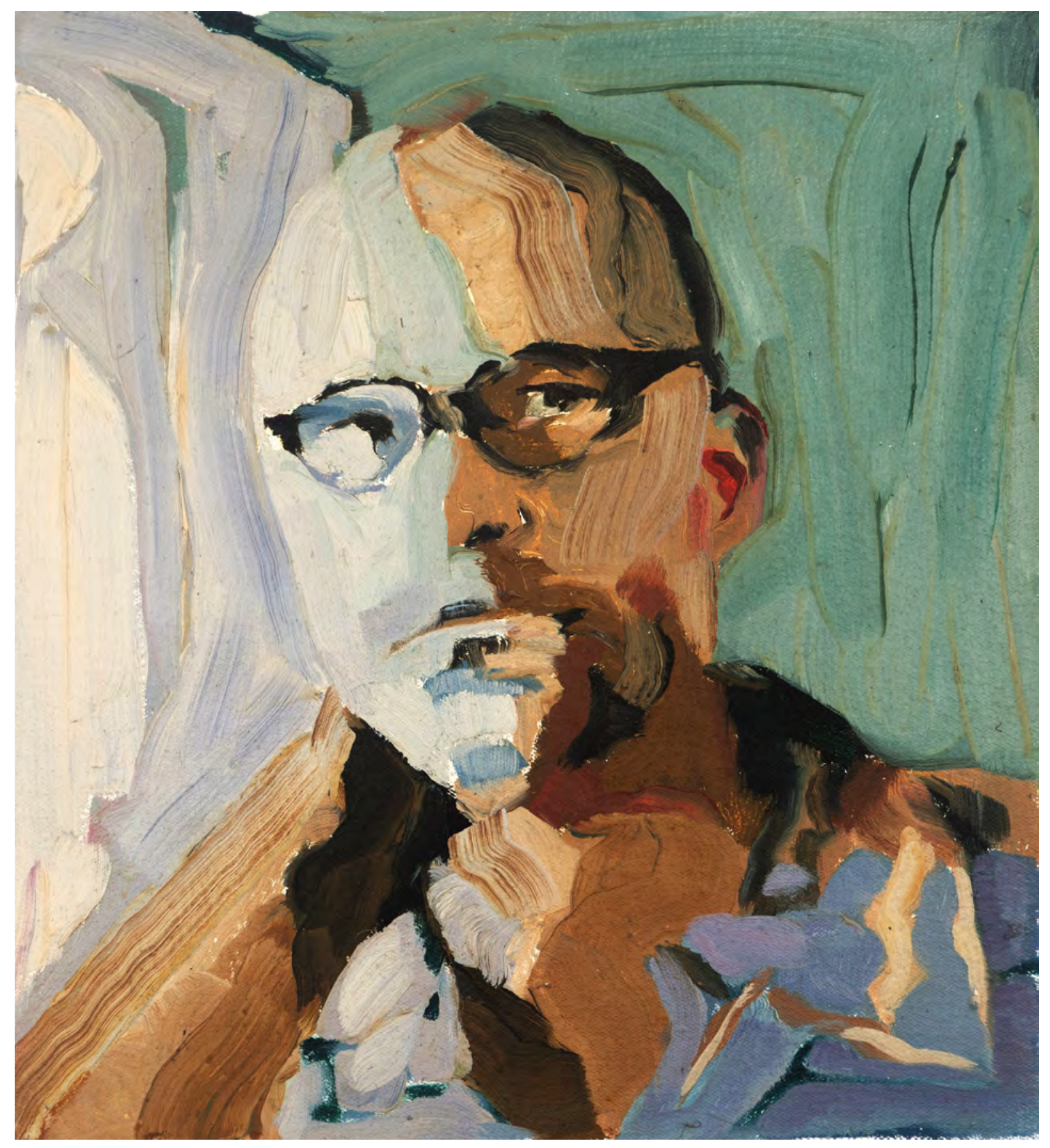

Gil, 2011, óleo sobre tela, 38 x 35 cm

$\theta$ 


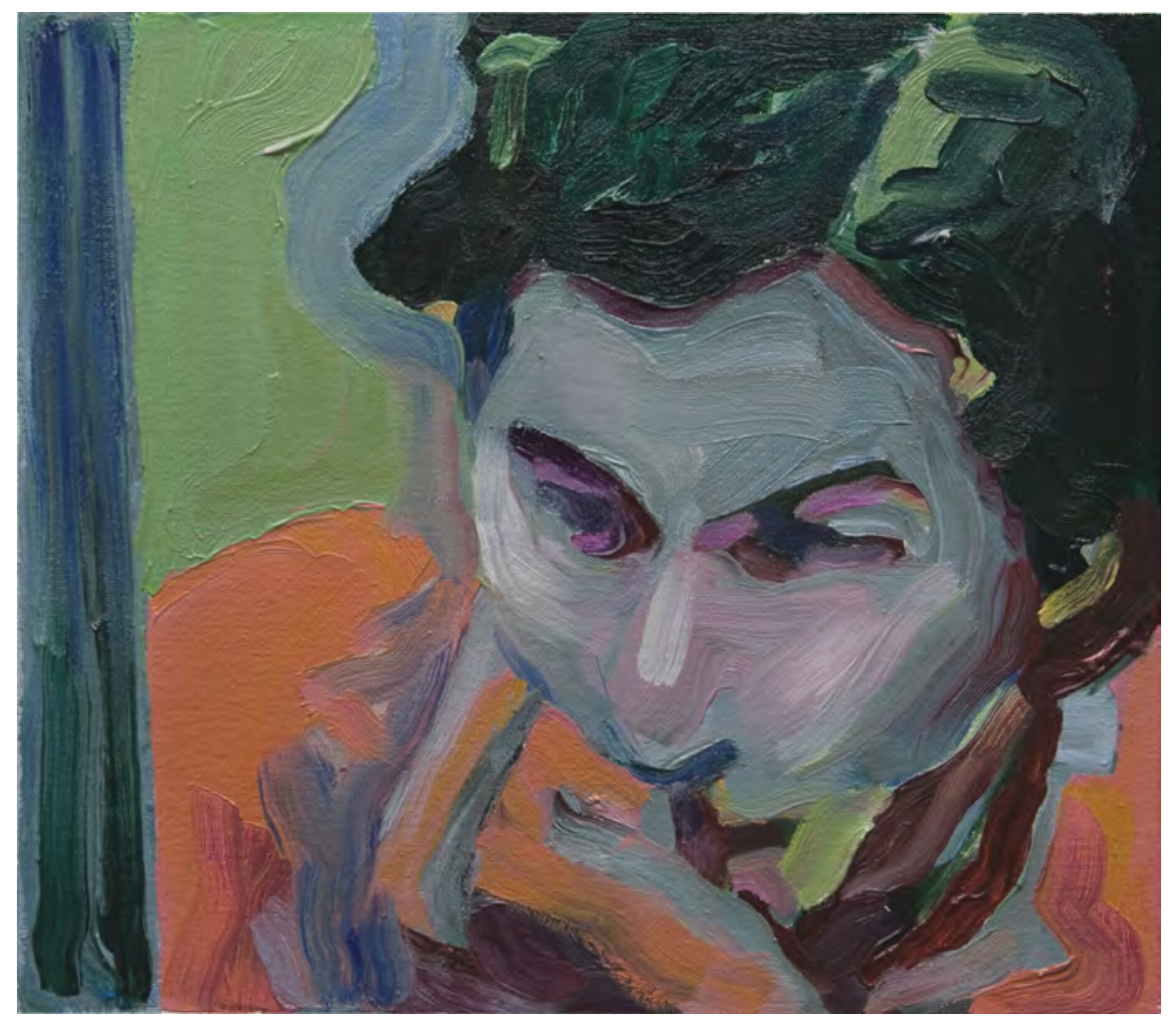

O pensador no metro, 2011, óleo sobre tela, 35 x $40 \mathrm{~cm}$

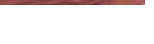

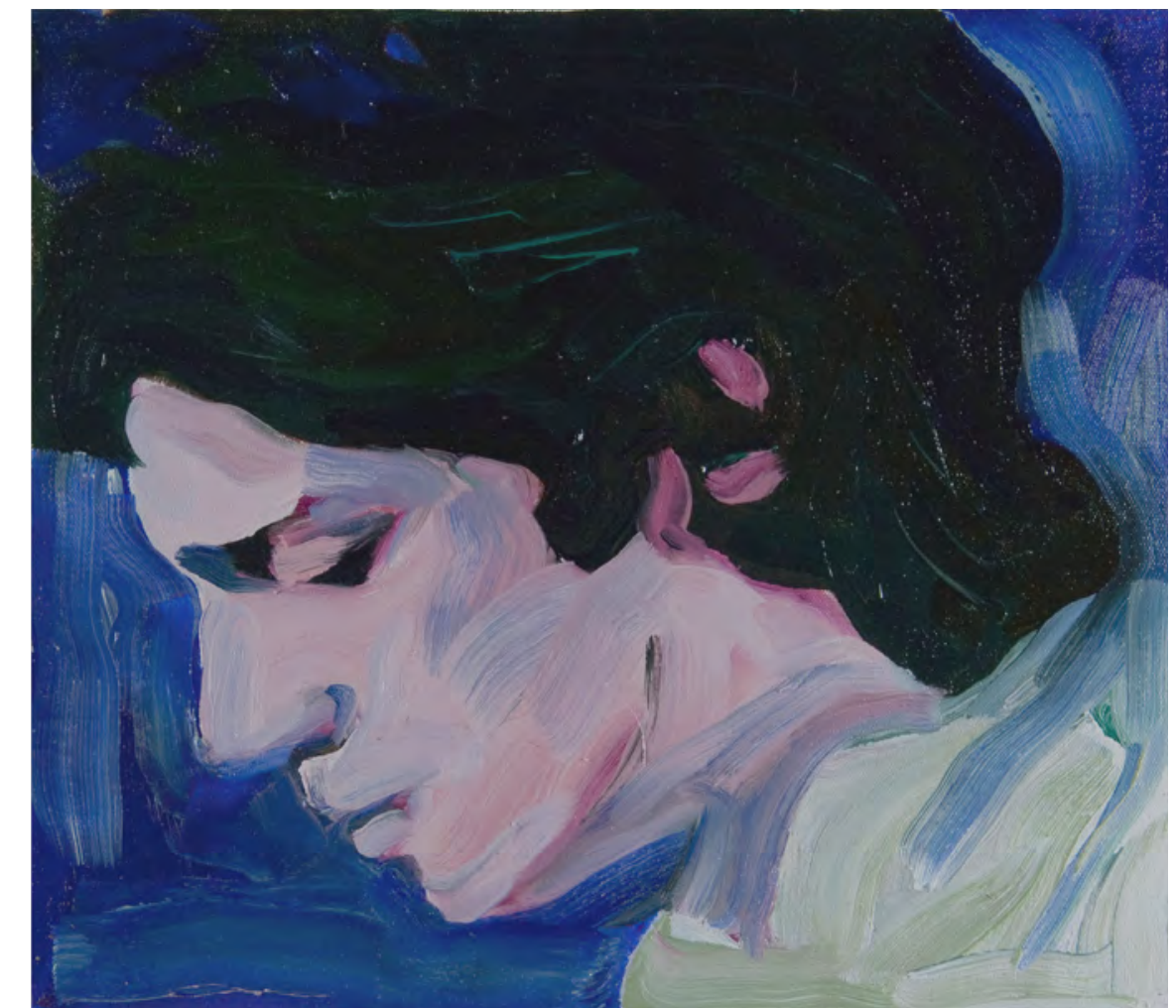

O francês, 2011, óleo sobre tela, 35 x $40 \mathrm{~cm}$
(4) $\oplus$ 


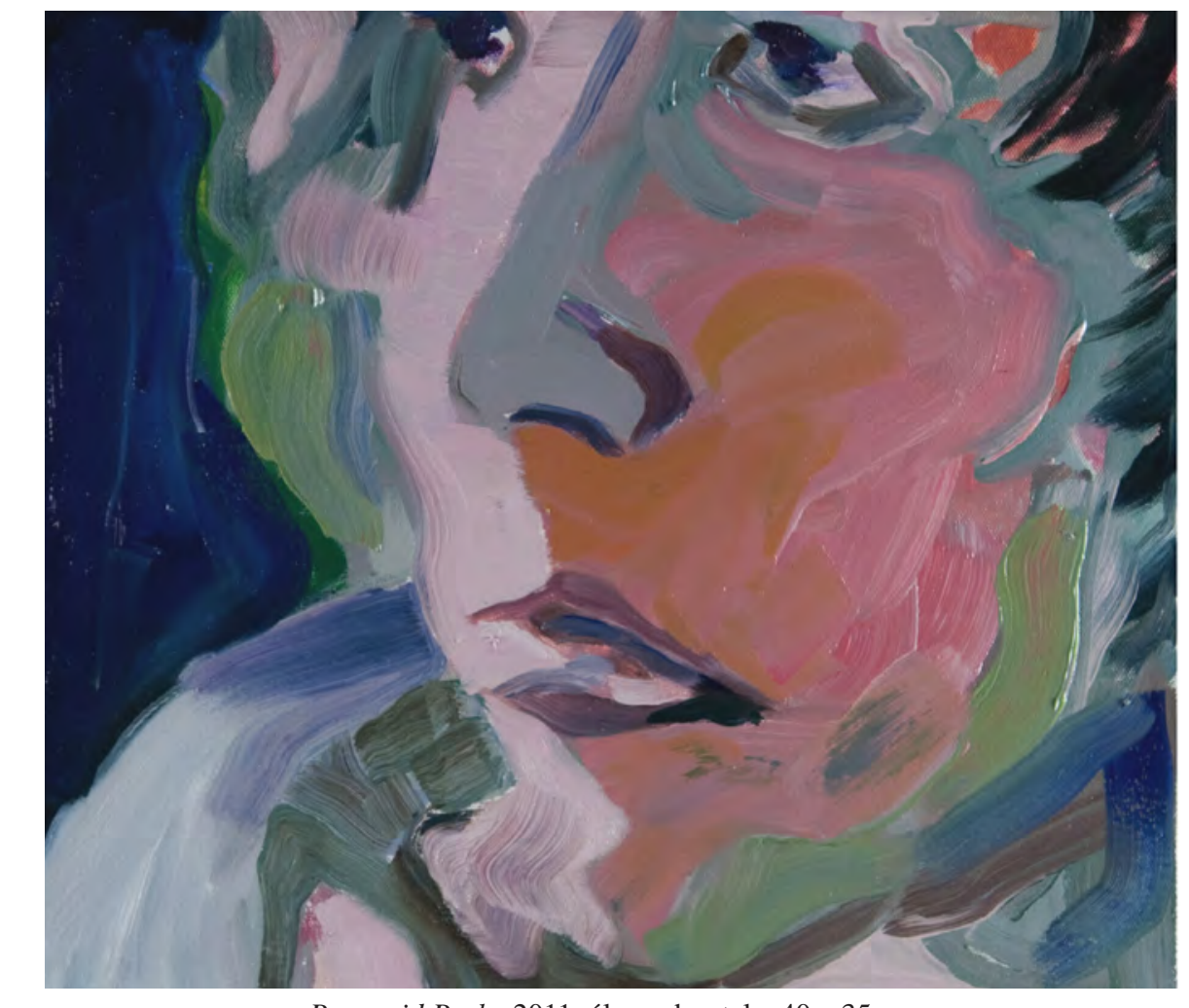

Paranoid Park, 2011, óleo sobre tela, 40 x 35 cm 


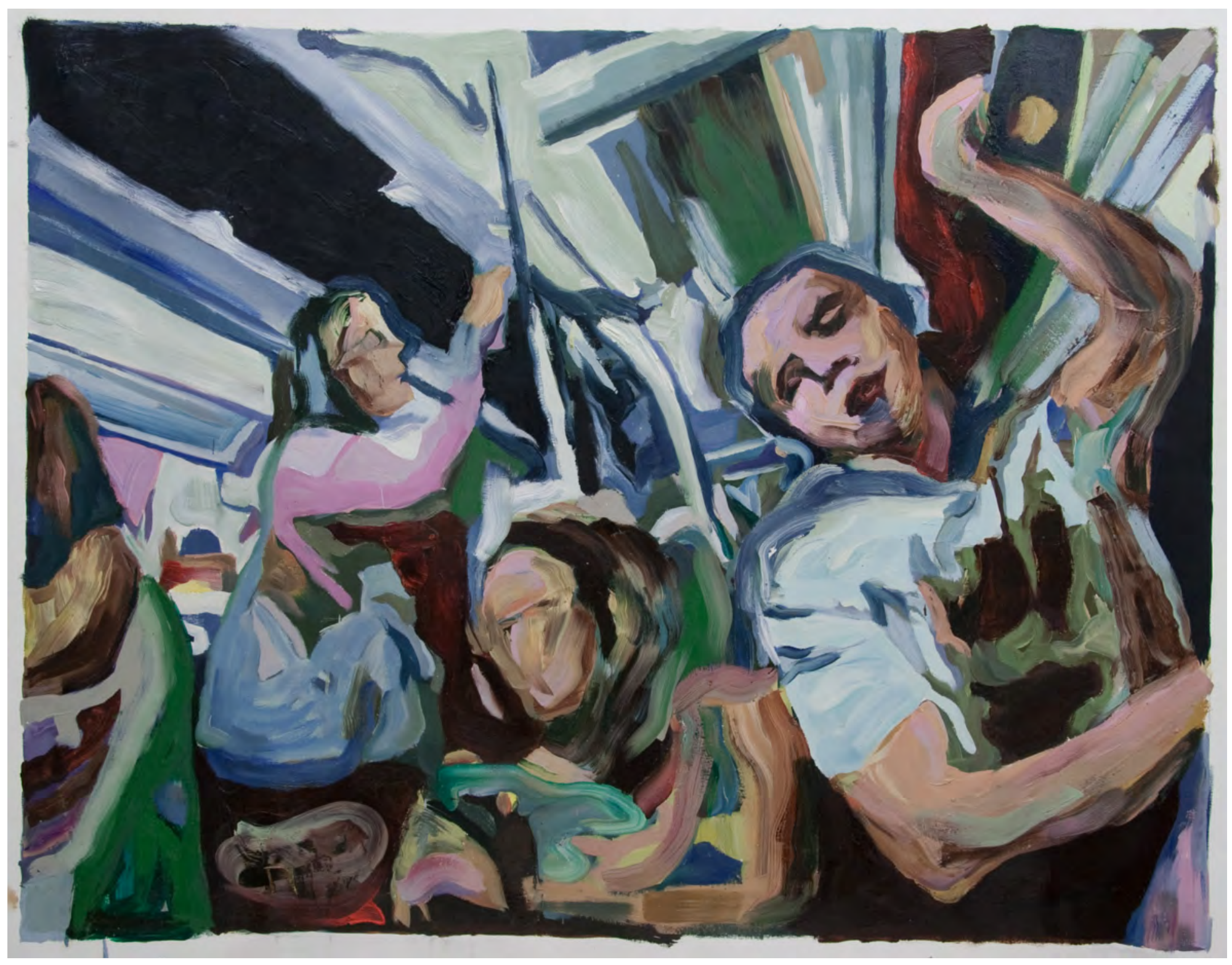

Figuras no metrô, 2011, óleo sobre tela, 50 x 62 cm 


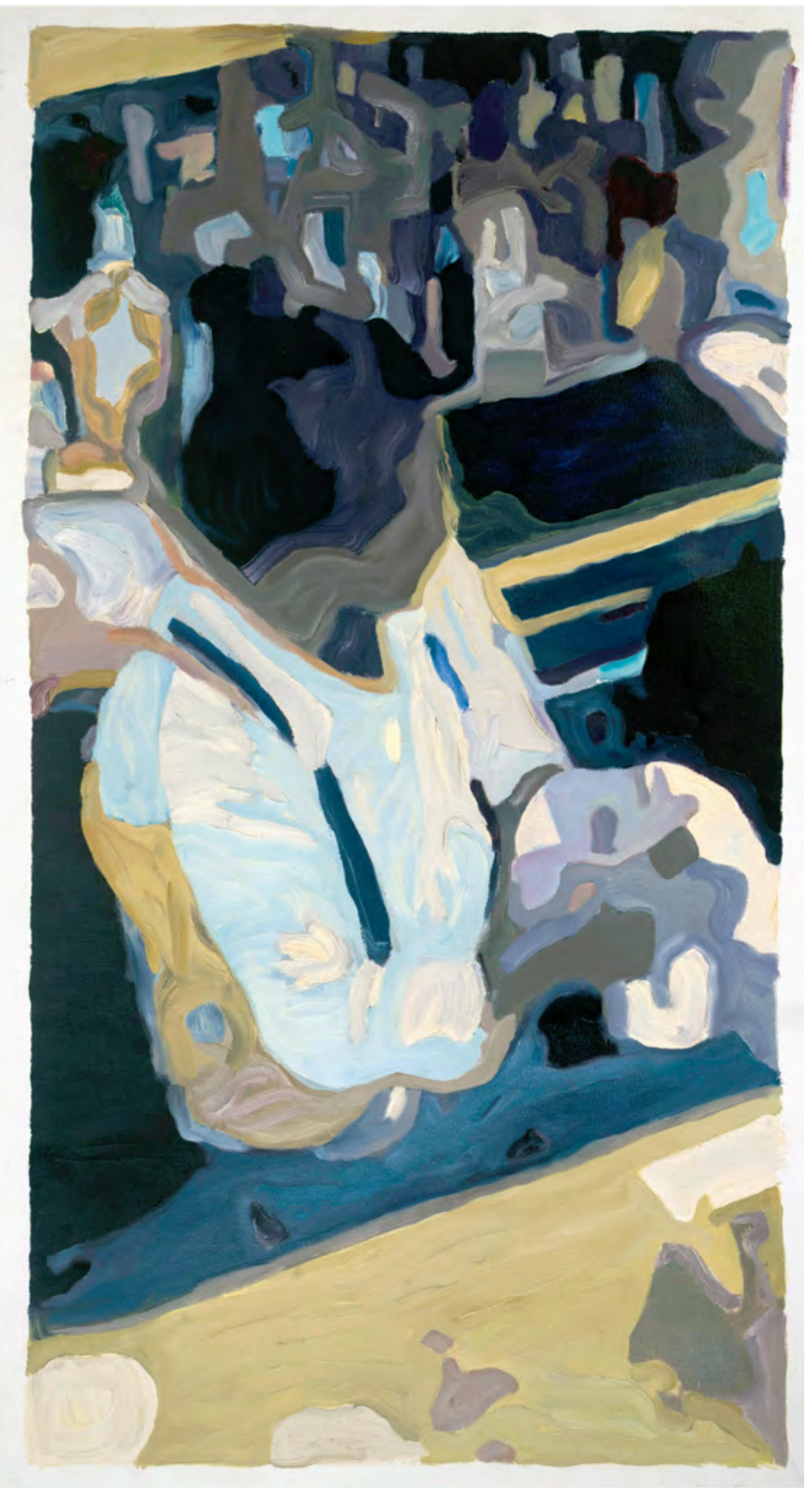

Lavando pratos, 2011, óleo sobre tela, 171 x 45 cm 



\section{REFERÊNCIAS BIBLIOGRÁFICAS}


ADE, Peter A. (org.) Munch und Deutschland. Catálogo. Sttutgart: Verlag Gerd Hatje, 1994.

ANFAM, David. Abstract Expressionism. London: Thames \& Hudson, 1990. ARGAN, G.C. Arte Moderna. São Paulo: Companhia das Letras, 1992.

ARGAN, G.C. História da arte como história da cidade. São Paulo: Martins Fontes, 2005.

ASHTON, Dore. About Rothko. Cambridge: Da Capo, 2003.

AUMONT, Jacques. O olho interminável [cinema e pintura]. São Paulo: Cosac \& Naify, 2004.

BACHELARD, Gaston. A intuição do instante. Verus Editora, 2007. A Poética do devaneio. São Paulo: Editora WMF

Martins Fontes, 2009.

BAUDELAIRE, Charles. Sobre a modernidade: o pintor da vida moderna./ Teixeira Coelho(org.). Rio de Janeiro: Paz e Terra, 1996.

BARTHES, Roland. A câmara clara. Lisboa: Edições 70, 1980.

Mitologias. São Paulo: Difusão Europeia do Livro,

1972.

BENJAMIN, Walter. A modernidade e os modernos. Rio de Janeiro: Tempo Brasileiro, 1975.

BERMAN, Marshall. Tudo o que é sólido desmancha no ar. A aventura da modernidade. São Paulo: Companhia das Letras, 1986.

BRANDÃO, Junito de Souza. Mitologia Grega, volume I. Rio de Janeiro: Ed.

Vozes, 1986. 
BRESLIN, James E. B..Mark Rothko: a biography. London: The University of Chicago Press, 1993.

CALVINO, Italo. Seis propostas para o próximo milênio. Companhia da Letras, 1990

CAMARGO, Iberê. Gaveta dos guardados. São Paulo: EDUSP, 1998.

CAUQUELIN, Anne. Freqüentar os incorporais: contribuição a uma teoria da arte contemporânea. São Paulo: Martins, 2008.

CLARK, T.J. Modernismos: ensaios sobre política, história e teoria da arte./ Sônia Salzstein (org), São Paulo: Cosac \& Naify, 2007.

DANTO, Arthur C. Aprendendo a viver com o pluralismo. In: Revista Valise, Porto Alegre, v.1, n. 2, ano 1, dez. 2011. Tradução Daniela Kern.

DELEUZE, Gilles. Francis Bacon: Lógica da Sensação. Rio de Janeiro: Jorge Zahar Ed., 2007.

DERRIDA, Jacques. The truth in painting. The University of Chicago Press, 1987.

DIDI-HUBERMAN, Georges. A Pintura Encarnada. São Paulo: Escuta, 2012. EISENSTEIN, Sergei M.. Piranesi, or the fluidity of forms. In: TAFURI, Manfredo. The sphere and the labyrinth. Avant-Gardes and Architecture from Piranesi to the 1970`s. MitPress, 1990.

FERREIRA, Glória; COTRIM, Cecilia (org.) Escritos de artistas: anos 60/70. Rio de Janeiro: Jorge Zahar Ed. 2006.

FOUCAULT, Michel, Ditos e Escritos - vol. III - Estética: Literatura e Pintura, Música e Cinema. Manoel Barros da Motta (org.). Rio de Janeiro: Forense Universitária, 2009. 
A palavra e as coisas. Uma arqueologia das ciências humanas. São Paulo: Martins Fontes, 2000.

FRIED, M. Absorption and Theatricality: Painting and Beholder in the Age of the Diderot. Chicago: The Inuversity of Chicago Press, 1980.

GENET, Jean. Rembrandt. Rio de Janeiro: José Olympio, 2002.

O ateliê de Giacometti. São Paulo: Cosac \& Naify, 2001.

GINZBURG, Carlo. Mitos, emblemas, sinais: morfologia e historia. São Paulo: Companhia das Letras, 1989.

GODFREY, Tony. Painting Today. New York: Phaidon Press Limited, 2009.

GONZALES FLORES, Laura. Fotografia e pintura: dois meios diferentes? São Paulo: Ed. WMF Martins Fontes, 2001.

GREENBERG, Clement. Pintura Modernista. In: FERREIRA, Glória; COTRIM, Cecília (org.). Clement Greenberg e o Debate Crítico. Rio de Janeiro: Funarte Jorge Zahar, 1997.

HUGHES, Robert. Lucian Freud paintings. London: Thames \& Hudson, 2008.

LICHTENSTEIN, Jacqueline (org.) A pintura - Vol.6: A figura humana. São Paulo: Ed. 34, 2005.

LONGHI, Roberto. Piero della Francesca. São Paulo: Cosac \& Naify, 2007. Breve mas verídica história da pintura italiana. São Pau-

lo: Cosac Naify, 2005.

LOOCK, Ulrich. Luc Tuymans. London: Phaidon Press, 2003. 
NOVAES, Adauto (org.) O Homem-Máquina: a ciência manipula o corpo. São Paulo: Companhia das Letras, 2003.

O’DOHERTY, Brian. American Masters. New York: E.P. Dutton, 1982.

PAZ, Otávio. Marcel Duchamp ou o castelo da pureza. São Paulo: Perspectiva, 1990

PASTA, Paulo. A educação pela pintura. São Paulo: Editora WMF Martins Fontes, 2012.

PEDROSA, Mario. Acadêmicos e modernos: textos escolhidos III. Otília Arantes (org.). São Paulo: Editora da Universidade de São Paulo, 2004.

RANCIÈRE, Jacques. O mestre ignorante. Cinco lições sobre a emancipação intelectual. Belo Horizonte: Autêntica, 2002.

ROSENBERG, Harold. O objeto ansioso. São Paulo: Cosac \& Naify, 2004.

SALZSTEIN, Sônia. Diálogos com Iberê Camargo. São Paulo: Cosac \& Naify, 2003.

SANTO AGOSTINHO. Confissões. Coleção: Os Pensadores. São Paulo: Editora Nova Cultural, 1999.

SCHAPIRO, Meyer. A unidade da arte de Picasso. São Paulo: Cosac \& Naify, 2002.

SONTAG, Susan. Ensaios sobre a fotografia. Rio de Janeiro: Editora Arbor, 1981. 
STILES, K e SELZ, P (org.). Theories and Documents of Contemporary Art: A sourcebook of Artists Writings. Los Angeles: Univ. of Calif. Press, 1996.

STOR, Robert e RICHTER Gerhard. Forty Years of Painting. Publisher: The Museum of Modern Art, New York, 2002.

STOR, Robert. Doubt and Belief in Painting. New York: The Museum of Mo-dern Art, 2003.

STEINBERG, Leo. Outros Critérios. In: In: FERREIRA, Glória; COTRIM, Cecília (org.). Clement Greenberg e o Debate Crítico. Rio de Janeiro: Funarte Jorge Zahar, 1997.

SYLVESTER, David. Um olhar sobre Giacometti. São Paulo: Cosac \& Naify, 2012. THOMPSON, Jerry L. Walker Evans at work. London: Thames and Hudson, 1994. VALÉRY, Paul. Introdução ao método de Leonardo da Vinci. São Paulo: Editora $34,2006$.

VENÂNCIO FILHO, Paulo. Marcel Duchamp. A beleza da indiferença. São Paulo: Brasiliense, 1986.

VAN DEN BOOGERD. Dominic, BLOOM, Barbara e CASADIO, Mariuccia. Marlene Dumas. London: Phaidon Press, 1999, p.116.

VENTURI, Lionello. Para compreender a pintura: De Giotto a Chagall. Lisboa: Editorial Estúdios Cor, 1968.

WOLLHEIM, Richard. A pintura como arte. São Paulo: Cosac \& Naify, 2002.

WYSS, Beat. Der Wille zur Kunst: zur ästhetischen Mentalität der Moderne. Koln: DuMont, 1996. 
